UNIVERSIDADE DE SÃO PAULO

FACULDADE DE FILOSOFIA, LETRAS E CIÊNCIAS HUMANAS

DEPARTAMENTO DE LINGUÍSTICA

PROGRAMA DE PÓS-GRADUAÇÃO EM SEMIÓTICA E LINGUÍSTICA GERAL

ALEXANDRE FELIPE DE SOUSA

A manutenção do individualismo e a mão invisível: uma abordagem semiótica em Adam Smith

São Paulo

2019

(versão corrigida) 


\author{
UNIVERSIDADE DE SÃO PAULO \\ FACULDADE DE FILOSOFIA, LETRAS E CIÊNCIAS HUMANAS \\ DEPARTAMENTO DE LINGUÍSTICA \\ PROGRAMA DE PÓS-GRADUAÇÃO EM SEMIÓTICA E LINGUÍSTICA GERAL
}

\title{
A manutenção do individualismo e a mão invisível: uma abordagem semiótica em Adam Smith
}

\section{Versão Corrigida}

Alexandre Felipe de Sousa

Dissertação apresentada à Faculdade de Filosofia, Letras e Ciências Humanas da Universidade de São Paulo para a obtenção do título de Mestre em Linguística.

Área de Concentração: Semiótica e Linguística Geral.

Orientador: Prof. Dr. Waldir Beividas 
Autorizo a reprodução e divulgação total ou parcial deste trabalho, por qualquer meio convencional ou eletrônico, para fins de estudo e pesquisa, desde que citada a fonte.

Catalogação na Publicação

Serviço de Biblioteca e Documentação

Faculdade de Filosofia, Letras e Ciências Humanas da Universidade de São Paulo

Sousa, Alexandre Felipe

$\mathrm{S} 725 \mathrm{~m}$

A manutenção do individualismo e a mão invisível: uma abordagem semiótica em Adam Smith / Alexandre

Felipe Sousa ; orientador Waldir Beividas. - São

Paulo, 2019.

$100 \mathrm{f}$.

Dissertação (Mestrado)- Faculdade de Filosofia, Letras e Ciências Humanas da Universidade de São Paulo. Departamento de Linguística. Área de concentração: Semiótica e Lingüística Geral.

1. Semiótica. 2. Economia. 3. Discurso. 4. Manipulação. 5. Adam Smith . I. Beividas, Waldir, orient. II. Título. 


\section{ENTREGA DO EXEMPLAR CORRIGIDO DA DISSERTACÃO/TESE}

\section{$\underline{\text { Termo de Ciência e Concordância do (a) orientador (a) }}$}

Nome do (a) aluno (a): Alexandre Felipe de Sousa

Data da defesa: 16/12/2019

Nome do Prof. (a) orientador (a): Waldir Beividas

Nos termos da legislação vigente, declaro ESTAR CIENTE do conteúdo deste EXEMPLAR CORRIGIDO elaborado em atenção às sugestões dos membros da comissão Julgadora na sessão de defesa do trabalho, manifestando-me plenamente favorável ao seu encaminhamento e publicação no Portal Digital de Teses da USP.

São Paulo, 21 / 01 / 2020

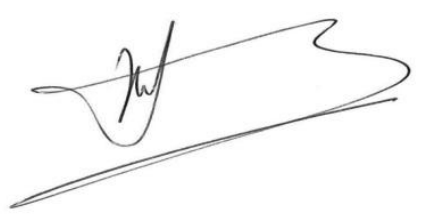

(Assinatura do (a) orientador (a) 
Nome: Alexandre Felipe de Sousa

Título:

Dissertação apresentada à Faculdade de Filosofia, Letras e Ciências Humanas da Universidade de São Paulo para a obtenção do título de Mestre em Linguística.

Programa de Pós Graduação em Semiótica e Linguísitca Geral.

Aprovado em:

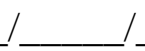

Banca Examinadora

Prof. Dr.:

Instituição:

Julgamento:

Profa. Dra.:

Instituição:

Julgamento:

Prof. Dr.:

Instituição:

Julgamento:

Profa. Dra.:

Instituição:

Julgamento: 
Em memória dos que se foram, em homenagem aos que estão e com carinho a que vem. 


\section{AGRADECIMENTOS}

A elaboração da presente dissertação foi possível, sobretudo, graças ao apoio financeiro da CAPES, pela concessão de bolsa e pontualidade nos depósitos. As opiniões, hipóteses e conclusões ou recomendações expressas neste material são de responsabilidade do autor, não necessariamente refletem a visão da CAPES.

Ao professor-orientador Dr. Waldir Beividas, que desde a então disciplina de semiótica na graduação em 2011 se me apresentou como um Destinador manipulador que, à parte de sua graciosidade nas análises e na própria epistemologia da teoria, acolheu-me na I.C., e sempre me ajudou na dupla jornada academia e escola pública, ora dando um testemunho em plataformas de ensino, ora assinando cartas de recomendação, entendendo sempre minhas necessidades como trabalhador e estudante. Mestre, de coração, obrigado.

A Paula, que naqueles mesmos idos de 2011 a meados de 2015 fora a coDestinadora designada e encarregada de me fazer-saber. Que paciência e dedicação teve para acolher-me nas aulas, encontros, e para receber e-mails com dúvidas triviais aos sábados à tarde e comprometimento e atenção para me responder com o dobro de páginas nos domingos pela manhã. Mestra, Danke sehr.

Ao Marcos Lopes, que se tornou para mim professor modelo de seriedade, comprometimento com o saber e postura em sala. Sua generosidade no convite ao gabinete em 2009 para me guiar e orientar pós nota 3 na prova de Elementos para sempre será lembrada.

A Carol Tomasi, pela sua também paciência em me atender e tirar dúvidas sobre semiótica e pela dedicatória no autógrafo.

Ao Ivã Lopes, pelos poucos, porém preciosos e inesquecíveis momentos que me cedeu sua atenção, seu sorriso e suas tiradas cômicas nas reuniões do Labores. Espero que ele não pare. 
A Altman por apresentar os estudos em tópicos de historiografia, filosofia da linguagem e epistemologia, sobretudo nesse último, pois Popper, Kuhn, "Searle" e Laudan ainda me afetam.

A todos os membros que ainda estão e que passaram nesses oito anos de Labores, Thiago, Daniel, Shimoda, Júlio, Júlia, Eliane, Guilherme, Ana, e tantos outros mais. Direta ou indiretamente foram fundamentais para meu aprendizado.

À banca avaliadora, em 2017, por ter acreditado na pertinência do projeto de pesquisa para aceitação e, não apenas, para a obtenção de bolsa.

À minha irmã Clarice, sem a qual não daria para passar a vida, tanto por sempre ter sido uma Dona Irene para mim, quanto pelo bolo prestígio com ingrediente de carinho nos meses de Novembro.

Ao meu irmão Sergio pelo apoio, pela mão generosa que sempre me estendeu na vida e pelo sorriso corinthiano que nunca lhe faltou a mim.

A todos os alunos, sem exceção, da E.E. Prof. José Jorge, E.E. Mjr. Telmo Coelho Filho, E.E. Prof. José Maria Perez Ferreira, E.E. Dep. Derville Allegretti, Cursinho Popular de Jandira, E.E.F.M.T. Prof ${ }^{a}$. Dagmar Ribas Trindade, ITB Prof ${ }^{a}$. Maria Sylvia Chaluppe Mello, E.M.E.I.E.F. Dorival Faria e Preparatório Enem de Itapevi. Sem vocês não seria possível continuar realizando meu sonho.

A todos aqueles que comigo atuaram e atuam seriamente nessa missão que é, para mim, a mais importante de um país: ser professor.

À professora Márcia do Dag, por se envolver comigo com a razão e o coração nos projetos de redação.

Ao professor, militante da educação, publicitário artista plástico encantador, Chico Barbosa, pelas longas horas de papo sobre a educação do país, na companhia de cerveja, João Nogueira, Chico Buarque e amendoim. 
Aos diretores, administração e gestão pedagógica de todas as unidades escolares acima mencionados que muito me ensinaram e em mim acreditaram, com atenção especial aos diretores, vice e coordenadores Priscila, Fernando e Marina.

Aos amigos preciosos que me aturam e acompanham desde a década de 90, nos fliperamas, nas madrugadas de jogatina de videogame, nos churrascos e nas horas mais difíceis da minha vida: Doriel, Fran, Chang, Leandro, Mark e Nenê. Vocês são uma boa parte do que sou. Obrigado, brothers.

Ao grupo de RPG: porque a vida sem interpretação, ficção e dados seria uma realidade muito chata.

À secretaria de Pós em Linguística da USP.

Às comissões organizadoras dos Enapois que assisti e trabalhei.

À FFLCH, à USP e a todos os envolvidos na administração da infraestrutura e dos programas de cultura e extensão oferecidos nesses meus 11 anos de instituição.

Ao operador do trem da CPTM, aos inspetores escolares, ao servente de pedreiro, ao caixa de supermercado, ao conferente, atendente da rede de fast-food, ao agente de saneamento que recolhe o lixo semanalmente na porta de casa, e a todos os demais trabalhadores que compõem a sociedade e optam por uma vida honesta, mas ainda assim sofrem com tantos problemas sociopolíticos do país.

Agradecer especialmente a Adriana, que desde o primeiro semestre de Letras, naquelas aulas de Introdução à Literatura, me acompanha, me ajuda e me ama com os cafés, as conversas, suas aulas sobre Heródoto e a torta de morango. Sem você, não haveria sentido.

À Dona Irene e ao Sr. Tiburcio. 

Uma teoria deve parecer melhor que suas competidoras, mas não precisa (e de fato isso nunca acontece) explicar todos os fatos com os quais pode ser confrontada.

(Thomas Khun) 


\section{RESUMO:}

A pesquisa em semiótica francesa se mostra cada vez mais profícua para a análise de textos que saem do meio ficcional "verbal-escrito" (literatura, conto, poesia, etc.), expandindo-se às demais áreas do conhecimento, como as ciências naturais e seus discursos, e aos gêneros com plano de expressão mais complexos, como cinema, história em quadrinhos, etc. Diante disso, este trabalho tem por objetivo aplicar essa metodologia de análise sobre a obra de teoria econômica A Riqueza das Nações ([1776]1996), de Adam Smith, visando examinar as noções de "individualismo", a "mão invisível”, bem como suas diversas relações actanciais entre Destinador e Destinatário/sujeito, bem como entender melhor a maneira discursiva na qual se manifesta e do papel da economia na nos processos contraídos entre sujeitos. Segundo o próprio Smith, a divisão do trabalho (DIT) pretende potencializar a força de trabalho em vários sujeitos sob o pretexto de uma efetividade na produção e, consequentemente, no seu sucesso, leia-se, o alcance aos objetos visados. Eis então uma configuração narrativa subjacente ao texto, em que o Destinador-manipulador estabelece um contrato com seus Destinatários a fim de torná-los sujeitos obviamente em relação com seu objeto, do próprio Destinador. Além disso, há em nível discursivo, na manta superficial do texto, a ideia de que o interesse subjaz todas as práticas impressas no discurso smithiano, do investidor ao trabalhador, do trabalhador ao senhor de terra, configurando assim a força motriz nuclear dos fazeres de uma nação.

Palavras-Chaves: semiótica, economia, discurso, manipulação, Adam Smith 


\begin{abstract}
The research into french semiotics increasingly shows analyzes of texts that are half-verbal (writing, verbal, writing, poetry, etc.) and it is expanded to other areas of knowledge, such as the natural sciences and their discourses, and genres with more complex expression plan, such as cinema, comics, etc.

Before that, this paper aims to apply this methodology of analysis on the work of economic theory The Wealth of Nations, by Adam Smith, aiming to examine the "individualism", the invisible hand and its various actancial relations between Addresser-Addressee / subject, as well as better understand the discursive way about the value of labor and the role of the economy in the contracted processes between subjects.

According to A. Smith himself, the division of labor intends to enhance the workforce in various subjects under the pretext of an effectiveness in production and, consequently, in its success - read, the reach to objects.

Here is then a narrative configuration underlying the text, in which the Addressermanipulator establishes a contract with his Adressee in order to manipulate him obviously into his object, and the one Destinator himself.

Besides that, there is at the discursive level, in the superficial stratum of the text, the idea that interest underlies all practices printed in the Smithian discourse, from investor to worker, from worker to landlord, thus shaping the nuclear driving force of nations.
\end{abstract}

Keywords: semiotic, economy, speech, manipulation, Adam Smith 


\section{SUMÁRIO}

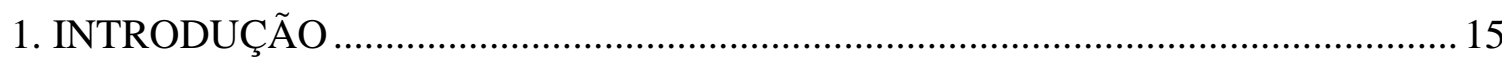

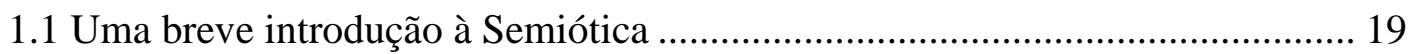

1.1.1 O percurso gerativo greimasiano de sentido e sua contribuição para o "ser" da análise: nível narrativo, fundamental e discursivo. ...................................................21

1.2 Uma breve introdução à economia................................................................... 24

1.2.1 Uma breve introdução a Adam Smith e sua investigação sobre a natureza e as causas de A Riqueza Das Nações ........................................................................2 27

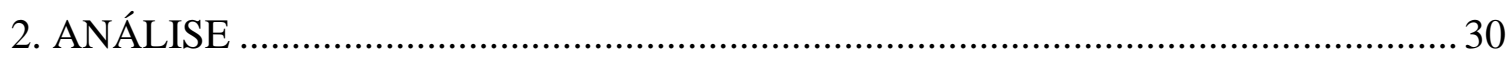

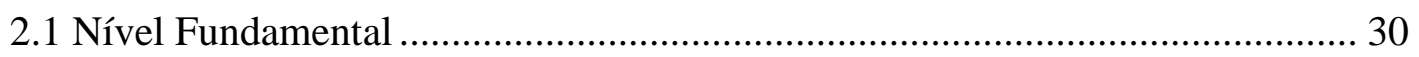

2.1.1 O quadrado semiótico em A Riqueza das Nações .............................................30

2.1.2 As grandes categorias do corpus de ARN ........................................................ 31

2.1.3 Da riqueza à pobreza, da pobreza à riqueza .......................................................32

2.1.4 O mercantilismo disfórico ................................................................................ 36

2.2 Da metalinguagem da Semiótica à metalinguagem da Economia ..................... 40

2.3 Entre o profundo e o narrativo: no limiar da conversão dos níveis..................... 42

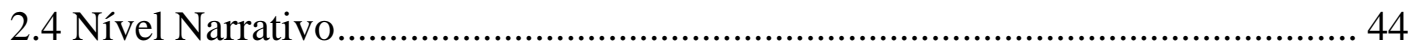

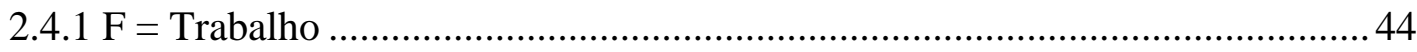

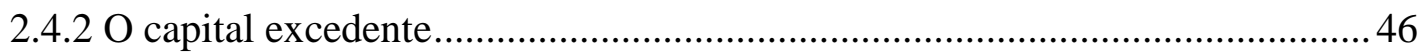

2.4.3 Salário, Lucro e Renda: objetos capitais .........................................................4

2.4.4 A(s) performance(s) do sujeito sincrético "senhor da terra" .............................49

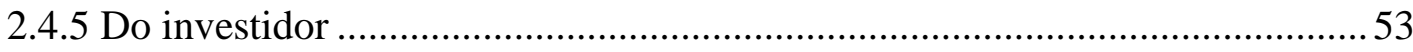

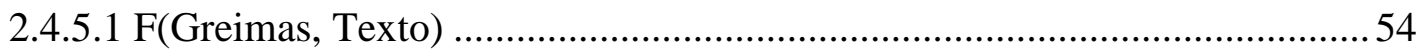

2.4.5.2 A sanção pragmática: salário ……………………………………………....57

2.4.6 O investidor, o senhor da terra e os objetos de valor........................................59

2.4.7 A função do trabalhador entre nação e bens........................................................61

2.4.7.1 A Divisão do Trabalho e o Poder-Fazer do Actante Coletivo: o trabalho

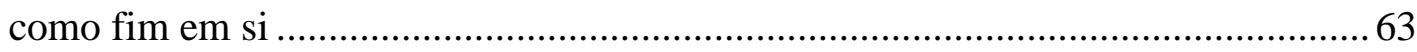

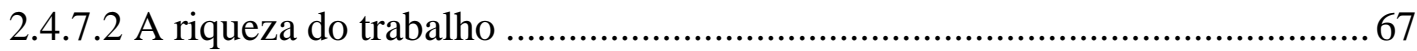

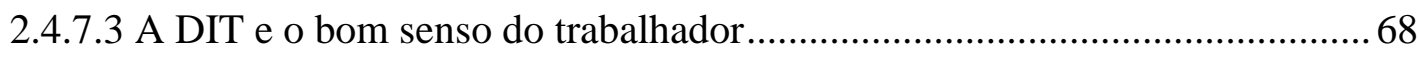

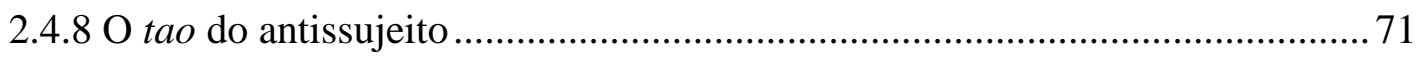

2.5.6.1 A mão invisível e o senso comum.................................................................. 83

2.5.6.2 A individualidade e a mão invisível em ARN ……………………………....... 84

2.5.6.3 Do interesse, da liberdade e do mercado ....................................................... 87 


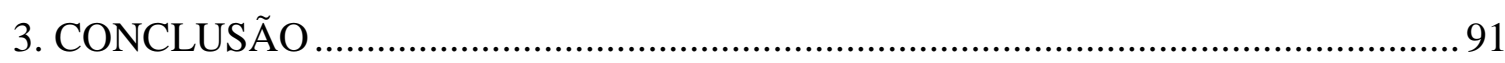

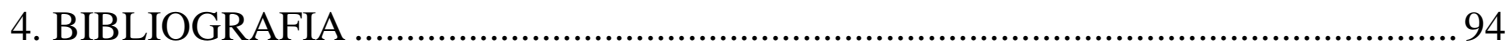




\section{INTRODUÇÃO}

Há muito a análise semiótica greimasiana tem se mostrado eficaz tanto na abordagem de textos verbais, quanto naqueles que possuem maior complexidade do plano de expressão, como os gestuais e os ditos sincréticos. A pluralidade de objetos de pesquisa se equipara à diversidade de gêneros que os compreendem: filme, música, literatura, histórias em quadrinhos, videogame, poesia, dentre outros. Hjelmslev ([1943] 2006, p.19) tempos antes preconizou a respeito dos encaminhamentos sobre essa abrangência das teorias da linguagem:

Uma teoria deve ser geral, no sentido em que ela deve pôr à nossa disposição um instrumental que nos permita reconhecer não apenas um dado objeto ou objetos já submetidos a nossa experiência como também todos os objetos possíveis da mesma natureza suposta.

A pesquisa em semiótica progride cada vez mais para dar conta desses novos gêneros que "extrapolam o texto" narrativo tradicional, sobretudo no tocante aos novos objetos da esfera cultural, científica e das interações sociais (PORTELA, 2008, p. 101, grifo nosso). Seguindo pela esteira de tais evoluções, chegando até Greimas, e passando pela sociossemiótica de Landowski, a semiótica desagua nas atuais propostas tanto da tensividade de Zilberberg quanto das teorias acerca dos modos de existência, as formas de vida e os níveis de pertinência de Fontanille:

[se por um lado] o programa de pesquisa da semiótica greimasiana focou o nível de pertinência do texto e dos enunciados que o compõem, por outro, a semiótica foi considerando, pouco a pouco, a existência de outros níveis de pertinência semiótica e isso desde muito cedo, se considerarmos sua evolução histórica. [...] Os anos de 1990 testemunharam o surgimento de análises de objetos e práticas cotidianas, como as análises de Floch (1990) sobre os viajantes do metrô parisiense ou sobre a identidade visual e o conceito das campanhas publicitárias, ou, ainda, suas análises sobre a faca francesa da marca Opinel ou o look de Coco Chanel (Floch, 1995). (PORTELA, 2008, p. 98)

Por conta de tais avanços na elaboração da teoria e da sua eficiência analítica para lidar com objetos de toda ordem, parece coerente e legítima a aplicação de seu método de análise sobre obras basilares das teorias econômicas, como as liberalistas e as socialistas, uma vez que têm vital importância para a reflexão dos comportamentos das massas, dos 
processos e eventos que afetam a geração de recursos fundamentais para a manutenção e a sobrevivência dos povos, lidando com a relação entre pessoas e meio através de um viés socioeconômico complexo.

Ademais, é importante salientar a existência de uma literatura acadêmica de áreas alheias às da própria Economia e Sociologia (Política), as quais colocam as práticas e as teorias econômicas sob o exame de outros prismas analíticos, tais como da semiótica de Charles Sanders Peirce, da Análise do Discurso, por exemplo, servindo de ferramental para a reinterpretação desse jogo de significações existentes.

Dentre esses, há trabalhos como o artigo “Análise Semiótica Crítica e Economia Política Crítica Cultural”, do professor Bob Jessop (2010), do departamento de Sociologia da Universidade de Lancaster, Reino Unido, em que se discute a semiose nas práticas econômicas funcionais e na sua materialidade existente na trama da sociedade civil; já na tese Conflitos de Competência na Tributação do Consumo, do então doutorando José Alberto Oliveira Macedo (2013), da Faculdade de Direito da Universidade de São Paulo, verifica-se capítulos como o 1.4 "Signo e Conceito - Enunciado e Proposição", no qual o conceito sígnico de "serviço" é examinado na prática tributária de impostos, e a configuração que esta prática adquiriu na interpretação do direito econômico e na jurisprudência atuais, tudo através do arcabouço conceitual de uma interpretação metalinguística própria da filosofia do direito.

Embora tenha que se ratificar nesta introdução uma cautela ao denunciar um provável ambiente de pouca fertilidade em relação aos trabalhos de análise da escola semiótica greimasiana sobre as teorias econômicas, ainda assim - e por isso mesmo - tal objeto parece bastante convidativo e mostra-se bastante aberto para esse tipo de pesquisa, reiterando-se, então, a importância e a urgência da intervenção investigativa da semiótica de Greimas sobre a área da Economia e suas teorias, tão caras às humanidades.

Eis o ensejo no qual a dissertação agarra-se e estabelece para si mesma, como horizonte de seu percurso gerativo de sentido, a pesquisa de uma obra fundamental daquele que é considerado o pai da economia moderna e das teorias liberais do século XVIII, Adam Smith e sua basilar Investigação Sobre a Natureza e as Causas da Riqueza das Nações.u

Para além do caráter crítico ao regime de governo monárquico de sua época e das consequências nada positivas do então mercantilismo em vigência, a obra secular de Adam Smith, escrita em 1776 e dividida em cinco livros, apresenta no volume inicial e no 
decorrer dos demais algumas das proposições fundamentais de seu já demonstrado pensamento filosófico na Teoria dos Sentimentos Morais, de 1759.

Destarte, ideias como o "interesse" público e comum no enriquecimento, o respeito às "individualidades" e estas às leis, e a "Divisão do Trabalho" (DIT) são fundantes na sua teoria, consideradas como as forças propulsoras e inerentes a todos aqueles que desejam conquistar algo para si, e apresentadas em A Riqueza das Nações (doravante ARN) como instrumentos e práticas características da chamada sociedade de mercado.

Já com esses poucos sintagmas expressos, torna-se possível estabelecer um pequeno recorte de uma micro narrativa smithiana, propondo-se a assunção de sujeitos e de suas modalizações virtualizadas por objetos tais, caracterizado aí o convite para um trabalho de análise semiótica de cunho greimasiano.

$\mathrm{Na}$ esteira desta tentativa saussureana" para se chegar a "respostas" criadas pelo ponto de vista do próprio analista, foi selecionado como corpus de análise todo o livro primeiro, "As causas do aprimoramento das forças produtivas do trabalho e a ordem segundo a qual sua produção é naturalmente distribuída entre as diversas categorias do povo", e o capítulo II, "Restrições à importação de mercadorias estrangeiras que podem ser produzidas no próprio país" do livro quarto, "Sistemas de economia política".

A predileção para a seleção de tal recorte deu-se por conta não só da considerada extensão do livro primeiro com suas 280 páginas, o maior dentre os cinco que compõem a obra, mas principalmente por conta do conteúdo que inaugura os fundamentos, a conceptualização e a apresentação de ideias chaves como o conceito de riqueza, os sucessos e os insucessos de um país em relação a outros, as estruturas e o funcionamento da Divisão do Trabalho (DIT), a origem do dinheiro e seu papel social, ou seja, toda a sorte de termos, conceitos e discursos prontos para serem depurados na oficina do semioticista, traduzindo essas "forças" de sentido impulsionadas nos papéis sociais da cadeia econômica de Adam Smith, sintagmatizados em seus fazeres subjetais, inscritos em um percurso de sentido mais profundo e alocados em tempo, espaço e cadeias isotópicas nos limites entre o conteúdo discursivo e a própria manifestação do texto em si.

Já a predileção pelo capítulo II, do livro quarto, dá-se pelo fato de que, pela primeira e única vez, o termo "mão invisível" aparece tacitamente na referida parte da obra, tão cara ao debate sobre as teorias críticas econômicas, já discutidas por Marx e por economistas e

\footnotetext{
${ }^{1}$ Saussure ([1916] 2006, p. 15), na abertura de seu Curso de Linguística Geral, diz: o ponto de vista é que cria o objeto.
} 
acadêmicos atuais. A nova pergunta que se impõe então é: como um termo tão conhecido e por vezes superestimado e indevidamente interpretado ${ }^{2}-$ e de ocorrência tão singular, tomou tal proporção sobre o pensamento de Adam Smith a partir do recorte em ARN?

Fruto dessa manipulação bem sucedida de pequenas, porém delicadas questões e objetos, eis um trabalho que procura investigar primordialmente os três grandes sujeitos da opus magnum de Adam Smith, submetidos às regras do "jogo do mercado" e, mais ainda, àquela aparente mão indissociável da vontade do sujeito. Como eles agem e por quais objetos agem na sintaxe, no discurso e no decurso de seus atos.

De maneira sucinta e introdutória, são eles: (i) o senhor de terras, dono do lócus amoenus do qual todo investidor necessita em primeira instância, a matéria-prima bruta, tanto para quem inicia sua empresa (tratado em relação ao senhor de terras como arrendatário), quanto para a própria nação, da extração da matéria-prima mais bruta, do alimento obtido com o pastoreio do gado, passando pelas culturas de sementes, verduras e frutas, ao mais complexo, como a pesca e a caça; (ii) o investidor, sendo este o sujeito que despende um alto valor de suas economias privadas para o estabelecimento de seu negócio, termo pressuposto; e (iii) o trabalhador, termo pressuponente de tal categoria - afinal, só há trabalho porque alguém o executa - obviamente sendo o sujeito fundamental sine qua non de toda a trama econômica, sobretudo naquela em que os meios de produção se encontram em estágios mais avançados pós-revolução industrial.

A partir das relações existentes entre esses três sujeitos é que será produzida a mais poderosa commoditie de toda nação, e que se vale de um expediente localizado na superfície do texto da obra como o uso das tecnologias, da pesquisa e do mercado: a força e a por vezes exploração - do trabalho, posta como intencionalidade narrativa responsável pela própria existência semiótica operada nas profundezas do discurso smithiano.

Além disso, a dissertação procura demonstrar de maneira breve e humilde como essa individualidade, consubstanciada na misteriosa força que move os sujeitos em direção aos objetos particulares, aparece semiotizada na ideia liberal frente ao espectro de significação tratado nos níveis mais superficiais do conteúdo (leia-se, nível discursivo) em

\footnotetext{
${ }^{2}$ Santos \& Bianchi (2007) aludem na introdução de seu artigo sobre uma espécie de atenção hiperbólica ao conceito da mão invisível, dizendo "A mão invisível, expressão difundida a partir da obra de Adam Smith, certamente ocupa posição de destaque na história do pensamento econômico. Trata-se de uma metáfora consagrada na economia, ao mesmo tempo que se afigura fonte de interminável polêmica e controvérsia. Deste modo, parece valer a pena realizar um exame mais detido desta noção, segundo proposta que esclareceremos prontamente".
} 
volta do mercantilismo antissubjetal da obra, alvo este de intensa crítica do enunciador de ARN.

\subsection{Uma breve introdução à Semiótica}

Diante do exposto no introito, a semiótica de hoje parece ter evoluído de tal maneira de modo a dar conta da análise de objetos multifacetados devido à "evolução" promovida pelas várias pesquisas e suas maneiras desenvolvidas para lidar com os vários textos sincréticos e mais sofisticados.

Embora a área tenha dado, no últimos tempos, mais atenção a projetos e teorias mais recentes como a sociossemiótica, a semiótica tensiva, a biossemiótica, a etnossemiótica, ainda assim a presente análise opta por aquela semiótica de sempre, originada e elaborada por Algirdas Julien Greimas, o qual se ocupou dos escritos da teoria em sua obra inaugural Semântica Estrutural, publicada em 1966, seguida por mais produções, adaptações e reescritas realizadas durante sua vida.

A análise semiótica greimasiana busca ser ainda uma poderosa teoria das ciências do sentido pari passu com as de grandes predecessores como Charles Sanders Peirce, Ludwig Wittgenstein e até mesmo do próprio Ferdinand de Saussure ${ }^{3}$, por justamente ter em seu núcleo uma proposta científica de análise constituída de uma metalinguagem e método próprio, com seus termos, conceitos e normas.

O pai da semiótica francesa encarregou-se de uma gênese teórica criada a partir dos fundamentos das várias heranças (ZILBERBERG, 2006, p.91-115) recebidas de expoentes das teorias linguísticas estruturalistas e filosóficas, dentre eles, Saussure, Propp e Hjelmslev.

Em seu póstumo e inaugural Curso de Linguística Geral, Ferdinand de Saussure conceitua uma nova abordagem linguística a partir do signo, além de uma nova maneira de se "fazer pesquisa com a língua", tratando-a por seu caráter imanente e não mais subordinada aos desmandos e à redutora instrumentalidade de seu verdadeiro teor, devido tratamento que merecia no projeto: não mais seria meio para se chegar à realidade, senão o

\footnotetext{
3 Ainda que este tenha em seu arcabouço a linguística moderna, o linguista genebrino fala de uma proposta semiológica em seu Curso de Linguística Geral.
} 
fim em si, sem que para isso se elucubre uma suprarrealidade linguística descolada do "mundo real"".

Sausure também visou o sistema subjacente às línguas naturais e sua efetividade prática, separando assim langue e parole. O mestre genebrino vaticinou ainda e alertou para o desenvolvimento da semiologia como ciência abrangente de toda aquela linguística que estava em construção:

A Linguística não é senão uma parte dessa ciência geral [...] Como tal ciência [a semiologia] não existe ainda [...] as leis que a semiologia descobrir serão aplicáveis à linguística [...] (SAUSSURE, [1916] 2006, p. 25)

Já se previa então um estudo que não se limitasse apenas à investigação do signo saussureano, devendo ir mais além, aos signos "mais complexos" da língua: os textos e seus discursos.

De Vladimir Propp advém a proposta de uma taxonomia dos papéis fundamentais operantes no esqueleto narrativo que, no caso, tratavam-se das fábulas e contos de fada eslavos. O formalista russo demonstrou em seu Morfologia do Conto Maravilhoso (1928) uma eficiente e terminologia de estágios narrativos a fim de dar conta de um gênero tão vasto, composto por miríades de figuras em sua superfície. Nascia então uma metalinguagem econômica e que auxiliaria a semiótica nesta morfologia narrativo-sintáxica imbricada nos múltiplos discursos.

Por último, e não menos importante, Louis Hjelmslev aparece no cenário estruturalista como pilar para a respectiva teoria, quando da publicação de seu Prolegômenos a uma Teoria da Linguagem (1943). Em primeira instância, o linguista dinamarquês propõe uma visada para toda e qualquer teoria da área das humanidades que queira estabelecer uma epistemologia de caráter científico.

Para isso, Hjelmslev ([1943] 2006, p. 11) concebe os princípios de uma teoria descritiva que "deva ser não contraditória, exaustiva e tão simples quanto possível”, além de redesenhar a concepção combinatória do signo linguístico proposta por Saussure, considerando significado e significante como os dois planos de expressão, havendo, na

\footnotetext{
4 Paula Martins de Sousa (2016, p. 14) apresenta uma sucinta e efetiva explicação sobre a imanência da língua, de modo a rebater as constantes críticas que, por vezes injustamente, as teorias estruturalistas e imanentistas sofrem: "Mas a perlaboração colaborativa entre realidade e linguagem não pode deixar de contar com as restrições impostas pela materialidade: o fato de haver um espectro contínuo no arco-íris e de cada língua discretizar as cores a seu modo não faz com que a cor que, em nossa língua, chamamos de preto, possa ser encontrada no arco-íris por outra comunidade que se valha de uma outra língua qualquer.”
} 
verdade, um tratamento que reúne uma substância do conteúdo e da expressão e uma forma do conteúdo e da expressão. Desses postulados metodológicos e conceituais, Greimas se vale e leva às últimas consequências, como o princípio dedutivo e econômico de sua teoria, basilar para a elaboração de um número reduzido de categorias que dê conta da amplitude e da variabilidade dos objetos textuais, aplicadas sobre a forma do conteúdo e a forma da expressão postos em processo, no sentido hjelmsleviano.

Assim sendo, ainda que progenitora e matricial, a semiótica greimasiana e seu caráter pioneiro em nada desabonam sua aplicabilidade e eficiência frente às demais teorias mais atuais. Greimas mantém seu caráter de mestre introdutor de uma poderosa ferramenta de compreensão profunda e assertiva dos textos, e por ele mesmo reconhecida como ciência em construção, prescrita desde seu nascedouro com o caráter 3.0 da teoria, gesto inegável de humildade e seriedade de sua ciência.

\subsubsection{O percurso gerativo greimasiano de sentido e sua contribuição para o "ser" da análise: nível narrativo, fundamental e discursivo.}

Uma vez que o presente trabalho se divide em três tipos de análise sobre o mesmo objeto, faz-se de bom modo apresentar um breve panorama sobre cada um desses níveis antes de se aprofundar em cada capítulo.

Sendo assim, Greimas desenhou sua teoria tendo como ponto norte o percurso gerador de sentido através de suas estruturas subjacentes à cobertura do texto, localizadas no plano do conteúdo hjelmsleviano, ou seja, essa trajetória do sentido se dá ascendentemente do nível mais elementar, categorizado e universal ao mais complexo e saturado de termos, chegando ao mais próximo de sua cobertura textual. Obviamente, sem deixar de desconsiderar o percurso descendente no qual se trata do aprofundamento do olhar da análise.

São elas três, respectivamente, em ordem do mais abstrato e profundo ao mais concreto e superficial: o nível fundamental, narrativo e discursivo. 


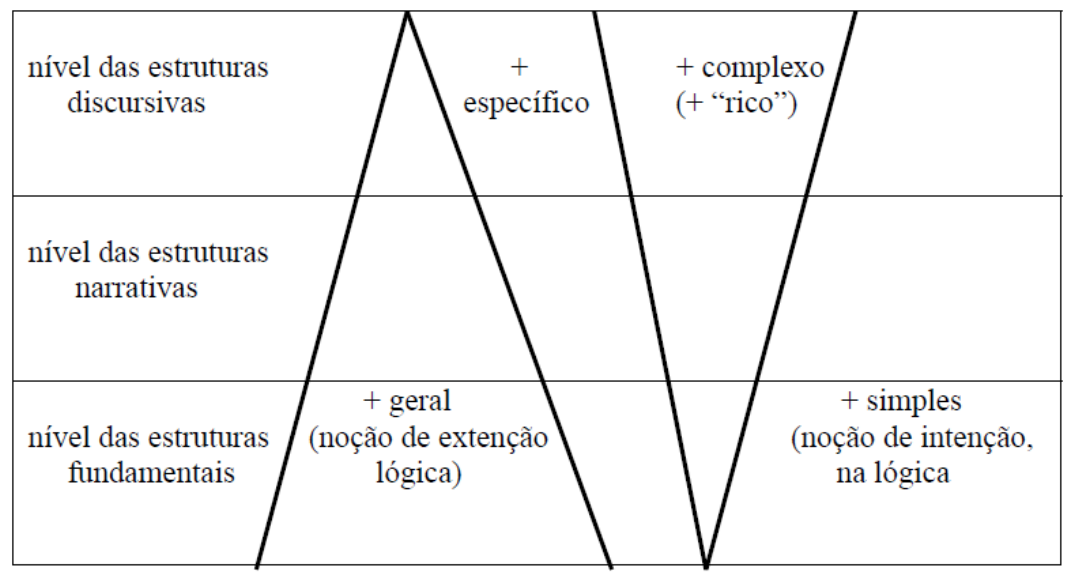

(Barros, 2002, p. 115)

No nível fundamental, estão os valores semânticos mínimos em nível de processo de significação, partindo de uma oposição lógico-semântica entre duas categorias contrárias, reunidas sob um mesmo termo valor, representativo de todo o valor que será investido no objeto. Por conseguinte, o quadrado semiótico expõe sintaticamente essa relação entre cada uma daquelas categorias, através das etapas de negação, denegação e afirmação.

Através desse quadrado são estabelecidos os termos que, em relação contrária, produzem a significação do texto como um todo, tal qual a mesma lógica do pensamento do signo saussureano, em que um signo só produz sentido por conta de sua diferença em relação a outro signo.

Cada um desses termos contraem entre si uma função chamada de contrariedade (S1 e S2), tendo respectivamente cada uma delas suas complementaridades ( $\tilde{\mathrm{n}} 2+\mathrm{S} 1$ e $\mathrm{S} 2+\tilde{\mathrm{n}} \mathrm{S} 1)$ e seu eixo da contradição ( $\tilde{n} S 1+S 1$ e $S 2+\tilde{n} S 2)$.

Ligado a esse processo que se dá no nível mais abismal do texto está o caro primado da existência semiótica ${ }^{5}$, anterior a todo e qualquer tipo de manifestação textual, a qual Greimas tratou como uma espécie de porto seguro da teoria com fins de se manter em terra firme do princípio da imanência do texto e da não ontologização do sujeito.

Como se notará no próprio capítulo de análise, tal nível se mostra extremamente eficaz para a demonstração do macrossentido da obra, lugar esse onde se depositam as

\footnotetext{
${ }^{5}$ Em Semiótica e Ciências Sociais, Greimas diz, "longe de apreender de maneira imediata uma das grandezas de que se supõe ser constituída a manifestação, nada mais fazemos que emitir um julgamento de existência sobre essa grandeza: produzimos assim um primeiro enunciado a propósito da manifestação, cujas grandezas não passam de pretextos a partir dos quais objetos linguísticos serão construídos por meio de determinações sucessivas". ([1975] 1981, p.12).
} 
oposições mais básicas de ARN, como por exemplo, o liberalismo versus o mercantilismo, tão caro ao próprio discurso de Adam Smith.

Da passagem de um nível ao outro, o nível fundamental é articulado então numa espécie de narratividade profunda do texto, "concretizando" os valores mais abstratos numa sintaxe entre actantes que operam as transformações dentro desse percurso, só que especificamente em direção a um objeto. Nas palavras de Barros (2002, p. 27), “entende-se a sintaxe narrativa como o simulacro do fazer do homem que transforma o mundo".

É o lugar de análise onde o percurso gerativo de sentido recebe o investimento de um sujeito em relação a um objeto de valor, colocando em movimento sintático e revestimento semântico as categorias que pareciam desprovidas de uma interferência humana na pŕatica narrativa do texto (com seus enunciados de fazer e de ser) e na parte mais superficial do texto (no corpo que cria sentido pelo texto, através da enunciação). Nesse nível de análise, todos os fazeres e estados de certo número de sujeitos se combinam em enunciados mais ou menos complexos para justamente impulsionar o sentido mais abstrato contido na profundidade do nível fundamental.

É através desse nível que a semiótica consegue apresentar uma hipótese sobre quem seria, ou quais seriam, por exemplo, os adjuvantes e os protagonistas da narrativa smithiana, seus objetos de valor, e como fazem para chegar até esse objeto, e sob qual influência modalizadora estariam submetidos.

Finalmente, o último nível de análise demonstra as estratégias e o ponto de vista do enunciador de uma enunciação pressuposta ao texto, pois "sendo o texto uma manifestação, e o discurso, conteúdo" (LOPES; HERNANDES, 2005, p. 170), a esse estrato se dá o nome de nível discursivo, dirigido por um enunciador que escolhe o que vai ser dito e como será dito.

Sobre essa escolha arbitrária do enunciador, dois aspectos merecem ser elencados: as projeções da instância da enunciação no enunciado e as relações entre enunciador e enunciatário, ou seja, a argumentação (FIORIN, 2009, p. 57).

O conceito de embreagem e debreagem, sendo uma em direção à enunciação e a outra se distanciando dela, na devida ordem, pode demonstrar na análise os efeitos de sentido que o enunciador da obra escolhe para, da melhor maneira possível, manipular seu enunciatário.

Seja ela dando voz a outros actantes discursivos, de modo a objetivar seu discurso, ou a si próprio, de maneira a marcar sua proximidade e autoridade por se ancorar ao espaço 
e ao tempo de seu objeto, tais estratégias serão discutidas no referido capítulo do nível discursivo.

Por último, mas não menos importante, as isotopias textuais marcarão na obra os revestimentos figurativos (mais concretos) e temáticos (mais abstratos) do discurso, sendo o lugar de exposição da vastidão de temas que podem aparecer nos discursos impostos ao leitor. Ao ser analisada a ARN, foi possível propor uma recorrência de temas caros à ideologia liberal tal qual esta se apresenta em alguns manuais e meios de estudo.

Parece legítimo, por fim, assumir que a abordagem semiótica consegue dar uma luz elucidadora para aquilo que acontece no estabelecimento das ideologias liberais clássicas em um sentido mais restrito, e mesmo das formas semióticas pertinentes ao discurso econômico, provando ser este, também, uma espécie de produto das trocas de sentido e valores linguísticos, tanto mais que dos valores mercadológicos.

\subsection{Uma breve introdução à economia}

Desde os primeiros estudos na fase escolar sobre o curso da História do mundo e os processos (des)envolvidos na camada que subjaz seus mais variados episódios, é possível perceber uma trama predominante em todas estas extensões narrativas: a economia e suas relações no cerne dos acontecimentos.

Segundo a perspectiva das próprias ciências econômicas, seja nas violentas invasões expansionistas do XVI, no descontentamento de um grupo de comerciantes na Boston colonial do XVIII ou numa das mais importantes - senão a mais - revoluções do mundo, a Revolução Francesa, são as práticas econômicas as responsáveis por erigir e sustentar os desdobramentos narrativos mais variados no trajeto da humanidade.

Conforme propõe o analista econômico Edmund Conway ${ }^{6}$ (2015), a Economia é o estudo dos tipos de mercado e da circulação de dinheiro na sociedade, ou seja, uma investigação sobre como as diversas nações têm sucesso e fracasso na geração de bens. Ainda segundo o mesmo autor, a Economia é o estudo sobre "como a humanidade conseguiu, ao longo de gerações, tornar-se mais saudável e próspera do que antes". (CONWAY, [2009] 2015, p. 07).

\footnotetext{
6 Edmund Conway é pós-graduado pela Universidade de Harvard, ex-editor dos jornais britânicos de economia Daily Telegraph e atualmente é editor do periódico Sky-News.
} 
Sobre esta tal prosperidade e sucesso, entendem-se os modos de exploração, os meios de produção e as formas de administração de recursos por seus diversos atores em um dado cenário, do escambo de espelhos foscos entre colonizadores e colonizados, ao pacote de medidas orçamentárias na China dos dias atuais.

Ainda que tais estudos apresentem equações e fórmulas matemáticas para se auferir dados sobre a situação de um povo, as ciências econômicas se encarregam, sobretudo, de discursivizar as causas e os efeitos de práticas legítimas ou controversas como, por exemplo, uma taxação alfandegária mais restritiva.

Trata-se dos estudos dos fatores que interferem na distribuição de renda, na oferta e procura e nos preços das mercadorias. Sua preocupação fundamental refere-se aos aspectos mensuráveis da atividade produtiva, recorrendo para isso aos conhecimentos matemáticos, estatísticos e econométricos ${ }^{7}$.

Por esse viés mais geral já é possível vislumbrar um percurso gerativo e alguns papéis actanciais - um deles devidamente preenchido pelo ator "humanidade" - o qual tem a intenção de entrar em conjunção com seu objeto, alcançando um suposto estado fórico de prosperidade e plenitude.

Ao comparar algumas linhas teórico-econômicas de bases ideológicas diferentes, verifica-se que a relação entre os agentes (actantes) difere de várias maneiras para a consolidação de uma economia saudável.

No socialismo "científico" 8 de Karl Marx, por exemplo, o autor alça o Estado como agente essencial numa posição hiper-hierárquica para a manutenção de uma sociedade ${ }^{9}$ coesa e comprometida com o bem comum, com o objetivo de alcançar a autonomia dos povos pelo comunismo ${ }^{10}$.

Em contrapartida, numa observação mais superficial da obra A Riqueza das Nações (1776), parece haver uma sintaxe narrativa diversa da de Karl Marx, construída com outros

\footnotetext{
${ }^{7}$ SANDRONI, 1999.

${ }^{8}$ Termo utilizado pelos próprios Marx e Engels com o propósito de se diferenciarem do socialismo utópico de Owen, Saint-Simon e Fourier (apud SANDRONI, 1999, p. 567).

9 "Em uma sociedade comunista, a propriedade e os meios de produção (fábricas, ferramentas, matériasprimas, etc.) não pertenceriam a indivíduos ou empresas, mas a todos. Inicialmente o Estado possuiria e controlaria empresas e instituições, gerindo-as de cima para baixo, assegurando que as empresas não oprimiriam seus trabalhadores. Com o tempo, porém, o Estado iria desaparecer." (CONWAY, [2009] 2015, p.50).

${ }^{10}$ Doutrina que defende a abolição da propriedade privada dos meios de produção, a distribuição igualitária dos bens produzidos pela sociedade e que a organização da riqueza social seja feita pela própria comunidade de produtores. Propõe ainda a extinção do Estado, o autogoverno da coletividade e o fim das classes sociais. (Sandroni, 1999, p. 116).
} 
tipos de enunciados de fazer e de estado entre destinador e destinatário/sujeito, impelindo este último em direção a um objeto de cunho mais individual, ao passo que o primeiro nada mais é que um papel actancial prévio, de um sujeito em potência, a ser competencializado e manipulado:

[o indivíduo] não tem a intenção de promover o interesse público, nem sabe o quanto o promove [...] ao dirigir sua atividade de maneira a valorizar ao máximo a produção, visa apenas seu próprio lucro, e nisto, como em muitos outros casos, é guiado por uma mão invisível a promover um fim que não fazia parte de sua intenção. (SMITH, [1776] 1996, p. 438).

Embora ambas as obras tenham ideologias diferentes, destinatário e sujeito são igualmente revestidos por atores figurativizados antropomorficamente trabalhadores/indivíduo/sociedade. A divergência fica por conta dos destinadores inscritos em cada uma delas e pelas suas ações (fazeres) operados nas etapas que lhes competem, o que parece justificar uma análise semiótica para identificar destinador e destinatário/sujeito com fins de se aprofundar sua relação e demonstrar, através de uma metalinguagem semiótica, as estruturas e os efeitos de sentido que se produzem desta relação.

Eis que a economia parece situar-se em duas posições discursivas diferentes: a Economia pura, a qual realiza uma análise descritiva dos sistemas econômicos vigentes e passados em uma sociedade, auferindo coisas como a orientação deste ou daquele sistema econômico, se de mercado ou planificado de estado, e a Economia aplicada, que tem sua função prescritiva das ações com fins de se obterem resultados futuros, formulando hipóteses e recomendações para a regência de um país.

Enquanto a chamada "economia pura" cuida da formulação conceitual abstrata da realidade econômica, a economia aplicada tem a função normativa de determinar alternativas, métodos e processos de produção tanto no âmbito da empresa quanto no da sociedade. (SANDRONI, 1999, p. 189)

Seja destinadora-julgadora, seja destinadora-manipuladora, a economia se autodenomina e se estabelece epistemologicamente ora segundo suas práticas, ora segundo seus fazeres, e, por conta dessa característica, parece complexo e por vezes paradoxal o seu papel, visto não serem raros os debates e questionamentos acerca de medidas e 
encaminhamentos adotados por líderes, políticos, ministros, e todos aqueles responsáveis pelas estratégias da administração financeira de um país.

Ainda que com as diferentes abordagens concernentes aos propósitos das ciências econômicas, vieses e crenças, a Economia sempre terá como horizonte a evolução e o desenvolvimento da espécie humana, todas focadas no bem estar geral, por mais que se questione a clássica definição de evolução e "desenvolvimento", sob a clássica dicotomia econômica "crescimento x desenvolvimento", ou mais especificamente, a ideia de produção de soluções teóricas e prático-tecnológicas $v s$. a noção de progresso ${ }^{11}$.

\subsubsection{Uma breve introdução a Adam Smith e sua investigação sobre a natureza e as causas de A Riqueza Das Nações}

Nascido no ano de 1723 em Fifeshire, na Escócia, Adam Smith fora filho único de um funcionário público e de uma descendente de donos de grandes terras. Sobre sua escolarização, já na adolescência tivera contatos com os estudos de Humanidades, que compreendia estudos clássicos, Teologia e Filosofia.

Mais precisamente, o então Professor de filosofia Moral, Francis Hutcheson, famoso por suas contribuições teóricas nos estudos do Direito Natural, é quem desde cedo destinou o então jovem destinatário no pensamento crítico e reflexivo. Smith, entretanto, abandona a racionalidade do método jusnaturalista para dar preferência a uma metodologia essencialmente empírica, e que não podia se valer apenas de um raciocínio abstrato dedutivo, mas de um pensamento baseado em sistemas e princípios gerais derivados de algum tipo de observação. Vislumbram-se já os primeiros traços de um pensador que se distancia das tradições do pensamento filosófico e vai em direção ao cientista observador da vida social orgânica.

Ainda assim, antes da produção de sua magnum opus, Smith traria a público sua The Theory of Moral Sentiments [Teoria dos Sentimentos Morais], publicada em 1759, título este que trazia uma série de capítulos com reflexões sobre diversas áreas do conhecimento, dentre elas, economia e política.

\footnotetext{
${ }^{11} \mathrm{O}$ termo em destaque (progresso) é uma breve alusão ao equivalente discutido na obra de Larry Laudan, $O$ progresso e seus problemas, ([1977] 2011) na qual o pesquisador discute a linha tênue que há nas pesquisas científicas atuais, distinguindo progresso científico da racionalidade científica.
} 
Após um longo período de percursos pessoais e profissionais entre a Inglaterra e a França, em que travou contato mais e menos intensos com personalidades como Hume e Voltaire, Smith finalmente inicia em Kircaldy a escrita do seu mais ambicioso projeto, debruçando-se sobre ele por um período de cerca de seis anos.

Finalmente, em 1776, é publicado An Inquiry into Nature and Causes of the Wealth of Nations [A Riqueza das Nações: uma Investigação sobre sua Natureza e suas Causas], entretanto, como toda grande obra, o fôlego e a força necessários para sua disseminação só se dariam quase duas décadas depois ${ }^{12}$.

A obra contou com cinco edições durante a vida de Adam Smith, sendo a última de 1789, a mais reproduzida e traduzida, devido às suas correções realizadas pelo próprio autor.

Além do caráter pioneiro da obra de elevar os estudos de economia a um patamar mais científico/empírico, a Riqueza das Nações parece propor, acima de tudo, três pontos a serem analisados: o ambiente socioeconômico que o cercava naquele momento, um sistema mercantilista e colonialista que perdurava em muitos países na Europa; o fenômeno do crescimento do ponto de vista econômico de alguns países; e postular a chave para o aprimoramento do trabalho e a produção de bens, fundador para as ideias liberais.

Em relação ao crescimento, criou-se um termo que fora identificado como riqueza per capita, "índice" desenhado pelo próprio economista inglês, basicamente, na "relação entre a produtividade do trabalhador, o excedente de sua produtividade e a população total de um país" (SMITH, [1776] 1996, p. 59) ${ }^{13}$.

Sobre o mercantilismo é necessário entender que, naquele momento, tratava-se de um sistema econômico que tinha como cerne a supervalorização de metais preciosos, o que acabava por estimular a exploração colonialista estrangeira, o protecionismo em relação ao comércio exterior, e por consequência configurava poucas trocas comerciais entre países, além do pouco estímulo à agricultura. Em artigo publicado na Revista de Economia em 2007, a professora da Faculdade de Economia e Administração, Laura Valadão Mattos, alude a tal sistema mercantil, como sendo o objeto centralizador da crítica de Adam Smith

\footnotetext{
12 Dados biográficos retirados do capítulo de apresentação da edição brasileira de ARN, assinado por Fritsh, 1996.

13 Faz-se mister distinguir o esquema apresentado na obra smithiana (riqueza per capita) do índice criado pelo Nobel de Economia, Simon Kuznets, PIB, o qual pode ser didaticamente apresentado como uma soma entre consumo + investimento + gasto público + valor líquido de exportações. Entretanto, é importante salientar também que mesmo esta e a supracitada forma de aferição de riqueza de um país são limitadas e ineficazes para a medição, por exemplo, das desigualdades e da qualidade ambiental. (CONWAY, 2015: 77)
} 
em ARN, “É quase impossível caracterizar o que seria o 'sistema de liberdade natural' de Smith sem fazer referência ao que ele denomina 'sistema comercial ou mercantil', uma vez que o primeiro aparece praticamente como uma antítese do segundo". Sendo assim, um dos pontos de partida para entendimento dessa extensa obra é saber que, além de seu caráter pedagógico sobre as práticas de um Estado economicamente liberal, há também seu caráter sancionador sobre o sistema econômico predominante do velho continente.

Uma observação é necessária com relação à sua crítica ao Estado mercantil: em ARN, no livro IV, capítulo IX, o autor jamais aboliu a função do Estado (soberano), muito pelo contrário, a ele se refere como mantenedor caro e indispensável para pastas básicas, como a saúde, a educação e a justiça:

\begin{abstract}
Segundo o sistema da liberdade natural, ao soberano cabem apenas três deveres, por certo, de grande relevância, mas simples e inteligíveis ao entendimento comum: primeiro, o dever de proteger a sociedade contra a violência e a invasão de outros países independentes; segundo, o dever de proteger, na medida do possível, cada membro da sociedade contra a injustiça e a opressão de qualquer outro membro da mesma, ou seja, o dever de implantar uma administração judicial exata; e, terceiro, o dever de criar e manter certas obras e instituições públicas que jamais algum indivíduo ou um pequeno contingente de indivíduos poderão ter interesse em criar e manter, já que o lucro jamais poderia compensar o gasto de um indivíduo ou de um pequeno contingente de indivíduos, embora muitas vezes ele possa até compensar em maior grau o gasto de uma grande sociedade. (SMITH, [1776] 1996, p. 170)
\end{abstract}

A respeito do funcionamento do núcleo duro da teoria formulada por Adam Smith, postula-se uma circularidade cumulativa, em que a divisão do trabalho aumenta a produtividade, que produz um excedente de capital (custo do produto final - lucro = salário) permitindo o estoque de capital. Por sua vez, para que se reproduza mais riqueza, o excedente necessita ser investido novamente na criação de mais postos de emprego, estimulando uma oferta maior que a demanda de trabalho, provocando um crescimento concomitante de salários - e melhora das condições de vida dos trabalhadores, ampliando a qualidade de vida e o tamanho da população disponível para o próprio mercado, o qual, por sua vez, é condição pétrea para o estoque de capital (formação de capital/poupança) ${ }^{14}$.

\footnotetext{
14 A essa trama se dá o nome de "processo de causalidade circular cumulativa", citada por Sandroni em sua apresentação na referida obra, a qual foi criada por Gunnar Myrdal, economista sueco, autor da consagrada obra The Political Element in the Development of Economic Theory, 1953.
} 
Para isso o autor inicia sua obra asseverando, muito simplificadamente, que a riqueza de um país nada mais é que a produção de bens e serviços realizados pelas mãos daqueles que estão na linha de frente da máquina econômica, ou seja, o trabalhador, e que este, por sua vez, só terá sua força de trabalho otimizada sob o regime da Divisão do Trabalho e das máquinas e tecnologias de última geração. Acerca desta última, do trabalho com as máquinas e a produção em larga escala, o autor afirma serem três os grandes setores em ordem de importância para a sociedade: a manufatura, a agricultura e o comércio, em ordem de investimentos e atenção dos próprios governos que visam à prosperidade de seu país.

Por fim, é proeminente a ideia do indivíduo, da especialização dele e da própria sociedade, nos mais variados setores e polos de produção, o que acaba por estimular uma espécie de troca entre pessoas e países, deixando subentendido a noção de que é melhor, por exemplo, que um país, rico em pastagens, topografia e mão de obra adequadas para a produção bovina e ovina, foque nesse tipo de negócio e deixe que demais produtos ou commodities, não autossuficientes em relação a tais condições, sejam produzidos por outros países, ao invés de despender esforço e investimento alto para uma produção irrelevante.

A velha máxima "tempo é dinheiro" e "menos é mais" se ancoram muito bem ao projeto de ARN.

\section{ANÁLISE}

\subsection{Nível Fundamental}

\subsubsection{O quadrado semiótico em A Riqueza das Nações}

Dentre suas inúmeras ferramentas de trabalho, aquela que parece ser a mais representativa e reconhecida na comunidade estruturalista, e que simboliza mormente Greimas, é o quadrado semiótico e seu percurso gerador de sentido.

Em colaboração com François Rastier (GREIMAS, [1970] 1975, p. 127), o mestre lituano descreve a funcionalidade e a importância das estruturas lógicas mais profundas e universais frente à infinidade de textos e suas particulares manifestações. A demonstração desses valores subjacentes ao texto se dá no nível fundamental, através de um percurso sintático e, obviamente - e por isso mesmo - semântico. 
Nesse trajeto da significação do quadrado, onde o significado aparece articulado em um esquema de relação entre contrariedades e negações unidas por um elemento em nível supralinguístico, comprova-se o caro postulado de Saussure sobre o valor do signo, muito bem reapresentado por Edward Lopes como elemento realizável da langue, puramente opositivo (LOPES, 1997, p. 102).

Sob tal ferramental, então, o corpus de texto de Adam Smith é submetido e analisado para que, numa instância mais imanente da língua, observe-se o jogo de valores basilares decantados da massa textual de sua superfície.

O quadrado semiótico demonstrará como as oposições semânticas e os percursos sintáticos são gerados a partir da "riqueza" e da "Divisão do Trabalho" apresentados nas profundezas do discurso smithiano.

\subsubsection{As grandes categorias do corpus de ARN}

A hipótese do texto de Adam Smith, não à toa condizente com o título conferido à obra, apresenta em suma a capacidade de uma nação em gerar riqueza por e para seu povo. Logo na abertura, o enunciador critica as nações pouco organizadas e evoluídas nas suas formas de produção, ou, nas palavras do próprio enunciador, nações selvagens:

Entre as nações selvagens, de caçadores e pescadores, cada indivíduo capacitado para o trabalho ocupa-se mais ou menos com um trabalho útil [...] Todavia, tais nações sofrem tanta pobreza e miséria que, somente por falta de bens, frequentemente são reduzidas [...] (SMITH, [1776] 1996, p.59)

Mesmo aqueles povos que tinham acesso ao mais vasto campo de jazidas de pedras e metais, como os peruanos, nas palavras do autor, ainda assim não produziam riqueza e desenvolvimento suficientes, justamente por conta de seus modos de obtenção de bens através do escambo e da escravidão ${ }^{15}$.

A partir desses e de outros variados excertos ${ }^{16}$ o enunciador apresenta seu diapasão teórico sobre os meios de produção através da Divisão do Trabalho (DIT), o qual fragmenta o processo, multiplicando para isso as tarefas com o intuito de se achegar a um dado objeto.

\footnotetext{
15 SMITH, [1779] 1996, p. 234.

${ }^{16}$ p. 117 e os salários naturais; p.71 e os reis da África; p.203, aprimoramento da agricultura.
} 
Essa prática é extremamente necessária para se otimizarem os resultados e gerar uma vasta gama de tipos de trabalho, produtos e, consequentemente, quantidade de bens. Por conseguinte, tais bens devem estar sempre em uma proporção maior do que aqueles que a consomem, a fim de se gerar reserva para o povo:

Conforme, portanto, essa produção, ou o que com ela se compra, estiver numa proporção maior ou menor em relação ao número dos que a consumirão, a nação será mais ou menos bem suprida de todos os bens necessários e os confortos de que tem necessidade. (SMITH, [1776] 1996, p. 59)

Segundo a teoria liberal de Smith, só é possível ter uma saúde econômica estável à medida que haja uma espécie de fragmentação de muitos tipos de trabalho ${ }^{17}$, quando não, da segmentação e da especialização de tantos outros.

Sendo assim, a DIT dá as cartas do jogo do capital com as novas formas dos meios de produção de seus trabalhadores, que por sua vez erigem a riqueza de uma nação.

Tem-se, portanto, duas grandes oposições centralizadoras: Riqueza x Pobreza e Concentração x Difusão.

\subsubsection{Da riqueza à pobreza, da pobreza à riqueza}

Antes do tratamento desses dois primeiros valores, é preciso salientar que todo o corpus de trabalho é orientado por uma estrutura elementar opositiva entre aqueles que produzem muito e aqueles que produzem pouco, sendo por diversas vezes tratados, respectivamente, como povos que são ricos e/ou estão em franco progresso e povos que vivem na miséria e/ou estão em declínio.

Obviamente, há uma grande gama de dados que vão da geografia e de uma análise topográfica de diversos lugares do mundo a pareceres com linguagem bastante técnica e de difícil compreensão, como na "Digressão Sobre as Variações da Prata no Decurso dos Quatro Últimos Século" do Livro I, em que a desvalorização da prata fez com que o preço da saca de trigo caísse relativamente na Inglaterra. Esses e todos os outros diversos

\footnotetext{
${ }^{17}$ Salienta-se aqui a não generalização dessa fragmentação, pois o próprio autor, no capítulo X, "Os Salários e o Lucro nos Diversos Empregos da Mão de Obra", propõe cinco circunstâncias sobre a diferença de lucros e salários entre os diversos tipos de negócios e trabalhos, como o caráter agradável/desagradável do emprego; dificuldade/facilidade ao se aprender determinado ofício, etc. Por isso optou-se pelo não ajuizamento de que todo tipo de trabalho está submetido à DIT, mas obviamente, grande parte dele.
} 
apontamentos e proposições sempre são direcionados, no percurso sintático de sentido, para a questão daqueles que têm mais ou menos bens, que são mais ou menos ricos e promissores.

Para um trecho mais preciso, Smith fala, por exemplo, sobre a então colônia dos Estados Unidos como uma região muito mais preparada em sua estrutura econômica do que a própria Inglaterra, a qual estava em progresso, porém muito mais lento:

Embora a América do Norte não seja ainda tão rica como a Inglaterra, é muito mais progressista, avançando com rapidez muito maior para a aquisição de maiores riquezas. [...] O trabalho lá é tão bem remunerado, que uma família numerosa, ao invés de ser um peso, representa uma fonte de riqueza e prosperidade para o país. (SMITH, [1776] 1996, p. 122)

O poder de compra dos vários setores e extratos sociais é, em essência, ter mais recursos para que minimamente se adquiram produtos e serviços fundamentais à sobrevivência e ao bem estar.

Destarte, tem-se de antemão duas grandes oposições articuladas no eixo da contrariedade, /S1 vs. S2/ representados pelos termos /riqueza vs. pobreza/, as quais pressupõem negações e asserções de conteúdos que vão gerar /ñS1 vs. ñS2/, /não-riqueza vs. não-pobreza/:

\section{(EUA) Riqueza $\mathbf{S 1} \quad \mathrm{x} \quad \mathrm{S} 2$ Pobreza (África)}

Os países citados em ARN que se encontravam em situações econômicas complexas, como os Estados Unidos, tornam-se elementos integrantes das categorias profundas dos povos em constante progresso econômico, ao passo que determinadas regiões da África e da Ásia convergem para as categorias de extrema penúria e falta de perspectiva socioeconômica $^{18}$.

A partir dessas quatro grandezas operadas em "primeira geração" ${ }^{19}$, articulam-se as demais relações que expõem este percurso da significação dentro do modelo de análise do quadrado semiótico greimasiano, assumidas como quadrado de segunda e terceira geração:

\footnotetext{
18 "Em contrapartida, todas as regiões do interior da África, e toda a parte da Ásia localizada a uma distância maior ao norte dos mares Euxino e Cáspio - a antiga Cítia, a Tartária e a Sibéria modernas - em todas as épocas, ao que parece, permaneceram no estado de barbárie que ainda hoje as caracteriza." (SMITH, [1776] 1996, p. 80).

${ }^{19}$ BARROS, 2002, p. 22.
} 
a contradição, $S 1$ e ñS1/ S2 e ñS2, e as duas dêixis, $\tilde{n} S 2$ e S1/ ñS1 e S2 constituem as relações da segunda, enquanto que os termos complexos, /S1 vs. S2/, e os termos neutros, /ñS2 vs. ñS1/, são de terceira:

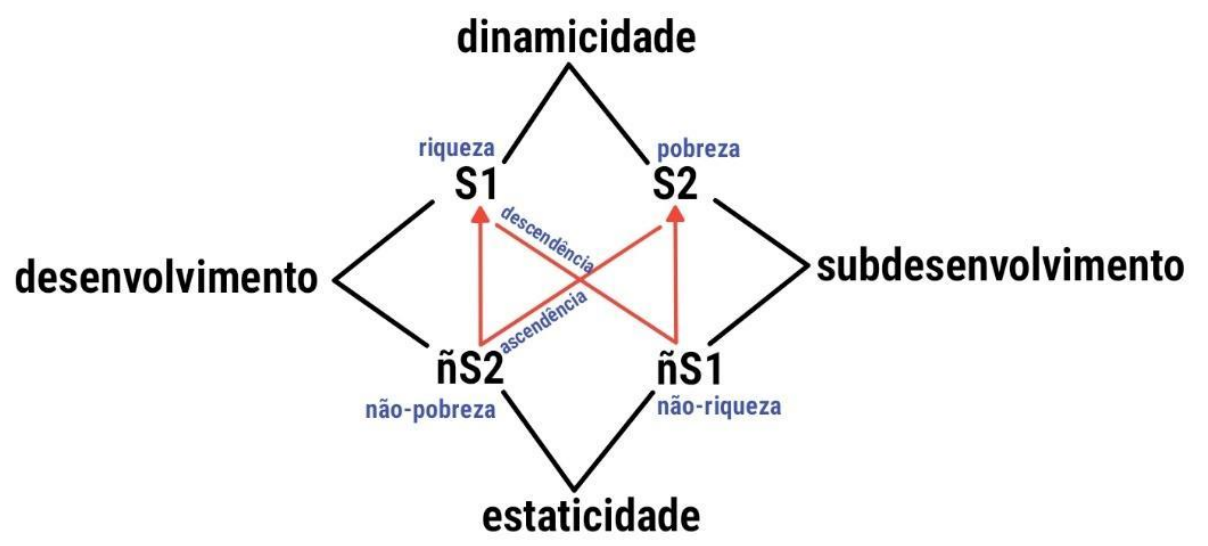

Acerca de tais valores semânticos categoriais encontrados em cada uma das relações acima apresentadas, A Riqueza das Nações chama à baila os estados e os trajetos dos povos na administração dos bens e do trabalho gerador destes, além de uma noção de movimento inscrita por um sujeito mais geral, chamado de "Nação", em que o vai e vem de seu percurso só pode ser executado, por isso mesmo, por sua assunção subjetal diante de um determinado objeto semiótico. Justamente pela instalação de um "corpo" que sente e busca, as axiologias desse ser semiótico se projetam no rastro de seu percurso sintático representado no quadrado.

Greimas assumia o quadrado semiótico como uma espécie de apropriação de um sujeito segundo sua perspectiva, a que chamava de propriocepção, na qual a projeção tímica de sua perspectiva axiologiza as categorias do quadrado semiótico ${ }^{20}$.

Para que se visualize melhor essa ideia, ao se deter sobre os eixos da contradição (S1 e $\tilde{n} S 1 /$ S2 e ñS2), percebe-se que o percurso representa respectivamente uma taxonomia da /descendência/ e da /ascendência/ de um país, portanto, do declínio ou da ascensão de sua situação econômica. Automaticamente se desvelam suas dêixis graças à axiologização dessa infraestrutura do sentido: o caráter fórico do quadrado semiótico, dividido em /euforia/ e /disforia/.

\footnotetext{
20 "Uma categoria semântica pode ser axiologizada pela projeção da categoria tímica no quadrado que a articula, de modo que os termos contrários serão denominados /euforia/ e /disforia/. Trata-se de uma categoria 'primitiva', também chamada proprioceptiva, com a ajuda da qual se procura formular, muito sumariamente, a maneira como todo ser vivo, inserido em um meio, "sente" a si próprio e reage a seu entorno." (GREIMAS, [1983] 2014, p. 104).
} 
De um lado, /S1 e ñS2 / articulam a categoria semântica eufórica assumida como /desenvolvimento/ de alguns países da Europa e até mesmo do próprio exemplo de sua colônia estadunidense. Do outro, /ñS1 e S2/, projeta-se o valor do /subdesenvolvimento/ em que figuram povos e países alvos de intenso regime exploratório e baixíssimo nível tecnológico, como na America do Sul, África e Ásia.

$\mathrm{Na}$ terceira etapa desse degrau das relações dos termos do quadrado, os termos contrários /S1 e S2/ se somam por um grande sema categorial da /dinamicidade econômica/ a qual diz respeito aos caminhos e descaminhos adotados por países em sua busca por uma situação positiva, ou seja, de uma estabilidade econômica provisória e progressiva em relação à junção do objeto, de maneira a estabelecer sua condição, no caso, de posse de bens.

Essa sintaxe profunda das condições socioeconômicas aparece mais claramente ${ }^{21}$ no capítulo VIII (Livro I), "Os Salários do Trabalho", ao conjecturar sobre as condições de vida dos trabalhadores em dado ambiente econômico:

Talvez mereça ser observado que a condição dos trabalhadores pobres parece ser a mais feliz e mais tranquila no estado de progresso, em que a sociedade avança para maior riqueza, e não no estado em que já conseguiu sua plena riqueza. A condição dos trabalhadores é dura na situação estacionária e miserável quando há declínio econômico da nação. O estado de progresso é, na realidade, o estado desejável e favorável para todas as classes sociais, ao passo que a situação estacionária é a inércia, e o estado de declínio é a melancolia. (SMITH, [1776] 1996, p.131)

Advém então o termo neutro /estaticidade econômica/, construído a partir de /ñS2 vs. ñS1/, o qual se refere à estagnação aludida no excerto acima e, logicamente, em outros momentos notáveis do corpus da obra. Sobre essa situação de inércia, caracterizam-se

\footnotetext{
${ }^{21}$ A fim de não se cometer o pecado do excesso de trechos em espaço útil dedicado à análise, optou-se pela discrição das notas para a exposição da lógica profunda da estagnação e evolução econômica smithiana, sem que se prescindisse da demonstração da análise: "O próprio preço natural varia juntamente com a taxa natural de cada um dos componentes: salários, lucro e renda da terra; e em cada sociedade, essa taxa varia de acordo com as circunstâncias, sua riqueza ou pobreza, sua condição de economia em progresso, estacionária ou declinante" ([1776] 1996, p. 116); "Talvez, porém, nenhum país tenha ainda chegado a esse grau de opulência. A China parece ter permanecido estacionária por muito tempo [...]” ([1776] 1996, p. 143); “Ao que parece, a proporção entre os diferentes níveis salariais e de lucro, nos diferentes empregos de mão de obra e de capital, não é muito afetada - como já observei - pela riqueza ou pobreza de uma sociedade ou pela sua condição de progresso, estacionária ou de declínio" ([1776]1996, p. 184); "A frequência da emigração da Escócia, e a raridade da emigração da Inglaterra demonstram suficientemente que a demanda de mão de obra nos dois países é muito diferente. A proporção entre a remuneração real do trabalho em países diferentes importa relembrar - é naturalmente regulada, não pela riqueza ou pobreza efetiva, mas pelo seu estado de progresso, de declínio, ou pela sua situação estacionária" ([1776]1996, p. 224).
} 
alguns eventos circunscritos nas práticas econômicas, como o congelamento de preços e salários, a falta de investimentos e a imobilidade social.

Ainda assim, para que todo esse percurso gerativo mantenha seu funcionamento, há a operacionalidade de outro quadrado de valores coexistente a esse, e que também é tão fundamental quanto para o corpus de análise, quiçá para a obra de Adam Smith: os meios de produção.

\subsubsection{O mercantilismo disfórico}

Há na obra de Adam Smith uma poderosa força semântica outra, articulada nesta instância profunda da análise, e que orienta seu próprio percurso por debaixo de todo esse construto textual. Acerca dessa categoria, tratada em termos semióticos como uma força tímico-fórica ${ }^{22}$, é ela a mantenedora do grande termo complexo de A Riqueza das Nações: /trabalho/.

O trabalho é tratado pelo autor como o fim e o meio de toda nação que se estabelece minimamente de acordo com uma sociedade de produção, seja ela a mais primitiva ou mais evoluída: "O trabalho anual de cada nação constitui o fundo que originalmente lhe fornece todos os bens necessários e os confortos materiais [...]” (SMITH, [1776] 1996, p.59) assim introduz sua obra o pai da economia-política.

$\mathrm{Na}$ continuidade da esteira de seu pensamento, para se alcançar um alto nível de sofisticação e produção das mais variadas formas, e com isso uma elevação dos resultados das metas, é necessária então uma nova maneira de organizar os meios de produção. Eis o surgimento da lógica da Divisão do Trabalho (DIT), baseada, principalmente, numa ideia de superprodução manufatureira de bens, em que, ao invés de todo o processo produtivo do objeto se concentrar nas mãos de um e outro agricultor ou artesão, quando muito de uma família, passasse então a ser fragmentado na linha de produção de dezenas/ centenas de trabalhadores.

A partir daí se tem a primeira articulação do termo complexo /trabalho/, os termos contrários /S1 vs. S2/ assumidos como /difusão vs. especialização/, os quais, para colocar em termos didáticos, representam respectivamente a dissolução de um fazer e de um saber frente à concentração destes.

\footnotetext{
22 A categoria tímico-fórica determina, na instância fundamental, as categorias semânticas dos textos em exame (BARROS, 2002, p. 48).
} 
Seguindo a lógica do quadrado de primeira geração, advém, portanto, os termos /ñS1 vs. ñS2/, assumidos como uma /não-difusão vs. não-concentração/:

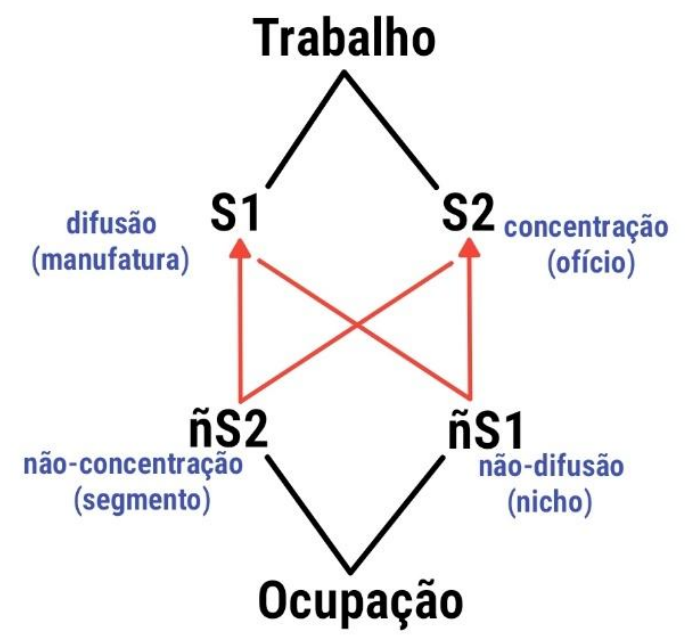

De igual forma ao primeiro quadrado proposto, há, portanto, dois eixos relacionais contraditórios que dizem respeito ao movimento em direção à especialização, assumidos, cada qual, como um contra-movimento de uma categoria semântica do /artesão/ (S1 $\square \tilde{n} S 1)$ e, inversamente, do /operário/ (S2 $\square \tilde{\text { ñS2}} 2)$.

No mesmo sentido, projetam-se as duas dêixis responsáveis pela instauração de sua própria divisa fórica e disfórica, constituídas por /S1 + ñS2/ e /S2 + ñS1/, tratadas através do binômio taxonômico /Liberalismo/ e /Mercantilismo/. Escolheu-se esse par de categorias não por acaso, pois, além de pesquisadores ${ }^{23}$ e especialistas da área ratificarem um caráter crítico subjacente na leitura de Smith sobre o então sistema econômico europeu vigente colonizador e limitador, há uma causalidade ipso facto óbvia desse viés disfórico do mercantilismo, operacionalizada na infraestrutura semântica geral da obra. Essa crítica, que se constrói na estrutura semântica elementar do sentido de ARN, faz jus ao próprio gênero de seu livro, considerado como uma crítica da ordem dos estudos de Economia Política.

O mercantilismo foi um sistema econômico vigente típico dos países em ascensão da Europa moderna, o que ficou ainda mais comprovado através do corpus reunido para esta análise.

\footnotetext{
${ }^{23}$ Vide Mattos, L. V. (2007), professora da FEA/USP e Bianchi \& Santos (2007), professora da FEA/USP e mestre pelo IPE-USP (Instituto de Pesquisas Econômicas da Universidade de São Paulo) respectivamente.
} 
Sobre essa dêixis dos valores mercantis do trabalho, e de sua estagnação enriquecidas pelas categorias do /nicho/ e da /ofício/, Smith procura esclarecer seu enunciatário acerca dos empecilhos criados por essa espécie de engessamento da força de trabalho, na contramão da DIT:

Tudo o que dificulta a livre circulação de mão de obra de uma profissão para outra, dificulta igualmente a circulação do capital de um emprego para outro, uma vez suprarealidade que o volume de capital que se pode aplicar em determinado setor depende muito da quantidade de mão de obra que o setor pode empregar. Todavia, as leis das corporações criam obstáculos menos à livre circulação de capital de um emprego para outro, do que à livre circulação da mão de obra. (SMITH, [1776] 1996, p.178)

A fim de se demonstrar ainda mais como que esse sentido irrompe na sua manifestação textualizada, no livro IV, Sistema de Economia Política, capítulo II, há uma das mais emblemáticas passagens que tratam justamente desse monopolismo praticado, muitas vezes, por uma casta de comerciantes delimitados e até mesmo mancomunados pelas chamadas corporações de ofício, herdadas das relações comerciais medievais, em que grupos de artesãos e trabalhadores centralizados na totalidade de sua produção determinavam, junto às autoridades e legisladores da época, os preços e as condições legais da prática de suas atividades:

Não cabe dúvida de que esse monopólio do mercado interno muitas vezes dá grande estímulo àquele tipo específico de indústria que se beneficia dele, e muitas vezes canaliza para ela um contingente maior de mão-deobra e de capital da sociedade do que o que de outra forma teria sido empregado nela. Entretanto, talvez não seja igualmente evidente que tal monopólio tende a aumentar a atividade gerada pela sociedade ou a darlhe a direção mais vantajosa. (SMITH [1776] 1996, p. 435)

Vem-se à tona na análise a dêixis disforizante /ñS1 + S2/ composta pela articulação sintáxica dos valores /nicho/ e /especialização/.

No contexto da obra, então, o termo $/$ nicho/ ${ }^{24} 25$ se refere a um segmento específico do mercado, representado por funções complexas na totalidade de sua atribuição, como

\footnotetext{
${ }^{24}$ Além de sua acepção lexical, o termo foi escolhido baseado nas teorias do marketing do conceituado professor e especialista em marketing Philip Kottler (1997), que assume nicho como "um grupo definido mais estritamente, um mercado pequeno cujas necessidades não estão sendo totalmente satisfeitas".

${ }^{25}$ Philip Kottler é mestre em Economia pela Universidade de Chicago, pós-doutor em Matemática e ciências comportamentais pela mesma universidade, e professor universitário. Autor de livros consagrados nas áreas de marketing e análise de mercado como Marketing Essencial: Conceitos Estratégias e Casos e Marketing de A a Z: 80 Conceitos que Todo Profissional Deve Saber.(2003).
} 
ourives, ferreiro, alfaiate, sapateiro, dentre outros. O agrupamento de tais classes, mediante decretos, sanções jurídicas e de caráter restritivo e monopolista se dá pelo valor /ofício/, completando finalmente a estrutura dêitica sob a taxonomia do signo-valor /Mercantilismo/.

Projetam-se, portanto, os dois grandes e principais microssistemas representativos das estruturas fundantes do corpus de análise e, quiçá, de ARN. Ambos os quadrados semióticos são orientados por um sujeito que participa de todo esse esquema de sentido, consubstanciado como Nação, através de um percurso de afirmações e negações que acabam por reunir duas grandes oposições:

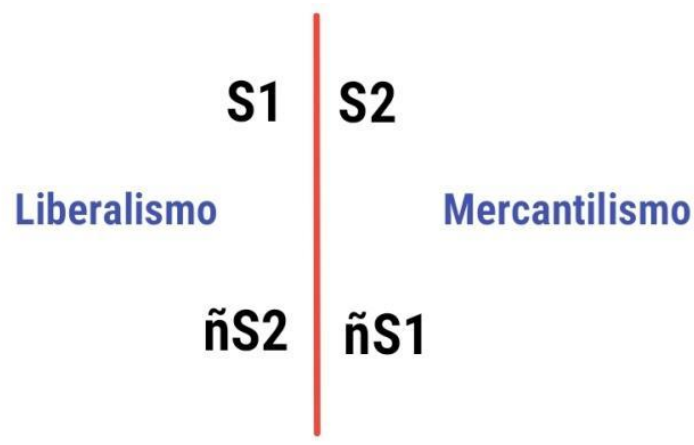

O status quo mercantilista persistia naquela Inglaterra às voltas com um sistema econômico atrasado, parasitário e manchado por lutas e conquistas questionáveis até mesmo pelo ponto de vista humanitário, sem se entrar na seara econômica ou ideológica. $\mathrm{O}$ próprio enunciador coloca em cheque a Companhia Britânica das Índias Orientais ${ }^{26}$ :

Prevaleceriam imediatamente, nessa classe, a carência, a fome e a mortalidade [...] Esse é talvez, aproximadamente, o estado atual de Bengala, e de algumas outras colônias inglesas nas Índias Orientais. [...] A diferença entre o caráter da Constituição britânica, que protege e governa a América do Norte, e o da Companhia Mercantil, que oprime e domina as Índias Orientais, não poderia talvez ser mais bem ilustrado do que pela diversidade das condições desses dois países. (SMITH, [1776] 1996, p. 124)

\footnotetext{
${ }^{26}$ Para se entender ainda mais o contexto histórico que perfaz esse excerto, Marx publicou um artigo que ilustra bem essa divisão operada entre a administração direta da coroa britânica de determinadas colônias, dentre elas, os Estados Unidos, e a gestão de outras pela própria Cia. das Índias: "Mas a Companhia das Índias Orientais, em lugar de cumprir seu compromisso, em lugar de pagar um tributo à nação inglesa, encontrava-se prisioneira de dificuldades financeiras, fazendo um apelo ao Parlamento para dele obter uma ajuda pecuniária. A consequência desse encaminhamento foi sérias modificações na Carta. Os negócios da Companhia não melhoraram a despeito de sua nova condição, e para a nação inglesa, tendo ao mesmo tempo perdido suas colônias na América do Norte, fez-se sentir mais e mais universalmente a necessidade de conquistar em outros lugares um vasto império colonial. (MARX, 1853, p.02)".
} 
O todo semântico do projeto smithiano se constitui, assim, desse par de oposições extremamente propositivo para o sentido principal de sua obra: para se obter sucesso, uma nação deve ser ativa e dinâmica economicamente, além de sedimentada numa lógica de mercado em que a divisão e a reorganização segmentada e fragmentada das relações do próprio trabalho são fundamentais para a inserção - dado o contexto histórico da obra - e a manutenção desse status dito liberal.

A fim de que se finalize com um excerto peculiar do capítulo "Conclusão da digressão sobre as variações do valor da prata" (p. 262-267), do livro I, por seu caráter direto e sucinto de tal oposição tratada no nível fundamental, eis uma das passagens mais objetivas e descritivas da referida asserção deste momento da análise, em que o enunciador emite uma sanção negativa de uma não-relação entre aumento da quantidade de metais e a produção agrícola e industrial em seu continente:

O aumento da quantidade de ouro e prata na Europa e o aumento de suas manufaturas e de sua agricultura constituem dois eventos que, embora tenham ocorrido mais ou menos ao mesmo tempo, derivam de causas muito diferentes e dificilmente apresentam alguma correlação entre si. [...] Apesar disso, esse aumento da quantidade dos metais preciosos parece não ter aumentado a produção anual, nem desenvolveu a manufatura e a agricultura do país, nem melhorou as condições de seus habitantes. (SMITH, [1776] 1996, p. 263).

O mercantilismo, assim, é considerado pouco inteligente e, tanto pior, um fator de atraso e decadência das nações que ainda se submetiam a esse tipo de prática, tanto por conta do metalismo, quanto pelas relações impostas em seus regimes de trabalho e produção de bens e serviços.

\subsection{Da metalinguagem da Semiótica à metalinguagem da Economia}

Com intuito de se dar mais clareza ao termo da Economia, o liberalismo é entendido basicamente como "doutrina que serviu de substrato ideológico às revoluções antiabsolutistas que ocorreram na Europa (Inglaterra e França, basicamente) ao longo dos séculos XVII e XVIII", e mais, “[tem] a livre iniciativa e a concorrência como princípios básicos capazes de harmonizar os interesses individuais e coletivos e gerar o progresso social” (SANDRONI, 1999, p. 347). A ideologia liberal nasce em um ambiente restrito por reis \& leis, os quais empunhavam a centralização de seus poderes com uma mão de ferro 
nada invisível, num estilo de governança feita por instrumentação de super decretos, característica esta do absolutismo e de regimes autoritários, diga-se, mesmo séculos depois.

Voltando ao ambiente da análise, e focalizando tão somente e estritamente os meios de produção e o seu modo de equacionar as relações de trabalho numa sociedade de mercado, o quadrado semiótico greimasiano demonstra que esse laissez-faire das trocas, através da Divisão do Trabalho, possui como substrato semântico a noção de fragmentação e delimitação da relação dos homens com seus objetos. Essa mesma lógica operante, de características delimitadora e restritiva, da fratura múltipla do corpo de um sujeito que sente e modifica seu meio, parece não somente se resguardar sob os limites do calor da fornalha e do chão sujo de fábrica, como também das relações que orientam a ideologia liberal como um todo.

Acerca dessas características fragmentárias e limitantes do turno e das ações dos trabalhadores, Thomas Sowell ${ }^{27}$, em sua obra Conflito de Visões (2007), procura demonstrar os germens do pensamento conservador e progressista, estabelecendo para isso uma divisão metodológico-pedagógica para que se compreenda mais e melhor ambos os lados, classificando-os como visão restrita e visão irrestrita de mundo, respectivamente. $\mathrm{O}$ autor arrola, para tal fim, dados e estudos nos mais variados campos, como jurídico, administrativo, político e comportamental.

Ao investigar as nuances e as fronteiras mais visíveis de cada lado, no que diz respeito à Economia - diga-se, sua área de especialidade - Sowell apresenta o pensamento de Adam Smith partindo da premissa de que essa divisão/fragmentação do trabalho, a qual está diretamente inserida num sistema econômico que, por conseguinte, faz parte das práticas adotadas por políticas mais à direita do espectro sociopolítico, seria uma espécie de ponto de apoio de Arquimedes para a resolução de um problema intrínseco da capacidade que o ser humano tem de pensar mais em si mesmo do que no outro:

Resumindo, esses conceitos foram vistos por Smith como o caminho mais eficaz de realizar o trabalho pelo menor custo psíquico. Apesar de ser uma questão moral, a resposta de Smith foi essencialmente econômica: um sistema de incentivos morais, um conjunto de trocas em vez de uma solução real para mudar o homem. Uma das marcas da visão restrita é que ela lida mais com as trocas do que com soluções. (SOWELL, [2007] 2012, p. 27)

\footnotetext{
27 Professor de Economia em Cornwell, UCLA, Amherst e outras instituições universitárias, é atualmente um membro do Instituto Hoover, da Universidade de Stanford.
} 
Segundo a lógica smithiana, estabelecer a Divisão do Trabalho, fragmentando os processos, é estabelecer a necessidade sintáxica da troca e da interdependência, e o estímulo do fazer da troca é pedra angular do grande sistema discursivo liberal. Nas palavras do próprio enunciador:

Uma vez plenamente estabelecida a divisão do trabalho, é muito reduzida a parcela de necessidades humanas que pode ser atendida pela produção individual do próprio trabalhador. A grande maioria de suas necessidades, ele a satisfaz permutando aquela parcela do produto de seu trabalho que ultrapassa o seu próprio consumo, por aquelas parcelas da produção alheia de que tiver necessidade. (SMITH, [1776] 1996, p. 81)

Uma parcial conclusão, que a teoria auxilia na análise de Adam Smith, a partir do conteúdo semântico mais profundo da obra, é esse caráter fragmentário e particionário dos mais variados sujeitos semióticos, delimitando que cada qual busque seus objetos e, no final de tudo, todos estarão alinhados num objeto maior, de caráter mais complexo e, por isso mesmo, mais abrangente, o bem estar de cada indivíduo.

Portanto, a semiótica de Greimas, com suas inúmeras ferramentas de análise, guardadas e questionadas suas devidas limitações pode, sem sombra de dúvida, auxiliar na compreensão das significações que se depositam debaixo das mais variadas e complexas áreas tão ricas e técnicas como a Economia.

\subsection{Entre o profundo e o narrativo: no limiar da conversão dos níveis}

Assim como a forma do gênero "dissertação acadêmica" possui estratégias de passagem e progressão de temas, tópicos e parágrafos em sua produção textual, convertendo elementos explícitos e implícitos para uma boa condução do assunto em questão, seria ingenuidade pensar que a semiótica greimasiana não postulasse uma conversão $^{28}$ de níveis tal e qual a forma manifestante do texto.

Greimas, ao pensar na quadratura do seu modelo representativo de nível profundo do percurso de sentido, aplicável em todo e qualquer suporte de significação, coloca em

\footnotetext{
28 "Há de ser lembrado que pelo nome conversão designamos o conjunto de procedimentos que explicam a passagem (= transcrição) de uma unidade semiótica situada no nível profundo para uma unidade da estrutura de superfície, sendo essa nova unidade considerada, ao mesmo tempo, homotópica e heteromorfa em relação à antiga, isto é, como enquadrando o mesmo conteúdo tópico e contendo mais articulações significantes, sintáticas e/ou propriamente semânticas". (GREIMAS, [1983] 2014, p.104).
} 
jogo termos contrários em duas grandes categorias semânticas, articulando dois grandes signos nas descendências dos contraditórios e nas ascendências dos complementares. Nada mais são do que termos semânticos primitivos que, por conta mesmo desse caráter, operam num jogo de asserções e negações "simples", sem que exista necessariamente uma "autoria subjetiva" em tal percurso.

Para que essa articulação do significado mais primitivo se converta em níveis mais próximos da matéria complexa manifestada na superfície do texto, o mestre lituâno empresta para sua teoria o conceito de timia, a qual trata de uma readaptação daqueles semas mais profundos em uma projeção axiológica, ou seja, de valores in absentia, operacionalizados no quadrado, de modo que se assuma as duas dêixis fóricas, passando a ser operacionalizadas em uma ideologia assumida por um corpo que sente (leia-se, sujeito!) num nível ${ }^{29}$ imediatamente acima:

O espaço tímico que, no nível das estruturas abstratas, supostamente representa as manifestações elementares do ser vivo em relação a seu meio ambiente (conforme acima/animado/) encontra sua correspondência, no nível mais superficial, antropomórfico, do percurso gerativo, no espaço modal que, embora recubra o mesmo lugar tópico, se apresenta como uma excrescência e como uma sobrearticulação do primeiro (e pode ser aproximado do termo /humano/). (GREIMAS, [1983] 2014, p. 105)

Falar dessa homotopia e heteromorfia situada por Greimas é justamente propor um sentido subjacente que, numa instância superior, encontra-se mapeado analogamente aos "lugares" por onde trilha o sujeito diante de seu objeto, para isso, assumindo uma forma outra, criada na relação sujeito/ objeto, actantes ora modalizados ora modalizadores nas instâncias sintáxicas do plano narrativo.

Uma vez apresentadas as dêixis com a investidura tímica dos valores "bons" e "ruins", em relação a sujeitos e objetos - seja um enunciador que quer apresentar sua teoria liberal a um enunciatário, ou um trabalhador que quer fabricar o motor de um veículo na linha de montagem - eis o momento de se prosseguir a análise para a próxima etapa do texto.

\footnotetext{
${ }^{29}$ Benveniste também apresenta essa amarra dos níveis superiores e inferiores ao analisar os fonemas e os merismas, o que corrobora ainda mais para a sedimentação da teoria greimasiana de conversão dos níveis: "A noção de nível parece-nos essencial na determinação do procedimento de análise. Só ela é própria para fazer justiça à natureza articulada da linguagem e ao caráter discreto dos seus elementos; só ela pode fazer-nos reconhecer, na complexidade das formas, a arquitetura singular das partes e do todo". (BENVENISTE, [1976] 2005, p. 127).
} 


\subsection{Nível Narrativo}

\subsubsection{F = Trabalho}

Adam Smith faz a abertura do primeiro capítulo do Livro I de ARN alegando ser a força da mão de obra, “o trabalho anual”, a responsável pela aquisição dos mais diversos bens de um país (nação). Essa força constrói o chamado fundo (fund), que é dividido de duas formas: 1. a produção (produce) dos bens e serviços diretos - "imediata" - necessários para o consumo e estoque do próprio povo; 2. a produção dos bens e serviços que são comprados de outros povos. Segue o excerto:

O trabalho anual de cada nação constitui o fundo que originalmente lhe fornece todos os bens necessários e os confortos materiais que consome anualmente. $\mathrm{O}$ mencionado fundo consiste sempre na produção imediata do referido trabalho ou naquilo que com essa produção é comprado de outras nações. (SMITH, [1776] 1996, p. 59) ${ }^{30}$

Em relação ao excerto acima, verifica-se um enunciado elementar de estado (BARROS, 2002, p. 29-30) que se dá pela junção entre o objeto (bens) e o sujeito figurativizado como nação:

\section{F junção $(S, 0)$ \\ (Nação) (Riqueza)}

Chama-se enunciado elementar esse corte linguístico o qual estabelece uma relação entre dois funtivos ${ }^{31}$ actanciais do nível narrativo, no caso, $F$ estabelece uma função juntiva, seja ela de conjunção ou disjunção entre um sujeito e um objeto.

Ainda sobre o referido trecho de A. Smith, percebe-se um enunciado que manifesta temas como "trabalho" e "produção", narrativamente responsáveis pela aquisição do objeto pelo sujeito, demonstrado através da figuratividade do verbo "consumir", que postula uma relação de posse entre os actantes, postos numa relação predicativa realizante:

\footnotetext{
${ }^{30}$ Trecho para efeito de observação sobre o verbo $\operatorname{ser}(i s)$ no original: "the annual labor of every nation is the fund which originally supplies it with all the necessaries and conveniences of life which it annually consumes, and which consist always either in the immediate produce of that labour, or in what is purchased with that produce from other nations" (SMITH, 1776, p. 04).

${ }^{31}$ Segundo Hjelmslev, "Serão denominados funtivos de uma função os termos entre os quais esta existe, entendendo-se por funtivo um objeto que tem uma função em relação a outros objetos"([1943] 2006, p. 39).
} 


\section{$S \cap 0 v$ \\ (Nação) consumir (Bens)}

Entretanto, para que o estado conjuntivo do enunciado acima se dê, o autor refere-se a mais um novo elemento ativo dessa "produção", o que acaba por revelar um novo sintagma narrativo para a exposição:

[...] a abundância ou escassez de seu [nação] suprimento anual depende necessariamente, enquanto durar esse estado de coisas, da proporção entre o número dos que anualmente executam um trabalho útil e o daqueles que não executam tal trabalho. (SMITH, [1776] 1996, p. 60)

De súbito é possível visualizar um segundo actante por conta da perífrase, "aqueles que executam o trabalho útil", chamado arbitrariamente para esta análise - mas não casualmente - de trabalhador, que sustenta uma relação de dependência entre o "estado de coisas", ou seja, aquele consumo de bens, e a nação, graças ao fazer do seu "trabalho útil".

Assim, tratando-se das questões do nível narrativo, vislumbra-se um "fazer" futuro, típico dos programas narrativos de transformação que dão conta da passagem de um estado juntivo a outro (GREIMAS; COURTÉS; [1986] 2008 p. 170), ou mais especificamente ainda, de um programa narrativo de base ${ }^{32}$ modalizando o enunciado descritivo. A título de organização da apresentação do trabalho, por ora, entenda-se que valores modais são aqueles que modificam outros enunciados, e descritivos, aqueles que expressam uma grandeza semântica em estado puro (GREIMAS [1983] 2014, p. 112):

\begin{tabular}{|c|c|c|}
\hline & $\begin{array}{l}\text { Enunciado Elementar } \\
\text { F junção }(\mathbf{S}, \mathbf{0}) \\
\text { (Naça) (Riqueza) }\end{array}$ & \\
\hline $\begin{array}{l}\text { Enunciado de Estado } \\
\qquad \mathrm{S} \cup \mathrm{Ov}\end{array}$ & $\begin{aligned} \text { PN de Base }=\mathrm{F}[\mathrm{S} 1 \mathrm{a} & \rightarrow(\mathrm{S} 2 \mathrm{~b} \cup \mathrm{Ov})] \\
\mathrm{F}[\mathrm{S} 1 \mathrm{a} & \rightarrow(\mathrm{S} 2 \mathrm{~b} \cap \mathrm{Ov})]\end{aligned}$ & $\begin{array}{l}\text { Enunciado de Estado } \\
\qquad \mathrm{S} \cap \mathrm{Ov}\end{array}$ \\
\hline
\end{tabular}

\footnotetext{
32 Os programas são, em geral, complexos, constituídos por mais de um programa, hierarquizados: um programa narrativo de base, que exige a realização prévia de outros programas, pressupostos, denominados programas narrativos de uso e cujo número depende da maior ou menor complexidade da tarefa a ser executada. (BARROS, 2002, 33).
} 
O programa narrativo (PN) é caracterizado da seguinte maneira (BARROS, 2002, p. 32-33): a natureza da junção, se, por exemplo, de conjunção; o valor investido, modal ou descritivo; a complexidade do programa; e a relação entre os sujeitos, se autônomos ou sincréticos. Com relação a essa partição tipológica, entretanto, o estudo a demonstrará no capítulo Do investidor. Para o momento, é necessário notar-se que o PN é uma espécie de macro-enunciado que rege e pode ser regido por demais programas dentro do grande esquema narrativo englobante dos diversos percursos de seus múltiplos actantes, estabelecendo funções entre os sujeitos e seu objeto através de suas relações sintagmáticas e paradigmáticas ${ }^{33}$.

Assim, se entende a tão aludida circularidade a partir dessa produção de bens (riqueza), e assim se consegue chegar àquilo que o próprio autor chama de "excedente", essencial à saúde econômica de um país pelas lentes de sua teoria.

\subsubsection{O capital excedente}

Ao construir as bases e as estruturas sustentadoras de sua teoria, Smith alega que a permuta se trata de uma prática bastante antiga entre as sociedades, além de ser responsável por outro pilar de seu pensamento, a Divisão do Trabalho, analisada mais adiante. A extensão do mercado é diretamente influenciada pela extensão das trocas realizadas no seu interior (SMITH, [1776] 1996, p. 77).

Essa permuta possibilita a "troca" do produto excedente entre as partes interessadas, pois, uma vez supridas, por exemplo, as necessidades de calçados de um sapateiro, seja com um, dois, ou até dez pares de sapato, o sujeito artesão precisa ainda dar conta de outras necessidades, como a alimentar, a de higiene pessoal, e nem por isso produzirá o próprio pão ou sabão:

Assim como é por negociação, por escambo ou por compra que conseguimos uns dos outros a maior parte dos serviços recíprocos de que necessitamos, da mesma forma é essa mesma propensão ou tendência a permutar que originalmente gera a divisão do trabalho. (SMITH, [1776] 1996, p. 74)

\footnotetext{
33 Quando, numa sequência de enunciados, os sujeitos são os mesmos em relação ao objeto, as junções se dão sintagmaticamente; de outro modo, a natureza da junção se constrói paradigmaticamente quando, em um único enunciado, os sujeitos da disjunção e da conjunção são distintos (GREIMAS, [1983] 2014, p. 46).
} 
Vislumbra-se daí outro programa narrativo de caráter mais privado, em que o sujeito precisa estar de posse de determinado objeto para que se troque pelo objeto de outro sujeito, num tipo de relação transitiva entre actantes. Cada sujeito, em seu turno, alterna sua função em relação aos objetos para que a troca se estabeleça e haja uma transformação nos enunciados de estado de cada um.

Assim, quando a transformação de um sujeito se dá pela renúncia, concomitantemente a do outro é a atribuição ${ }^{34}$ e vice-versa, caracterizando-se o PN da troca:

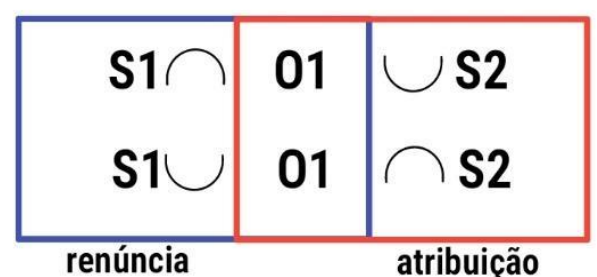

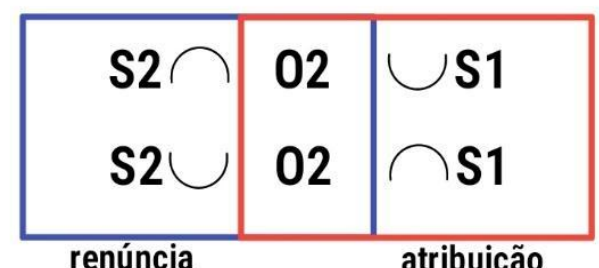

atribuição

Ao final, esse intercâmbio vai ocorrer em proporções inúmeras, entre vários sujeitos, de modo a produzir automaticamente uma espécie de resíduo daqueles objetos, chamado pelo enunciador de "excedente", o qual será diretamente responsável pela produção de três tipos de objetos fundamentais nas relações actanciais apresentadas mais adiante: o salário, a renda da terra e o lucro.

\subsubsection{Salário, Lucro e Renda: objetos capitais}

O livro primeiro, As Causas do Aprimoramento das Forças Produtivas do Trabalho e a Ordem Segundo a qual sua Produção é Naturalmente Distribuída Entre as Diversas Categorias do Povo, sobre o qual a análise se debruça de maneira mais aprofundada, é indubitavelmente o livro que tem por finalidade categorizar e organizar os agentes, os instrumentos e os meios de produção daquele Mundo Moderno contemporâneo ao autor. Exatamente por conta desse caráter introdutório e de seu estabelecimento de dados e informações essenciais para o restante dos demais quatro livros que compõem a obra, a análise conseguiu extrair desse referido corpus os recortes que abordam os diferentes atores responsáveis pela produção $(\mathrm{F})$ direta e indireta da riqueza de uma nação.

34 Greimas [1983] 2014, P.49. 
Isso é demonstrado no capítulo IV, Fatores que Compõe o Preço das Mercadorias, por uma relação causal dos três tipos de renda de que um país precisa para se sustentar:

Assim como o preço ou valor de troca de cada mercadoria específica, considerada isoladamente, se decompõe em algum dos três itens ou nos três conjuntamente, da mesma forma o preço ou valor de troca de todas as mercadorias que constituem a renda anual completa de um país considerando-se as mercadorias em seu complexo total - deve decompor-se nos mesmos três itens [...] Salários, lucro e renda da terra, eis as três fontes originais de toda receita ou renda, e de todo valor de troca. Qualquer outra receita ou renda provém, em última análise, de um ou de outro desses três fatores. (SMITH, [1776], 1996, p. 105)

Compreende-se, então, uma transitividade entre actantes de modo a conferir-lhes existência: os três tipos de objeto para três tipos de sujeitos, determinados pelo próprio discurso da obra: o senhor de terras, o investidor (empresário) e o trabalhador. Doravante actantes, ao senhor de terras lhe é reservado um sincretismo actancial ${ }^{35}$ como Destinador e sujeito; ao investidor uma função actancial como, em relação ao senhor de terras, destinatário-sujeito; em relação ao trabalhador, destinador; e, como já apresentado preliminarmente, o trabalhador do discurso smithiano desempenha sua "previsível" função de sujeito na equação narrativa greimasiana. Portanto, há os seguintes sujeitos e objetos postos:

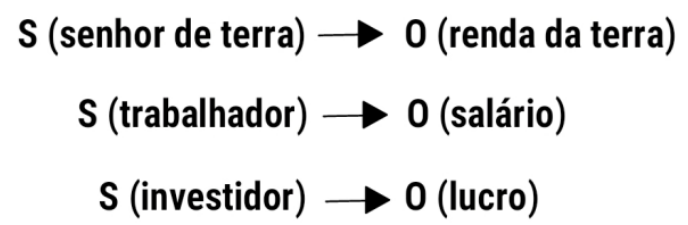

Adiante, nos demais capítulos, procurar-se-á mostrar como se dão os percursos de cada actante dentro de seus programas e como chegam aos seus objetos, selecionando para isso os vários percursos textualizados a partir das perspectivas escolhidas pelo enunciador na organização sintagmática de seus programas narrativos (GREIMAS; COURTÉS, [1986] 2008, p. 367).

${ }^{35}$ Tatit, 2001, p. 47 


\subsubsection{A(s) performance(s) do sujeito sincrético "senhor da terra"}

No Capítulo XI, A Renda da Terra, o autor discute acerca das cláusulas várias, percentuais e situações contemporâneas a ele que demonstram as particularidades sobre o tema central descrito no título capitular. Tal renda representa aquilo que o proprietário de terras úteis aufere como ganho, basicamente, do valor da locação de seu espaço e do produto que dela se cultiva:

A renda da terra, considerada como o preço pago pelo uso da terra, é
naturalmente a maior que o arrendatário pode permitir-se pagar, nas
circunstâncias efetivas da terra. [...] Toda e qualquer parcela da produção
ou - o que é a mesma coisa - toda parcela do preço da produção que
ultrapasse a porcentagem destinada ao arrendatário, o dono da terra
naturalmente procura reservá-la para si, como sendo a renda que lhe é
devida pelo uso da terra. (SMITH, [1776] 1996, p. 185)

Segundo o exposto, para que o sujeito (dono da terra) consiga estabelecer seu estado conjuntivo com seu objeto (renda),

\section{Enunciado de Estado \\ $\mathrm{S} \cap 0 \mathrm{v}$ \\ S: senhor de terras 0 : renda da terra}

é preciso que este faça outro sujeito (arrendatário) produzir em sua área de cultivo:

[...] o dono da terra faz o possível para deixar ao arrendatário uma parcela da produção não superior ao que é suficiente para pagar ao arrendatário o capital do qual ele fornece as sementes, paga a mão-de-obra, compra e mantém o gado e outros instrumentos e dispositivos agrícolas, juntamente com o lucro normal do capital empregado, segundo a taxa vigente na região. Evidentemente, isso é o mínimo com o qual o arrendatário pode contentar-se, se não quiser sair perdendo no negócio. (SMITH, [1776] 1996, p. 185)

Percebe-se aí um terceiro actante "investidor" que quer produzir - pois seu fim é, obviamente, obter seu lucro - mas não pode, por conta da privação de um espaço para sua cultura e/ou manufatura. Instala-se, portanto, num primeiro momento, o papel actancial do Destinatário-sujeito através da figura do "investidor". Destinatário-sujeito por razões 
semânticas, sintáticas e paradigmáticas: (i) semântica, por carecer de valores modais necessários para a obtenção de outro objeto de valor, como capacidade, sabedoria, força, etc. isto é, do ponto de vista da relação do signo saussureano (SAUSSURE, [1916] 2006, p. 143); (ii) sintática (in praesentia), por estabelecer uma relação direta com outro actante num mesmo programa narrativo de manipulação ${ }^{36}$; (iii) paradigmática (in absentia), por participar de um enunciado de estado disjuntivo acerca de um mesmo objeto projetado em um enunciado de estado conjuntivo concomitante.

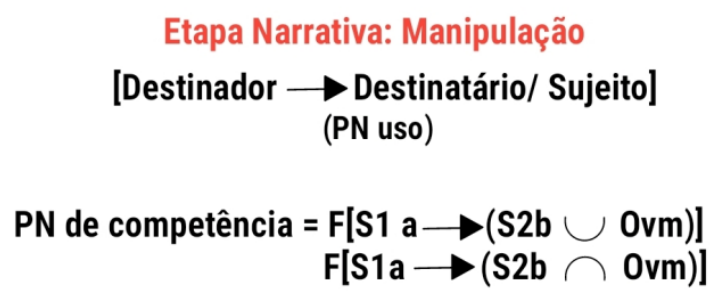

F: arrendar (fazer-poder-fazer) S1a: Destinador senhor de terras S2b: Destinatário/Sujeito arrendatário Ovm: produzir (poder-fazer)

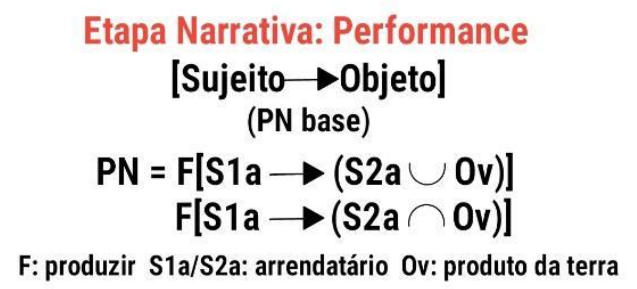

Portanto, o Destinador "dono de terra" manipula-o para que este se torne um arrendatário de fato, ou seja, um sujeito modalizado para a etapa seguinte de seu esquema narrativo, aquele que aluga uma porção da terra - e que, consequentemente, atualize-a através de seu fazer pragmático ${ }^{37}$ durante sua performance, dos valores de "fertilidade" para "utilidade", "produtividade" do solo, e dele extrair seu produto. O Destinador estabelece, portanto, uma comunicação manipulativa (fazer-fazer) direta com seu destinatário de modo a contribuir para a efetivação de seu sucesso no percurso seguinte.

Parafraseando Tatit, (2010, p. 92), é a função do destinador, ativo do ponto de vista sintáxico, que desencadeia a ação de seu destinatário-sujeito para, na busca de seu objeto, manterem-se despertos os pontos vitais garantidores do êxito da narrativa.

\footnotetext{
36 “A aproximação entre a manipulação e a aquisição de competência é particularmente esclarecedora, especialmente porque põe em evidência dois tipos diferentes de intencionalidade. Graças à manipulação, o Destinador negocia a passagem do Destinatário à ação, isto é, sua conversão em Sujeito" (FONTANILLE, 2015, p. 122).

37 Segundo Tatit (2001, p. 58), o fazer pragmático descreve as esferas de ação somatizadas graças às qualidades (competências) de seus actantes.
} 
Trazer para a análise esse pequeno recorte do esquema narrativo do sujeito “arrendatário" serve para demonstrar que, sob outra perspectiva ${ }^{38}$, todas as suas etapas e, consequentemente, programas, nada mais são que uma série de programas narrativos de uso para outra etapa performática dentro do esquema narrativo do senhor de terras, no qual é sujeito. Segundo o próprio Dicionário de Semiótica (COURTÉS \& GREIMAS, [1986] 2008 , p. 390), o PN de uso pode ser realizado seja pelo próprio sujeito, seja por outro sujeito sobremodalizado, ou seja, delegado pelo primeiro: nesse caso, diz-se de PN programa narrativo - anexo, reconhecido como pertencente a um nível de derivação inferior:

\section{Etapa Narrativa: Performance}

(PN anexo)

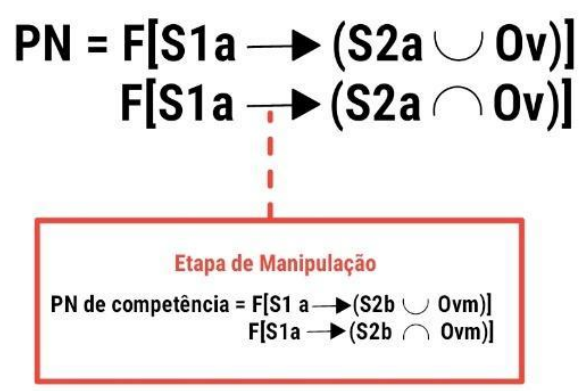

\section{F: arrendar S1a/S2a: senhor de terras Ov: renda da terra}

Uma vez arrendada a terra, o sujeito "senhor de terras" está atualizado para entrar em plena conjunção com seu objeto. Para explicitar melhor esse tipo de junção, Greimas ([1983] 2014, p. 48-49) fala sobre uma espécie de comunicação de valores entre sujeitos idênticos dentro de um mesmo programa narrativo, executando uma transformação do tipo realização reflexiva, identificado como apropriação.

Logo, ao se considerar os PNs constituintes dessa etapa performática e da etapa anterior, vê-se claramente que um mesmo ator configura, narrativamente, num primeiro momento, um papel actancial de Destinador que faz fazer dentro de um percurso da manipulação, o qual é, por sua vez, sobremodalizado por modalidades atualizantes do tipo saber-fazer (as regras e leis do arrendamento) e um poder-fazer (ter os instrumentos e a terra para o arrendamento). Esse mesmo actante, posteriormente, assume outro papel

\footnotetext{
${ }^{38}$ Greimas fala sobre a perspectiva ([1983] 2014, 47) como uma existência de dois programas narrativos correlacionados e explica por que uma mesma narrativa pode ser manifestada discursivamente - contada ou ouvida - explicitando-se ora um programa ora outro, mas sempre preservando, de forma implícita, o programa narrativo concomitante e inverso.
} 
actancial subjetal que faz-ser, ou seja, que altera seu estado em relação ao objeto. Essa transformação de estado ocorre por conta de uma performance do tipo fazer-ser, a qual se desdobra em todos aqueles demais programas narrativos anexados, estabelecendo assim uma função actancial temporária de Destinador.

Portanto, tal termo "senhor de terras" articula em um espaço homeotópico superior discursivo aqueles dois actantes narrativos em suas estruturas mais profundas, caracterizando assim o conceito de sincretismo demonstrado por Hjelmslev ([1943] 2006, p. 93), em que um termo hiperonômico, num nível linguístico superior, neutraliza outros dois termos, ou seja, um termo atorial do nível do discurso que articula dois papeis actanciais, ora de Destinador, ora de Sujeito, em nível narrativo, caracterizando, assim, um sincretismo atorial.

Um último dado: embora se tenha chegado a tal veredito nesta análise dos objetos de valor visados pelos diferentes sujeitos em seus diferentes percursos (sujeito: senhor de terras; objeto: renda da terra - sujeito: investidor; objeto: produto da terra), há ainda uma forte suspeita de que estariam, ambos os actantes, apontados para um único objeto de valor. Mesmo quando sintagmatizados na etapa de manipulação entre Destinador e Destinatário (Dor/Drio), o elemento actancial que os une parece ser exatamente a mesma grandeza objetal.

Para tornar um pouco mais didática a "muito provável ingênua suspeita”, Greimas, ao explicitar a comunicação de valores entre Dor e Drio, acaba, por um breve momento, postulando haver uma espécie de descompasso de interesses entre os sujeitos. Essa tal assimetria do desejo dos sujeitos só pode ser transformada em um querer simétrico, segundo o mestre semioticista, se o objeto a ser conquistado for de mesma natureza:

[...] é por isso que o estatuto paradigmático do destinador em relação ao destinatário se define pela relação hiperonímica, ao passo que a do destinatário em relação ao destinador se caracteriza pela relação hiponímica, sendo que essa assimetria só pode se acentuar quando da sintagmatização dos dois actantes, considerados sujeitos interessados por um único objeto. (GREIMAS [1983] 2014, p.56)

Embora seja possível perceber que, num olhar preliminar, e em nível figurativo, a renda da terra e o produto da terra assumem respectivamente termo pressuposto e pressuponente, tornados um distinto do outro, ao se observar pela perspectiva das relações sintáticas que os sujeitos estabelecem entre si e entre seus objetos, a distinção pode ficar pouco definida. 
Se forem tomadas as breves, contudo, precisas postulações de Greimas ([1983] 2014, p. 34) sobre a natureza do objeto, ter-se-ia: (i) os objetos só podem se tomar cognoscíveis em razão de suas determinações e não por si mesmos; (ii) essas determinações só podem ser apreendidas como diferenças que se projetam sobre o objeto, pois é esse caráter diferencial que lhes confere o estatuto de valor linguístico; (iii) mesmo permanecendo incognoscível enquanto tal, o objeto é, entretanto, pressuposto como uma espécie de suporte para a existência de valores.

Como já demonstrado anteriormente, enquanto para um é objeto de valor "fim" (ter algo) e para o outro é objeto modal de "instrumento" (produzir algo para ter algo), direta e indiretamente a mesma terra lhes proverá o segundo mais valioso bem da teoria liberal de Adam Smith: o dinheiro.

\subsubsection{Do investidor}

Ao se analisarem com atenção as grandezas que subjazem ao discurso smithiano, há um actante que aparece reiteradamente no corpus escolhido, e que se instala em relação direta com o sujeito "trabalhador" e com este contrai sua função: o Destinador $\left(D^{o r}\right)$ investidor.

Como já brevemente explicitado no capítulo anterior sobre o "senhor de terras", este funtivo narrativo se constrói por conta de uma função estabelecida entre dois actantes em que, de um lado, há uma comunicação de valores com fins de sobremodalizar o outro e agir sobre o homem (fazer-fazer), e, de outro, a recepção de tais valores de modo a agir sobre o mundo (fazer-ser). Para estreitar ainda mais o foco deste momento da análise sobre o $\mathrm{D}^{\text {or }}$, é importante mencionar que este aparece em dois momentos distintos no percurso do sujeito: na fase da manipulação e da sanção. Acerca da manipulação, Barros, define que:

No percurso do destinador-manipulador, o programa de competência é examinado não na perspectiva do sujeito de estado que recebe os valores modais, mas do ponto de vista do sujeito doador ou destinador desses valores, $\mathrm{O}$ destinador manipulador é o actante funcional que engloba vários papéis actanciais, entre os quais se encontra necessariamente o de sujeito doador de valores modais. (BARROS, 2005, p. 30)

Ainda segundo a própria autora, o percurso da manipulação é constituído por três "subetapas": a realização de um contrato fiduciário prévio; a persuasão do Destinador; e a 
aceitação ou recusa do $\mathrm{D}^{\text {ario }}$-sujeito. O contrato fiduciário é, basicamente, a etapa preliminar para a construção mínima da confiança (D ${ }^{\text {ario }}$ ) (BARROS, 2002, p. 38).

Essa confiança se dá também por conta da competencialização que o Dor exerce sobre o Drio por conta da sobremodalização de um ser-fazer através da competencialização do sujeito.

Só assim o sujeito, então investido de seu querer/dever ou de um poder/saber, é que segue em direção à performance, que será apresentada em capítulo à frente que trata da DIT (Divisão do Trabalho).

\subsubsection{F(Greimas, Texto)}

Para se compreender melhor sobre as transformações de sujeitos e objetos, é necessário que se retomem as bases: Greimas tratou dessas modalizações em seu Sobre o Sentido II, baseando-se nos estudos de áreas variadas da Linguística, da Lógica, e, a partir dessas, criou um sofisticado e complexo "cálculo de predicado dos enunciados", postulando a ideia de que todo enunciado é um ato, e que todo ato é per si, “aquilo que faz ser" ([1983] 2014, p. 80):

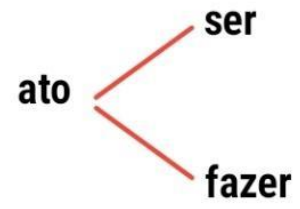

Fica proposto, assim, que todo enunciado elementar sempre terá dois actantes e será de dois tipos: fazeres ou de estados, sendo, respectivamente, enunciados de transformação e de junção:

\section{$\rightarrow$ Transformação (fazer) Junção (ser)}

Já se tem aí os denominadores mínimos para a construção de equações narrativas mais complexas, tratadas por Barros (2002) como Programas Narrativos, e que Greimas chama de estruturas modais ([1983] 2014, p. 83), dividindo-as em enunciados de 
performance (fazer-ser) e competência (ser-fazer) e, a partir do cruzamento dessas, criar-se outras modalidades como a veridicção (ser-ser) e factividade (fazer-fazer).

Eis a abertura necessária para que Greimas proponha, então, uma espécie de modalidades das modalidades, chamada por ele de sobremodalizações, alocadas na instância da competência, ou seja, enunciados de estado que transformam o fazer do sujeito, dividindo-se em: modalidades virtualizantes (as que criam uma relação juntiva com o objeto modal) e atualizantes (que põe sujeito e objeto modal em processo).

Fato é que o Dor "investidor" depende diretamente do fazer performático do sujeito trabalhador. Ou seja, na cadeia de enunciados complexos e anexos da trama narrativa de Adam Smith, o "investidor" Destinador é o actante mais próximo do sujeito "trabalhador", que por sua vez transforma em estado conjuntivo a relação entre o objeto de valor "riqueza" e o outro sujeito "nação":

Poder-se-ia talvez pensar que os lucros do patrimônio não passam de uma designação diferente para os salários de um tipo especial de trabalho, isto é, o trabalho de inspecionar e dirigir a empresa. No entanto, trata-se de duas coisas bem diferentes; [...] Também já não se pode dizer que a quantidade de trabalho normalmente empregada para adquirir ou produzir uma mercadoria seja a única circunstância a determinar a quantidade que ele [investidor] normalmente pode comprar, comandar ou pela qual pode ser trocada. É evidente que uma quantidade adicional é devida pelos lucros do capital, pois este adiantou os salários e forneceu os materiais para o trabalho dos operários. (SMITH [1776] 1996, p. 102-103)

O "investidor" emprega seu capital sobre o "trabalhador", sobremodalizando-o. Assim, se se considera que a etapa de manipulação é o fazer do Dor, e que todo fazer pressupõe uma competência, ou seja, uma modalidade atualizada (Barros, 2002, p. 50), então o investidor é aquele que detém um poder fazer-dever, aquele que tem condições de criar um senso deôntico em outro sujeito, manifestado no texto como "poder comandar" 39. O sujeito "trabalhador", por sua vez, é sobremodalizado por um dever poder-fazer, ou seja, deve ser capaz de executar suas tarefas, para finalmente ambos entrarem em conjunção, cada qual com seu objeto de valor, como apresentados anteriormente, os "lucros" e os "salários".

Greimas trata dessa tal instância pressuposta da competência no capítulo "Para uma teoria das modalidades", dizendo:

39 Do original, "command". 
Se levarmos em conta apenas a competência pragmática e, além disso, a considerarmos uma instância potencial pressuposta pelo ato, poderemos propor sua articulação em dois níveis de existência, sendo que: (a) cada nível será caracterizado por um modo de existência semiótico particular e (b) os níveis manterão entre si a relação de pressuposição orientada a partir da performance (que pressupõe a competência). (GREIMAS, [1983] 2014, p. 92)

Acerca desses dois níveis, o linguista se refere à competência e à performance, e, no percurso de uma à outra, há uma gradação de enunciados entre as extremidades do discurso virtualizado e o realizado (FONTANILLE, 2015, p. 173, grifo nosso).

Uma vez assinados os contratos reais do "investidor", e aceitos os contratos narrativos pelo fazer interpretativo do $\mathrm{D}^{\text {ario }}$ o $\mathrm{D}^{\text {or }}$ estende sua manipulação dos domínios do fazer-fazer cognitivo aos do fazer-fazer pragmático. A fim de manter em ordem a jornada do sujeito "trabalhador", é preciso que este seja constantemente observado:

[...] acontece, porém, que nessas manufaturas menores, destinadas a suprir as pequenas necessidades de um número pequeno de pessoas, o número total de trabalhadores é necessariamente menor, e os trabalhadores empregados em cada setor de trabalho muitas vezes podem ser reunidos no mesmo local de trabalho e colocados imediatamente sob a perspectiva do espectador. (SMITH, [1776] 1996, p. 65)

Assim, seria possível propor um percurso manipulativo contínuo de tal Destinador, dividido em dois momentos, por ora:

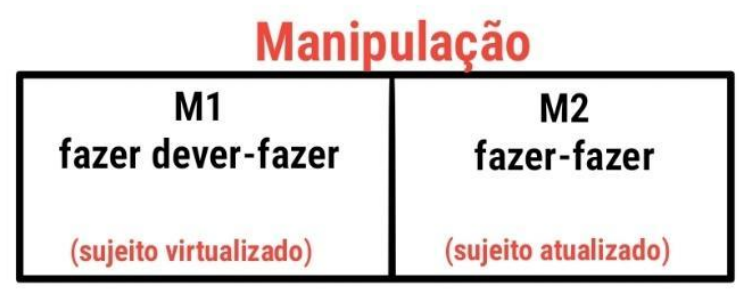

Vê-se uma espécie de manutenção do fazer do sujeito sob a perspectiva do "investidor" para que aquele cumpra seu papel actancial na esteira da produção de seu trabalho, ou seja, o fazer pragmático do produto, obtido através da performance, seja um parafuso, um móvel ou a colheita de uma safra de frutas. Contudo, há ainda outro actante que comparece diretamente no enunciado final de estado do percurso do sujeito e na manipulação do $\mathrm{D}^{\text {or }}$-investidor, acentuando ainda mais seu poder sobre o $\mathrm{D}^{\text {ario }}$-sujeito: o objeto de valor salário. 


\subsubsection{A sanção pragmática: salário}

Ainda acerca da teoria das modalidades que fazem parte das práticas do Destinador, resta aquela que trata do ser agindo sobre os seres, ou seja, para trocar em termos semióticos, um enunciado de estado que possua um sujeito $S^{1}$ que pode modificar totalmente outro enunciado de estado produzido por um sujeito $S^{2}$ (GREIMAS, [1983] 2014, p. 84). Barros, de maneira bastante didática, elucida essa modalidade do ser-ser da seguinte maneira:

O destinador julga o sujeito pela verificação de suas ações e dos valores com que se relaciona. Essa operação cognitiva de leitura, ou melhor, de reconhecimento do sujeito, consiste na interpretação veridictória dos estados resultantes do fazer do sujeito. Os estados são, dessa forma, definidos como verdadeiros (que parecem e são) ou falsos (que não parecem e não são) ou mentirosos (que parecem, mas não são) ou secretos (que não parecem, mas são), e o destinador neles acredita ou deles duvida. (BARROS, 2002, p. 35)

De igual forma, o $\mathrm{D}^{\text {or }}$-investidor (S1) sanciona cognitivamente e pragmaticamente o fazer do sujeito "trabalhador" (S2). Constituiu-se a articulação desse quadrado não somente para o propósito da análise em si, como também uma espécie de modelo geral para exemplificar as relações de trabalho em geral, daí ao uso de alguns exemplos figurativos descontextualizados da obra. Assim, no tocante à sanção cognitiva, esta ocorre através da Aprovação (ser + parecer), ou seja, a obtenção completa do "objeto" pelo sujeito (parabéns! Os 100 pregos foram produzidos em uma hora!), enquanto que total ineficiência (não ser + não parecer) na etapa de conjunção significaria, em termos categoriais semânticos, a Reprovação (Incapaz! Você produziu apenas 2 pregos em uma hora!). Para ilustrar melhor, optou-se por lançar mão do mesmo quadrado veridictório de Greimas: 


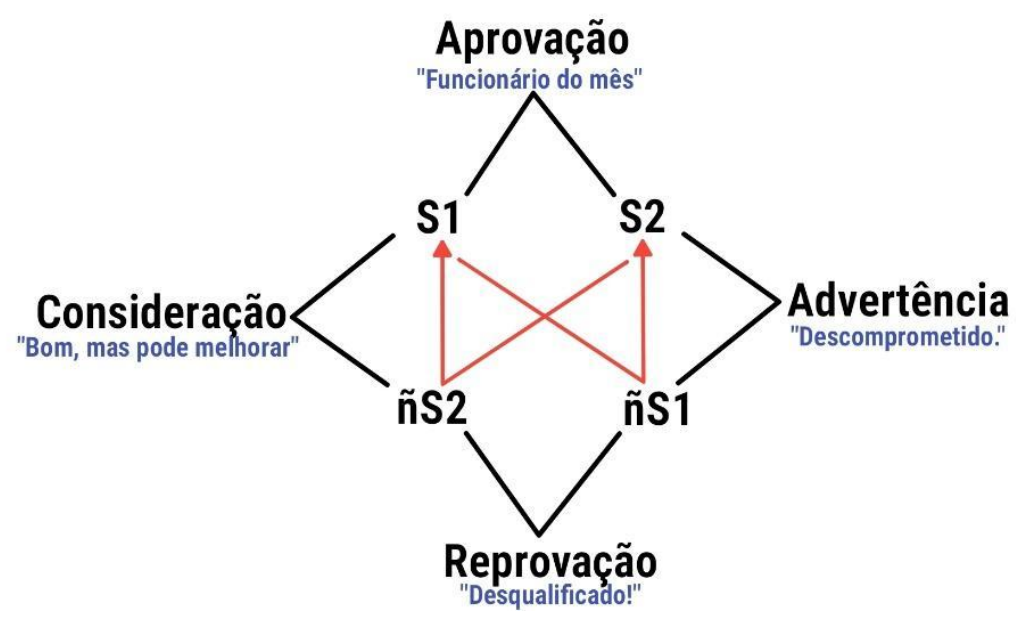

Finalmente, para concretizar todo o trajeto do Destinador-julgador, é necessário expor ainda a fase da sanção pragmática, em que se compensa ou penaliza o fazer do sujeito através de premiações ou castigos. Em relação ao corpus analisado, o pagamento do salário não somente trata dessa recompensa em relação ao sujeito "trabalhador", como diz respeito também a um instrumento de outorga de poder (comanda) utilizado pelo Destinador. Para tal, o enunciador de Adam Smith descreve a relação de valor do salário frente a Destinador e sujeito como instável e arbitrário:

Contudo, embora quantidades iguais de trabalho sempre tenham valor igual para o trabalhador, para a pessoa que as emprega, essas quantidades de trabalho apresentam valor ora maior, ora menor, o empregador compra o trabalho do operário ora por uma quantidade maior de bens, ora por uma quantidade menor. (SMITH, [1776] 1996, p. 90)

Portanto, para finalizar o arco da trajetória de manipulação do $\mathrm{D}^{\text {or }}$-investidor, uma vez que o sujeito fora virtualizado e atualizado, finalmente, o referido actante o sanciona num terceiro momento (M3), transformando seu estatuto de sujeito como realizado:

\footnotetext{
${ }^{40}$ Ao confrontar ambos os trechos, há um pequeno detalhe na tradução, talvez irrelevante, mas que por fim decidiu-se dar nota: Enquanto o verbo "empregar", no original, transita em direção ao objeto "him", que por sua vez, anaforiza "labourer", na edição brasileira o pronome oblíquo "as" se refere a "quantidades iguais" o que não coopera para o sentido do pensamento apresentado por A. Smith no original: "But though equal quantities of labour are always of equal value to the labourer, yet to the person who employs him they appear sometimes to be of greater and sometimes of smaller value". (2007, p. 30)
} 


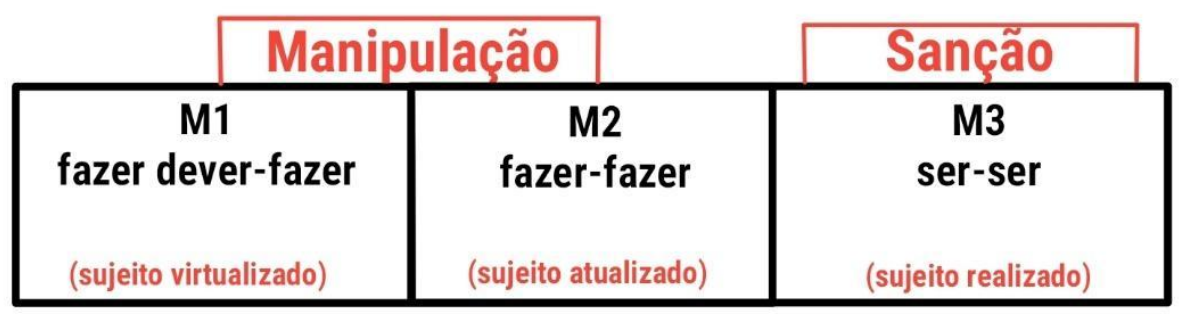

Se a sanção do Destinador estiver operando no eixo dos contrários (S1-S2) sobre o fazer do sujeito, é reconhecida como verdadeira e o objeto salário lhe é atribuído; caso a

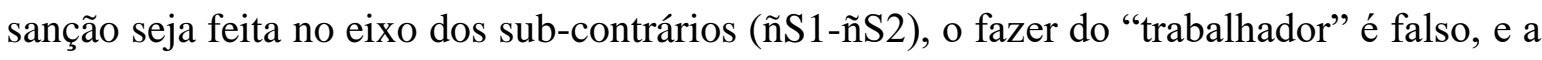
pena é imputada ao referido actante, no caso, figurativizada pelo não pagamento do salário, ou, em alguns casos, a depender dos contratos que sintagmatizem Dor e $\mathrm{D}^{\text {rio }}$-sujeito, a demissão.

Assim, ao término de sua jornada de trabalho, seja ela semanal ou mensal, será possível reconhecer o "trabalhador", para o bem da nação, e da produção - assim se espera - bem sucedido e cumpridor do seu "dever".

\subsubsection{O investidor, o senhor da terra e os objetos de valor}

Apesar de "Arrendar terras" e "comandar trabalho" possuírem diferenças em suas manifestações lexicais, em nada auxiliaria apenas confrontá-los para que se postulassem as diferenças entre actantes no nível narrativo. Como visto anteriormente, tais sobremodalizações trabalham para o estabelecimento de um estado de enunciados que transformam outros, costurando-os no nível narrativo e, por conta dessa proposta greimasiana sobre as modalidades, torna-se possível compreender a tênue diferença entre "investidor" e "senhor da terra", ainda que executando papeis actanciais iguais e em percursos - ou seriam esquemas narrativos? - distintos.

Enquanto "comandar um trabalhador" para se obter o "lucro" significa, na instância das modalizações, como sujeito atualizado por uma competência, um poder fazer-dever, "arrendar a terra" trata-se de poder fazer-poder. Para se demarcar ainda mais a diferença de suas performances enquanto sujeitos que fazem fazer, é importante também se observar os “objetos de valor" (Ov), ou seja, olhando para esses actantes objetais, é possível entender melhor as formas de agir desses Destinadores. No livro I, Capítulo XI, se diz o seguinte, sobre tais "objetos": 
Cumpre observar, portanto, que a renda entra na composição do preço das mercadorias de uma forma diferente dos salários e do lucro. Salários e lucros altos ou baixos são a causa do preço alto ou baixo das mercadorias, ao passo que a renda da locação da terra, alta ou baixa, constitui o efeito dos preços altos ou baixos das mercadorias. Se o preço de uma mercadoria é alto ou baixo, é porque se precisa pagar salários e lucro altos ou baixos para comercializá-la. (SMITH, [1776] 1996 p. 187)

O ser do objeto "lucro" - não se levando em consideração para o momento, "salários" - afeta diretamente os preços das mercadorias, diferentemente da "renda da terra", que é afetada. Por conta disso, a sobremodalização do sujeito "investidor" sobre o "trabalhador" é muito mais da ordem da "intimidação", enquanto que a do "senhor da terra" é a da "tentação".

Uma intermissão razoável precisa ser feita por conta de um apontamento acerca da confiança do "investidor": na etapa da manipulação em si, o D or opera um fazer persuasivo sobre o fazer interpretativo do $\mathrm{D}^{\text {ario }}$ no estabelecimento de seu contrato, um momento em que, mais uma vez, as modalidades reaparecem como conversoras de enunciados, desta feita, um fazer-crer do $\mathrm{D}^{\text {or }}$ sobre o crer do $\mathrm{D}^{\text {ario. }}$.

Essa modalidade do fazer epistêmico, a qual se estabelece no interior do contrato enunciativo entre enunciador e enunciatário (COURTÉS \& GREIMAS, [1986] 2008, p. 172), ocorre entre investidor e trabalhador na obra de Adam Smith, e, de maneira peculiar, se dá numa dupla transitividade entre os sujeitos "investidor" (proprietário) e "trabalhador" (funcionários):

Embora ao empregar esses funcionários geralmente se considere, até certo ponto, não somente seu trabalho e sua habilidade, mas também a confiança que nele se deposita, esses fatores nunca têm uma proporção regular cuja administração eles supervisionam; e o proprietário desse capital, embora fique assim quase isento desse trabalho, continua a esperar que seus lucros mantenham uma proporção regular com seu capital. (SMITH, [1776] 1996, p. 103, grifo nosso).

Nesse intrincado e complexo jogo persuasivo, parece que não se trata apenas de um sujeito de estado inerte aos conteúdos que recebe, afetado somente, mas que também afeta o outro, abrindo precedente para uma espécie de "microeconomia narrativa da manipulação 
semiótica", em que sujeitos comunicam objetos uns aos outros e esperam, em enunciados posteriores, um estado juntivo com lucros ou juros em relação à busca de seus objetos ${ }^{41}$.

Para não incorrer em análises paralelas das afetividades, que não renderiam frutos se fossem examinadas, tanto pela tamanha complexidade desse tipo de análise, quanto pelo pouco preparo das lentes deste trabalho, necessário é prosseguir.

\subsubsection{A função do trabalhador entre nação e bens}

O sujeito "trabalhador" possui um papel actancial peculiar na narrativa smithiana por causa de sua participação efetiva e direta no programa narrativo de base proposto pela análise. Ainda que o percurso dos sujeitos "investidor" e "senhor da terra" seja, também, fundamental para a efetivação da conjunção entre o sujeito "nação" e o objeto de valor "bens", nenhum deles entra em relação tão direta com o programa principal da narrativa da obra quanto o sujeito "trabalhador".

Como já apresentado, o sujeito figurativizado como "nação" recobre um amplo espectro de outros atores em nível discursivo como trabalhador, investidor, senhor de terra, os quais, consequentemente, são articulados num nível mais profundo por diferentes actantes, configurando-se um claro sincretismo actancial. De igual forma, o termo manifestado "bens" abrange outros objetos actanciais de interesse, também figurativizados no discurso como "bens de consumo", "salários", "renda", etc.

Além disso, o enunciador inaugura o seu pensamento num capítulo intitulado "Introdução e Plano da Obra", dizendo que, para que o sujeito nação entre em conjunção com seu objeto, são necessárias, mais especificamente, duas condições: 1. da produção através das competências do trabalhador, dentre elas, sua habilidade, bom senso e destreza e 2. que a proporção entre número dos que executam trabalho útil e aqueles que não realizam trabalho algum seja sempre maior em relação aos primeiros. Essas duas grandes premissas estão acima de quaisquer condições geográficas, climáticas e territoriais:

Essa proporção deve em cada nação ser regulada ou determinada por duas circunstâncias diferentes; primeiro, pela habilidade, destreza e bom senso com os quais seu trabalho for geralmente executado; em segundo lugar,

\footnotetext{
41 A semiótica das paixões trata, assim, das modalizações não mais sobre o fazer do ser, mas sobre o ser durante a etapa de comunicação dos objetos em questão, mais precisamente, na manipulação gerada de um sujeito para com o outro (BARROS, 2002, p. 60).
} 
pela proporção entre o número dos que executam trabalho útil e o dos que não executam tal trabalho. Qualquer que seja o solo, o clima ou a extensão do território de uma determinada nação, a abundância ou escassez do montante anual de bens de que disporá, nessa situação específica, dependerá necessariamente das duas circunstâncias que acabamos de mencionar. (SMITH, [1756] 1996, p. 50).

Em ambas, assumidas doravante como enunciados A e Z, é possível visualizar a intensidade e a extensidade do fazer do sujeito "trabalhador", respectivamente, subjacente ao enunciado elementar principal Nação $\cap$ Bens:

\section{Enunciado A S1 $\cap$ Ovm Enunciado Z s1 $\cup$ ovm \\ logo $\mathrm{A}$ deve ser $>\mathrm{Z}$}

\section{S1: trabalhador Ovm: saber/poder fazer, saber saber}

O primeiro e mais importante trata de uma espécie de "tônus da competência modalizada", um actante que possui "habilidade, destreza e bom senso", ou seja, um sujeito competencializado e atualizado pelos valores modais de um saber-fazer, um poder-fazer e um saber-saber. Veja-se isso mais detalhadamente:

1. O objeto de valor modal nada mais é que uma característica em estado predicativo juntivo ao sujeito que, por conta de seu valor narrativamente modalizador, atualiza-o de maneira a tornar um enunciado descritivo, de estado, ser, um enunciado de transformação sobre outro enunciado, fazer. Segundo Greimas:

\footnotetext{
Ora, em nosso caso, o procedimento de denominação consiste no que se pode chamar nominalização, isto é, na conversão de uma formulação verbal em formulação nominal que transforme o predicado modal em um valor modal. (GREIMAS, [1983] 2014, pg. 90)
}

Sendo assim, o sujeito smithiano "trabalhador" precisa estar modalizado por um saber-fazer, de caráter endotáxico, intrínseco ao sujeito, manifestando-se em discursos vários como "saber construir uma parede", "saber bater o martelo sobre um prego", e coisas do tipo.

2. Já sobre o outro tipo de modalidade, do poder-fazer, também endotáxica, o autor trata da capacidade pragmática em si, do quão destro e eficiente é aquele sujeito em, 
seguindo os exemplos, "levantar uma parede resistente, de linhas retas" ou "cravar determinada quantidade de pregos numa superfície em um determinado período”. Note-se, entretanto, que, para se alcançar esse nível de destreza, Smith vai falar especificamente que é a Divisão do Trabalho (DIT) responsável por essa majoração da competencialização do sujeito. Tratar-se-á mais adiante dela.

3. Finalmente, o "bom senso", o saber-saber, nada mais é do que a noção e o domínio crítico do próprio conhecimento e de suas fronteiras ${ }^{42}$. Assim, o sujeito não só tem que saber, como também precisa estar conjunto com uma categoria do meta-saber.

Sobre essas duas últimas modalizações, do poder-fazer, e do saber-saber, circunscrevem-se uma complexa rede de fazeres narrativos e uma advertência em nível discursivo, que, como bem se sabe, não condiz com o momento desta análise, mas que, para fins didáticos, ainda assim se opta por mostrá-la logo a seguir.

\subsubsection{A Divisão do Trabalho e o Poder-Fazer do Actante Coletivo: o trabalho como fim em si}

Como apresentado anteriormente, é necessário que o sujeito "trabalhador" tenha, além de sua habilidade modalizante do saber-fazer, uma competência da estrutura de um poder-fazer: textualizada como "destreza" é, na verdade, uma potencialização das modalidades atualizadas no sujeito:

Em primeiro lugar, vejamos como o aprimoramento da destreza do
operário necessariamente aumenta a quantidade de serviço que ele pode
realizar; a divisão do trabalho, reduzindo a atividade de cada pessoa a
alguma operação simples [...] Em segundo lugar, a vantagem que se
aufere economizando o tempo que geralmente se perderia no passar de um
tipo de trabalho para o outro é muito maior [...] Geralmente, uma pessoa
se desconcerta um pouco ao passar de um tipo de trabalho para outro. [...]
Em terceiro - e último lugar - precisamos todos tomar consciência de
quanto o trabalho é facilitado e abreviado pela utilização de máquinas
adequadas. (SMITH, [1776] 1996, p. 68)

${ }^{42}$ Segundo o dicionário Aulete, Bom senso: 1 Filos. Em questões correntes e habituais, aptidão intuitiva de discernir entre o verdadeiro e o falso, o certo e o errado, o bom e o mau etc. [Cf. senso comum.]; 2 Uso adequado do raciocínio e da razão na avaliação de situações e tomada de decisões; 3 Capacidade de avaliar e de resolver problemas e situações de acordo com o senso comum. 
Será a Divisão do Trabalho (DIT), portanto, um programa narrativo complexo, modalizador de outro enunciado, constituído de outros programas de uso. A esse PN complexo delega-se o $\mathrm{D}^{\text {or }}$-investidor como responsável pela execução da transformação (F).

Como apresentado anteriormente, essa nova organização do trabalho nada mais é do que uma consequência da faculdade de troca, pois a permuta de objetos só é praticável haja vista a especialização natural do ser humano, segundo Smith. Ao cabo, a DIT otimiza a produção nas fábricas e nas pequenas manufaturas, dotando o sujeito de um dever poderfazer - como já exposto anteriormente, pelo fazer-fazer ("comando") do $\mathrm{D}^{\text {or }}$-investidor - o que explica o direcionamento para um único tipo de "operação simples".

O enunciador encaminha seu discurso para apresentar o quanto o "trabalho" é digno de atenção para os actantes envolvidos no processo de sintagmatização de seus percursos e programas. A fim de se visualizar melhor estes sintagmas elementares narrativos (BARROS, 2003, p.31), nota-se que o termo "produção", manifestando o valor do labor, não à toa, serve como tomada de direção para todo o esquema narrativo do que o enunciador vai chamar de "divisão do trabalho".

Essa eficiência na produção de bens é a competencialização que nada mais é que as condições requeridas para o seu exercício (BERTRAND, 2003, p. 297), da performance dos sujeitos envolvidos, as quais se otimizam por conta da já citada fragmentação do processo de manufatura dos bens e da especificação das funções pertinentes a cada trabalhador, como tal nas primeiras linhas do capítulo I de A Riqueza das Nações.

Para isso, o autor expõe as possíveis ocupações requeridas para a confecção de um alfinete e alega que, enquanto um único trabalhador teria fabricado não mais que duas dezenas por dia, uma fábrica que dividisse a confecção de um único alfinete em tantos outros tipos de ofícios diferentes, poderia alcançar a margem de milhares de peças por dia:

Entretanto, da forma como essa atividade é hoje executada, não somente o trabalho todo constitui uma indústria específica, mas ele está dividido em uma série de setores, dos quais, por sua vez, a maior parte também constitui provavelmente um ofício especial [...] Assim, a importante atividade de fabricar um alfinete está dividida em aproximadamente 18 operações distintas, as quais, em algumas manufaturas são executadas por pessoas diferentes, ao passo que, em outras, o mesmo operário às vezes executa 2 ou 3 delas. (SMITH, [1776] 1996, p. 66).

O sujeito "trabalhador" passa a ser sintagmatizado não mais num único programa narrativo de base constituído pelo percurso de um único sujeito, mas sim em uma intrincada 
rede de programas narrativos de uso, em que se esquematizam uma série de enunciados, multiplicando o fazer em fazeres, coletivizando o sujeito em sujeitos e fragmentando o objeto em relação direta ao número dos actantes, exemplificado da seguinte maneira:

DIT

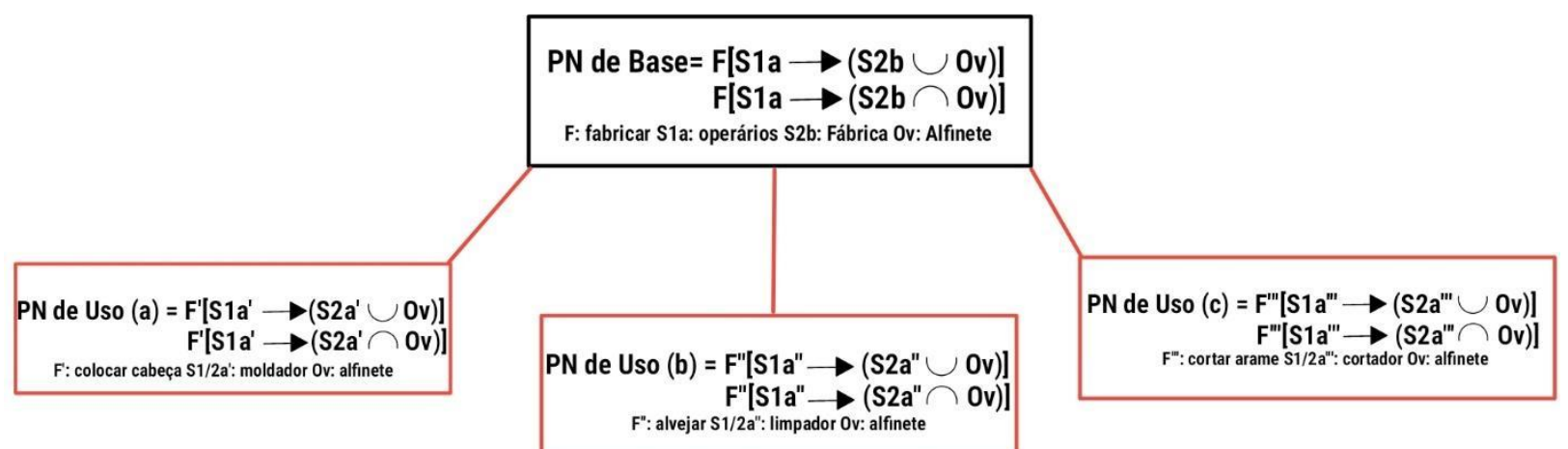

Toma-se o cuidado de distinguir o "cortador" do "limpador", por exemplo, para não se confundir uma coletividade subjetal com o conceito de sincretismo já abordado anteriormente. A fim de se tornar mais claro ainda o esquema proposto, Greimas, em sua Semiótica e Ciências Sociais, ao analisar ${ }^{43}$ as leis que governavam os grupos de sociedades comerciais, postula um sofisticado conceito sobre o sujeito coletivo ${ }^{44}$, em que assume para isso uma coletividade actancial de dois tipos: sintagmáticos e paradigmáticos. Este se trata do tipo de actancialidade em que os sujeitos não são integrados em algum tipo de percurso em comum, e que, por isso mesmo, dependem de uma instância superior que os coloquem numa relação sistêmica, e não processual ${ }^{45}$ (ex.: a secretária de uma escola, seus inspetores e cozinheiros.); de outra maneira, os actantes sintagmáticos, ainda que atorializados por diferentes figuras, encadeiam-se em diferentes momentos dentro de um mesmo grande programa, orientados para um único grande objeto (ex: os professores de diferentes disciplinas em uma escola). Greimas diz:

\footnotetext{
${ }^{43}$ Com a colaboração de Eric Landowski.

44 "Isso equivale a dizer que a possibilidade de construção de actantes coletivos depende de nossa faculdade geral de imaginar diferentes modos de existência de "seres quantitativos", de conceber, no continuum do mundo, diferentes recortes em unidades e totalidades descontínuas, sendo justamente unidade e totalidade categoriais universais que tornam possível semelhante recorte.” (GREIMAS, [1975] 1981, p. 84).

${ }^{45}$ Greimas ([1975] 1981, p. 85) atesta também, sobre as características do actante coletivo paradigmático, que ele "opera à base de critérios-determinações que os atores possuem em comum”. Não fica tão clara a compreensão, visto que, num primeiro olhar, atores como, por exemplo, "separador de parafuso", "colocador de parafuso" e "apertador de parafuso" possuem sobredeterminações idênticas, mas que de maneira alguma estão separados em processo, compondo a mesma esteira objetal.
} 
Se definirmos o actante unicamente pelo conjunto de suas funções, isto é, pelo programa virtual que ele é capaz de atualizar, percebemos, por exemplo, que a Renault (ou qualquer outra empresa de construção de automóveis) pode ser considerada como um actante sintagmático na medida em que, dentro de um único programa de construção, diferentes atores (engenheiros, contramestres, operários especializados, etc.) substituem-se progressivamente uns aos outros para, executando um programa único, produzir o auto-móvel. (GREIMAS, [1975]1981, p. 85).

Com o intuito de dar conta deste "programa de construção", dar-se-á um sujeito para cada PN de uso, todos estes de caráter factivo ${ }^{46}$, chamados especificamente de PNs de uso, sequenciais e não necessariamente em níveis hierárquicos performáticos de agravamento ou atenuação dos tipos de atividade, ou seja, há uma isomorfia entre os actantes e os objetos em seus diferentes enunciados. Todos esses programas servem para se chegar àquele PN de base maior que, por fim, visa à mudança de enunciado de disjunção entre sujeito (S) e objeto $(\mathrm{O})$ para sua conjunção.

Ao cabo desta etapa da análise, é possível, portanto, vislumbrar um sincretismo actancial $^{47}$ em "Fábrica", no qual atores distintos realizam diferentes performances, ainda que investidos na mesma categoria actancial da sintaxe narrativa do trabalho: um indivíduo se encarrega de separar os arames, o outro do corte, o seguinte do polimento, e assim por diante.

O último elemento citado por Smith, a instrumentação emprestada aos trabalhadores, revestida discursivamente como "máquinas", nada mais é que uma competência modal inserida no sujeito da ordem do poder-fazer, virtualizando-o de forma que possa produzir seu objeto, seja ela a vapor, ou uma máquina de tear menos complexa.

Assim, a DIT funciona como um complexo enunciado modalizador, útil ao fazer manipulativo do "investidor", Destinador direto da massa de trabalhadores de uma fábrica, servindo única e exclusivamente para uma intensificação da performance dos seus sujeitos, visando o máximo de produção de seus objetos.

\footnotetext{
${ }^{46}$ Segundo o Dicionário de Semiótica (GREIMAS \& COURTÉS, [1986] 2008, p.388-389) é importante ressaltar que uma taxonomia dos tipos de PN é necessária para, por exemplo, separar os tipos de trajetórias dos sujeitos segundo aquilo que se constrói no nível discursivo, se se trata de um PN de natureza modal ou descritivo e, dentre estes, se pragmático ou cognitivo. Quando Smith utiliza a isotopia tecnológica, valendo-se de figuras como o da indústria e da fábrica para demonstrar a manufatura seriada dos trabalhadores numa esteira de produção de um dado objeto concreto, é fatal a conclusão de um PN descritivo de caráter pragmático.
}

${ }^{47}$ Tatit, 2001, 51. 


\subsubsection{A riqueza do trabalho}

De modo a encaminhar a pesquisa para outra etapa, retoma-se o trecho inicial e emblemático da introdução da obra, "O trabalho anual de cada nação constitui o fundo que originalmente lhe fornece todos os bens necessários e os confortos materiais que consome anualmente." (SMITH, [1776] 1996, p. 59), ou seja, esse fundo ao qual se refere o enunciador $\mathrm{D}^{\text {or }}$-julgador é mais do que a própria nominalização do ato, mas o ato de per-si.

Eis, portanto, a modalidade central de todo o construto narrativo por debaixo do discurso de ARN, e que se demonstra nesta etapa de análise: o fazer do sujeito trabalhador, semiotraduzido na manifestação do texto como trabalho, produzido pela performance dos mais variados sujeitos com suas várias categorias e profissões discursivizadas de um país do ajudante mais simples de uma casa de curtume ao operário da forja mais sofisticada - é, em primeira instância, a mais importante de todas as modalidades constitutivas dos demais sujeitos da narrativa smithiana.

Em última instância e hipótese de análise, o mesmo trabalho é, além da figurativização da competência daquele sujeito em nível discursivo, senão o próprio objeto de valor do sujeito nação. Assim, o algoritmo narrativo é aquele que uma nação trabalha para consumir bens e que também consome bens para trabalhar. Propõe-se assim uma provável distinção mais fina, de maneira a postular uma intencionalidade semiótica percorrida e autônoma como a própria noção de texto, apontando um sentido "maior" nessa relação actancial. Assim fala Barros (2002, p. 44), sobre a intencionalidade:

Intencionalidade diferencia-se de intenção. Uma narrativa determinada pela intenção restringiria sua produção e desenvolvimento a atos voluntários e conscientes [...] A intencionalidade, distinta da intenção, não se identifica, para Greimas, nem com a motivação, nem com a finalidade, mas as engloba. Dessa forma, é possível conceber as transformações narrativas como uma tensão entre dois modos de existência, a virtualidade e a realização, como uma relação orientada, transitiva, entre sujeito e objeto.

Ou seja, o sentido do movimento ocorrido na performance do trabalho na relação entre sujeito e objeto, corresponderia a essa força sintáxica responsável pelas transformações e estados que se produzem pelo e para o trabalho, confirmando-se uma 
espécie de circularidade ${ }^{48}$ estabelecida na lógica liberal de Adam Smith, em que a produção de um bem, de uma nova tecnologia, ou um novo serviço, não deve ser um fim em si, mas o próprio meio para manter a "roda" girando, e se aperfeiçoando nos variados objetos de valor oferecidos aos sujeitos, em constante renovação, discursivizados na superfície como as "necessidades" do homem em seu tempo. Daí que a tensão entre a virtualização (do que pode vir a ser) e a realização (do que é) é extremamente necessária para que nunca se "resolva" definitivamente:

\section{$S \cup$ Ova $\quad x \quad S \cup$ Ovb \\ S: nação Ova: bens Ovb: trabalho}

Por último, ainda resta a tarefa aberta sobre o "bom senso", orientado por um sabersaber, e que carece de um breve tratamento por demonstrar uma aparente contradição, em nível discursivo, mas que se opta por elucidar logo adiante.

\subsubsection{A DIT e o bom senso do trabalhador}

Smith inicia suas primeiras ideias com o reforço da importância da Divisão do trabalho e de sua característica pujante de potencialização da produção:

O maior aprimoramento das forças produtivas do trabalho, e a maior parte da habilidade, destreza e bom senso com os quais o trabalho é em toda parte dirigido ou executado, parecem ter sido resultados da divisão do trabalho. (SMITH, [1776] 1996, p. 65)

Contudo, a DIT e sua aparente capacidade de intensificar quantitativamente a produção de bens são, a um só tempo, alvo de críticas. Marx em seu basilar O Capital, no capítulo 12 da Seção IV, "Divisão do Trabalho e Manufatura”, apresenta outro panorama sobre o próprio conceito de Smith e da concentração dos meios de produção:

\footnotetext{
48 A essa trama se dá o nome de "processo de causalidade circular cumulativa", já aludida na introdução geral da obra e citada por Sandroni em sua apresentação na referida obra, a qual foi criada por Gunnar Myrdal, economista sueco, autor da consagrada obra The Political Element in the Development of Economic Theory, 1953.
} 
Não cabe aqui prosseguirmos com a demonstração de como essa divisão se apossa não apenas da esfera econômica, mas de todas as outras esferas da sociedade, firmando por toda parte as bases para aquele avanço da especialização, das especialidades, de um parcelamento do homem que já levara A. Ferguson, professor de A. Smith, a exclamar: 'Estamos criando uma nação de hilotas, e já não há homens livres entre nós'. (MARX, 1989, p.532)

Além disso, há inúmera literatura e discussões nas áreas acadêmicas da História e da própria Economia sobre o empobrecimento das condições de trabalho às quais os operários eram submetidos, principalmente no final do século XVIII a meados do XIX.

Para o presente momento da análise, levanta-se um "pequeno" problema o qual subjaz à teoria smithiana e que, por vezes, desponta nos escritos dessas mesmas críticas. Graças à ciência do sentido proposta pelos trabalhos de Greimas e, logicamente, de tantos outros sucessores, parece possível trazer à tona uma aparente contradição nas bases da teoria proposta pelo economista inglês: o bom senso do trabalhador frente ao seu embrutecimento pelos modos de produção da DIT.

Na contramão, o bom senso do sujeito nada mais é que o nível maduro de discernimento do próprio trabalhador, com fins de resoluções e tomadas de decisões assertivas em seus fazeres. Em termos greimasianos, é o saber-saber dos sujeitos frente aos inúmeros enunciados que lhe aparecem e que a eles deve prescrever seus atos e estados. Eis a contradição discursiva da DIT, em que um fazer saber-saber, na verdade, nada mais é do que uma sobremodalização descompetencializante de um fazer não saber-saber.

A contradição somente não se concretiza mais devido ao próprio enunciador (ra)retificar a importância e o cuidado que se deve ter com esse modelo de linha de produção proposto:

Com o avanço da divisão do trabalho, a ocupação da maior parte daqueles que vivem do trabalho, isto é, da maioria da população, acaba restringindo-se a algumas operações extremamente simples, muitas vezes a uma ou duas. [...] Ele perde naturalmente o hábito de fazer isso, tornando-se geralmente tão embotado e ignorante quanto o possa ser uma criatura humana. $\mathrm{O}$ entorpecimento de sua mente o torna não somente incapaz de saborear ou ter alguma participação em toda conversação racional, mas também de conceber algum sentimento generoso, nobre ou terno, e, consequentemente, de formar algum julgamento justo até mesmo acerca de muitas das obrigações normais da vida privada. (SMITH, [1776] 1996, p. 244) ${ }^{49}$

${ }^{49}$ Livro V, artigo III: os gastos com as instituições destinadas à instrução das pessoas de todas as idades. 
Assim, a fim de se demonstrar um dado altamente stricto sensu da análise, aquilo que o enunciador manifesta discursivamente em relação à DIT se constrói em nível profundo, no percurso gerador de sentido, da seguinte forma:

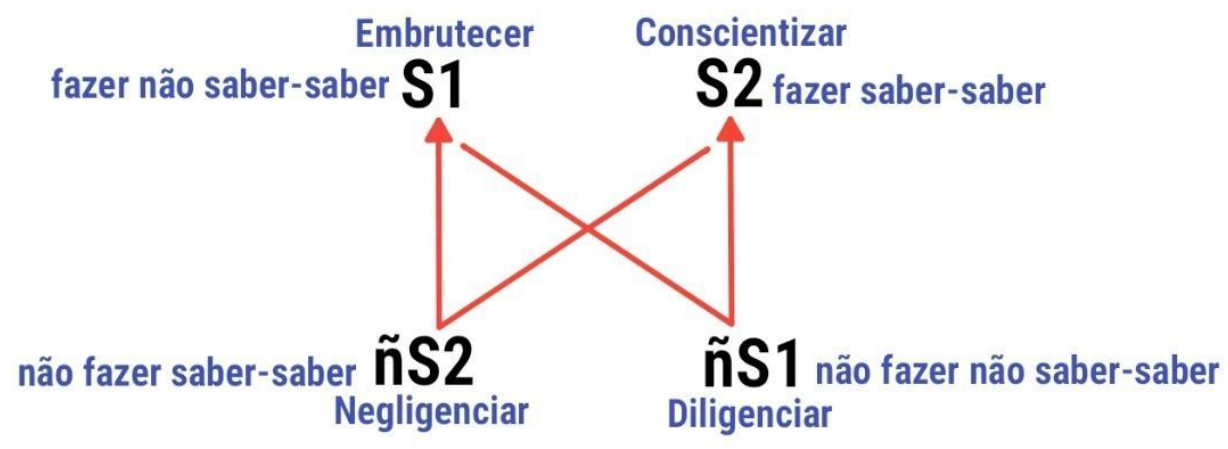

É possível ver, portanto, que o percurso ascendente do sentido no tocante à DIT se inicia, no Livro I, como algo poderoso e necessário para o enriquecimento de qualquer nação, mas que, em desmedida - não sendo claras quais medidas exatas seriam - e, pior, sem a educação crítica de um povo, tal modo de produção se torna contraproducente, segundo o próprio autor.

\section{O antissujeito liberal: mercantilismo}

Como já apresentado no capítulo sobre o nível fundamental da análise, o mercantilismo é encarado em A Riqueza das Nações como um termo categorial semântico disfórico por causa de sua carga de valores opostos em relação a outro componente do esquema lógico do quadrado, no caso, o liberalismo, com suas políticas ultraprotecionistas e maneiras de se administrar e produzir riqueza através de colonizações e limitação de mercado. Assim estabelecido, de certo há uma conversão entre níveis, e não seria estranho encontrar o seu correspondente actancial, traduzindo aquela força operante opositiva ao liberalismo tradicional da obra.

Em nível narrativo, ainda que disforizante, essa tal força é também subsumida por um sujeito que igualmente sente e interage diante de seu objeto e em direção a ele produz 
seus enunciados diversos. Uma vez examinado e apresentado o sujeito nação, e seu objeto riqueza, constituído pela coletividade de outros agentes, sobretudo do trabalhador comum, resta verificar qual seria a categoria diferencial que separa esses sujeitos desse outro que lhes faz frente.

Apesar de o próprio Greimas tecer considerações sobre a aplicabilidade do termo antissujeito $^{50}$, e que nem mesmo sua entrada figura no próprio Dicionário de Semiótica (GREIMAS \& COURTÉS, [1986] 2008), seu uso possui vasta ocorrência e recorrência, principalmente nas análises semióticas de cunho greimasiano, consideradas como semiótica standard.

Seguindo pelos mesmos caminhos, este trabalho também se permite propor um papel antissubjetal, o qual desponta com certa frequência e intensidade, sobretudo pela amostragem levantada na análise do corpus. Por se situar no plano narrativo, portanto, forçoso é demonstrar como se dá sua sintaxe funcional no conjunto da obra.

\subsubsection{O tao do antissujeito}

Ao tratar da categoria actancial do antissujeito, Tomasi (2012) especifica de maneira simples e clara esse recurso disponível da semiótica que outorga ao pesquisador um modelo de análise preciso e livre de juízos de valores pessoais ou extra-textuais, respeitando o primado da imanência do texto, "[...] podemos verificar a conveniência da utilização dos termos "sujeito" e "antissujeito", visto que ambos permitem uma abordagem livre de juízo moralista [...] A abordagem semiótica permite que se aflorem efeitos de sentido que de outra forma poderiam ficar submersos" (TOMASI, 2012, p. 86).

Situando essa outra categoria de sujeito no devido lugar da análise, é necessário antes partir do ponto que demonstre quais seriam, necessariamente, antissujeitos e antiobjetos postos no discurso de ARN: nada mais são que uma "aristocracia"51 ligada a

\footnotetext{
50 "A última forma narrativa simples que expressa a transformação dos valores positivos em valores negativos, ou o contrário, não pôde nem mesmo ser esboçada, pois seu exame nos teria obrigado a postular a existência de um antissujeito e de um antidestinador, o que parece evidente intuitivamente, mas cujo estabelecimento, no escopo de um projeto que se quer científico, ao menos pela coerência interna, que exige a interdefinição de todos os conceitos utilizados, não é simples.” (GREIMAS, [1983] 2014, p. 59).

${ }^{51}$ As aspas foram inseridas na versão corrigida desta dissertação, pós-defesa, uma vez que um dos membros da banca, a Profa. Dra. Laura V. Mattos, docente da FEA, levantou certas restrições na escolha de tal termo para se referir a um grupo de determinados indivíduos que se valiam de estratagemas e manobras políticas para a obtenção e permanência de seu poder e influência.
} 
determinados ramos da indústria, comércio e de razoável ou muita influência social e política. Há que se ter atenção sobre a menção de sua autoridade moral sociopolítica visto que, em muitos casos, esse clube de senhores da elite, quando não eram membros diretos dos legisladores da Inglaterra - parlamentarista há pouco menos de um século - eram ligados a órgãos de chancela de leis, sindicatos de patrões e até mesmo com o poder executivo local e à coroa.

Tais pessoas pleiteavam cargos e posições que lhes dessem plenos poderes para manipular as regras e as leis do trabalho e da administração pública. Assim Adam Smith os apresenta:

O estadista que tentasse orientar pessoas particulares sobre como devem empregar seu capital não somente se sobrecarregaria com uma preocupação altamente desnecessária, mas também assumiria uma autoridade que seguramente não pode ser confiada nem a uma pessoa individual nem mesmo a alguma assembleia ou conselho [...] Todos eles consideram de seu interesse empregar toda sua atividade de forma que aufiram alguma vantagem sobre seus vizinhos, comprando com uma parcela de sua produção - ou, o que é a mesma coisa, com o preço de uma parcela dela - tudo o mais de que tiverem necessidade. (SMITH, [1776] 1996, pp. 438-439)

Previamente se instala um grupo minoritário em que o interesse traz benefícios somente a si próprio e não para o todo, como pensado e postulado logo no início da obra e da análise, um sujeito nação e um objeto riqueza tratados em um enunciado elementar de estado, em que se estabelece uma função que lhes confere existência semiótica $\mathrm{F}\left(\mathrm{S}_{\mathrm{Nação}}\right.$, $\left.\mathrm{O}_{\text {riqueza }}\right)$. Tal e qual o enunciado de estado acerca da nação, há o seguinte enunciado elementar do antissujeito: $\mathrm{F}\left(\mathrm{S}_{\text {aristocracia }}, \mathrm{O}_{\text {riqueza }}\right)$.

De antemão se vislumbra no horizonte da análise um segundo tipo de enunciado elementar que trata da transformação, o qual automaticamente produzirá um sintagma elementar de ossatura do programa narrativo, com o caráter da transferência de valores, como já aludido anteriormente (GREIMAS, [1983] 2014, p. 48), visto que há uma transitividade entre dois sujeitos orientados para um mesmo objeto, sintagmatizados num enunciado do tipo "expropriação". 


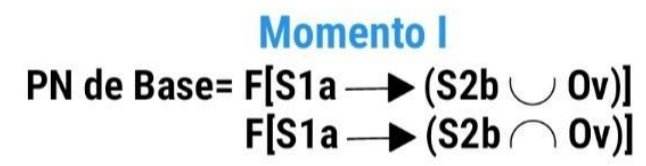

F: produzir/ trabalhar S1a: trabalhador S2b: Nação Ov: riqueza

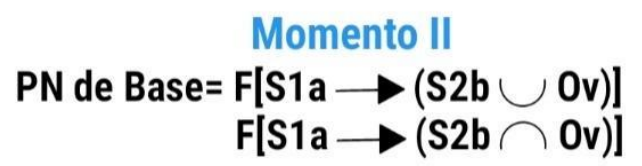

F: servir/ trabalhar S1a: colônia S2b: Aristocracia Ov: riqueza

Por conta do estabelecimento de dois enunciados paradigmáticos, em que há sujeitos distintos "de posse de" (realizado) ou em "direção a" (virtualizado) um mesmo objeto, consequentemente se cria uma relação antissubjetal entre os actantes.

Além disso, é importante relembrar que S2 (nação) só entra em conjunção com seu objeto quando da participação de um sujeito fundamental para o programa narrativo de transformação, a ação protagonista do trabalhador para a produção de bens, sobremodalizado por três competências essenciais: poder-fazer, saber-fazer e saber-saber.

Em contrapartida, o antissujeito aristocracia depende do trabalho restrito e controlado de suas corporações e da exploração servil e escravagista de suas colônias, sempre modalizando esses sujeitos através da sobremodalização exógena de um deverser/não poder-ser, já que sua principal fonte de riqueza se dá muito pouco da produção de bens e muito mais da obtenção de metais de suas minas e a condição exploratória de matéria-prima de outros países, o que também é evidenciado pela crítica do próprio autor, já que riqueza positiva para uma sociedade de mercado não se faz por conta da apropriação da prata ou do ouro, mas do trabalho e seu poder de troca:

\footnotetext{
As minas mais abundantes de metais preciosos ou de pedras preciosas pouco poderiam acrescentar à riqueza do mundo. Um produto cujo valor principal deriva de sua raridade é necessariamente desvalorizado por sua abundância. Uma baixela de prata e os outros frívolos ornamentos de vestuário e mobiliário poderiam ser comprados por uma quantidade menor de trabalho ou por uma quantidade menor de mercadorias. (SMITH, [1776] 1996, p. 210)
}

Cria-se outro problema para a análise: se a lógica do objeto no mercantilismo é o fechamento de seu mercado e a obtenção, supervalorização e a exploração de metais através de colônias, a do liberalismo posto em discurso é a abertura para importações, a aplicação do dinheiro em papel e o fomento do trabalho e das formas de aprimoramento de sua produção. Tem-se, portanto, dois objetos de valor distintos em essência.

A questão que advém é, como seria possível afirmar uma relação de expropriação objetal entre dois actantes, sendo que seus objetos de valor são diferentes? Teoricamente, o 
sujeito que desejasse um objeto A, e outro o objeto B, em nada interfeririam no processo de transformação de seus enunciados. Para responder essa questão que se abre, convocam-se três premissas sobre a condição do objeto: (i) os objetos só podem se tornar cognoscíveis em razão de suas determinações e não por si mesmos; (ii) essas determinações só podem ser apreendidas como diferenças que se projetam sobre o objeto, pois é esse caráter diferencial que lhes confere o estatuto de valor linguístico; (iii) mesmo permanecendo incognoscível enquanto tal, o objeto é, entretanto, pressuposto como uma espécie de suporte para a existência de valores (GREIMAS, [1983] 2014, p. 39).

Os elementos sintáxicos que provocam essa relação entre sujeito e antissujeito não são necessariamente os sujeitos de estado em seus enunciados elementares juntivos (nação e aristocracia), mas sim os sujeitos de transformação (trabalhador e colônia) com suas próprias sobremodalizações:

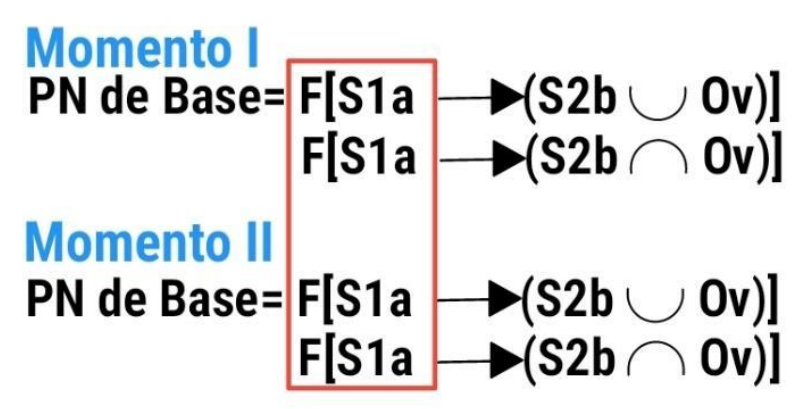

não poder-ser/dever-ser x poder não-ser/não dever não-ser

Enquanto o trabalhador de um sistema econômico liberal tem menos restrições e maior liberdade dentro de um espectro de estrutura modal da contingência e da possibilidade (poder não-ser/ não dever não-ser), já no reino colonizador ${ }^{52}$, tanto o escravo da colônia quanto os mestres e aprendizes de ofício operam sob a modalização da impossibilidade e da necessidade (não poder-ser/ dever-ser).

Soma-se isso às mencionadas restrições legalistas ${ }^{53}$ e o enunciado final será constituído por um PN de base que estabelece a conjunção de um objeto de valor riqueza

\footnotetext{
52 Optou-se por usar o termo "colônia” apenas com fins didáticos de análise por falta de escolha melhor para representar tanto os escravos e trabalhadores da colônia, quanto do próprio país colonizador.

53 "A duração habitual da aprendizagem na Escócia é de três anos, mesmo em certas profissões muito qualificadas; de modo geral não conheço nenhum país europeu onde as leis corporativistas sejam tão pouco opressivas." (SMITH, [1776] 1996, p.166).
} 
com um antissujeito aristocracia, produzindo automaticamente, em paradigma, uma disjunção catastrófica de um sujeito nação e seu objeto de valor bens.

Portanto, o antissujeito aristocracia (mercantilismo) atua sobremaneira através de um regime de impedimentos nas próprias relações de trabalho que se consolidavam naquela Inglaterra pós-revolução gloriosa, agindo de forma a limitar os espaços e os lugares de ocupação de todas as classes de trabalhadores:

Primeiramente, a política vigente na Europa gera uma desigualdade muito ponderável no conjunto global das vantagens e desvantagens dos diversos empregos de mão-de-obra e de capital, ao restringir a concorrência, em algumas profissões, a um número menor de pessoas do que aquelas que de outra forma poderiam estar dispostas a participar dela. (SMITH, [1776] 1996, p.164)

Daí que o resultado narrativo demonstra como ambos os sujeitos não podem coexistir sem que um afete o outro sintaticamente em relação ao seu próprio objeto, visto que, na modalidade do fazer de cada sujeito (ser-fazer) estão inscritas sobremodalizações de categorias opostas: o sujeito de fazer do mercantilismo se encontra num regime exotáxico, menos ativo, já que suas sobredeterminações são todas de ordem coercitiva e externa a ele, ao passo que o sujeito construído no discurso liberal é da categoria sobremodal endotáxica, mais ativo, devido a um interesse próprio que o move em direção ao objeto, além deste, é claro.

Esse interesse, sintagmatizado na obra como a famosa "mão invisível" terá sua atenção e análise mais adiante, já que é princípio inconteste da teoria de Adam Smith.

\subsection{Nível Discursivo}

\subsubsection{O enunciador}

O enunciador de A Riqueza das Nações assume uma posição actancial discursiva subjetiva e dialógica no quadro geral da obra. A fim de demarcar a instalação de um sujeito discursivo que se ancora no tempo e no espaço dos enunciados produzidos na manifestação do texto, essa voz se posiciona referenciamente de duas formas, em pessoa, temporalidade e espaço: o agora e o aqui, integrando assim a tripartição com o $e u$ na chamada debreagem 
enunciativa, quanto o então e o lá, assumidos juntamente com a terceira pessoa ele, na debreagem enunciva.

Entretanto, a suspeita é que tal obra se valha de uma aproximação muito mais da enunciação enunciada (enunciva) que a enunciativa. Essa "hipótese" discursiva assumida se dá por conta das próprias características do gênero da obra, pois a Economia Política tem como objetivo o estudo metodológico, crítico e orientado sobre a manutenção dos recursos de um país pelos próprios governantes, e pelo e para o povo ${ }^{54}$, leia-se, o enunciador é um sujeito que precisa estar diretamente conjugado com o tempo e o espaço de seu objeto semiótico, o organismo econômico de um dado lugar, para que possa lançar mão de uma ou todas as modalidades possíveis enquanto sujeito, seja asseverar e emitir julgamentos (serser), otimizar o campo de ação de outro(s) sujeito(s) do discurso (ser-fazer), persuadir/dissuadir sujeitos de forma a realizarem atos concretos (fazer-fazer) ou propriamente realizar atos de ordem cognitiva ou pragmática (fazer-ser), tudo dentro dos limites possíveis de transformações dos enunciados por ele, enunciador, enunciados.

Além disso, não se trata de um enunciador-autor historicista, que observa e registra seu entorno, narrativizando fatos, mas sim daquele que se vale de outros enunciados sobre fatos pretéritos para embasar sua argumentação, ou seja, dar reforço ao seu fazer epistêmico.

Ao apresentar, por exemplo, um dado sobre o lastro da moeda na Roma ${ }^{55}$ antiga, ou comparar os valores distintos de bens semelhantes através de personagens épicos, como Diomedes $^{56}$, o enunciador smithiano procura, muito além de registrar um episódio histórico, com sua sintaxe subjacente, por em prática uma estratégia argumentativa para se chegar ao objeto discursivo fim.

Para que se compreenda melhor tal artifício discursivo, Fiorin apresenta um dos conceitos mais frequentes na tipologia dos procedimentos argumentativos vários existentes ao tentar convencer o enunciatário: a ilustração. Eis:

\footnotetext{
54 “A Economia Política, considerada como um setor da ciência própria de um estadista ou de um legislador, propõe-se a dois objetivos distintos: primeiro, prover uma renda ou manutenção farta para a população ou, mais adequadamente, dar-lhe a possibilidade de conseguir ela mesma tal renda ou manutenção; segundo, prover o Estado ou a comunidade de uma renda suficiente para os serviços públicos. Portanto, a Economia Política visa a enriquecer tanto o povo quanto o soberano." (SMITH, [1776] 1996, p. 411)

55 "Na época de Sérvio Túlio, o primeiro a cunhar moedas em Roma, o asse ou pondo romano continha 1 libra romana de cobre de boa qualidade”. (SMITH, [1776], 1996, p.84).

56 "A couraça de Diomedes, afirma Homero, custou somente 9 bois, ao passo que a de Glauco custou 100 bois". (SMITH, [1776], 1996, p.82).
} 
No procedimento da ilustração, o narrador enuncia uma afirmação geral e dá exemplos com a finalidade de comprová-la. (FIORIN, 2009, p. 75)

Portanto, ilustrar o problema da cunhagem das moedas em metais preciosos e a sua desvalorização na Roma do século V a.C. e comparar o preço de duas embarcações pela cabeça de bois é, respectivamente, na imanência do discurso, acusar a desvalorização do metalismo corrente de seu tempo e afirmar a funcionalidade da DIT ao diversificar os tipos de trabalho, criando consequentemente uma moeda "comum" a todos, eliminando o escambo.

O seu objetivo discursivo se cumpre assim, pondo na sua prática o estabelecimento de um contrato fiduciário de veridicção acerca dos efeitos de verdade criados pela voz enunciadora, para usar um termo caro aos estudos do discurso, uma espécie de "dizerverdadeiro", (BARROS, 2002, p. 94) já que não há uma verdade estabelecida no discurso, mas em estratégias de se dizer a verdade.

\subsubsection{O assalariado}

Em ARN é possível notar, no transcorrer do texto, um enunciador smithiano o qual formaliza através de seu discurso manipulações e, sobretudo, sanções sobre os atores diversos da obra: o trabalhador, o investidor, o mercantilismo e até mesmo sobre o próprio enunciado.

Percebe-se então actantes discursivizados que denunciam a enunciação e possuem um papel análogo ao de Destinatário e Destinador ${ }^{57}$ (sujeitos da sintaxe na etapa de transferência de valores), só que, neste nível discursivo, sujeitos da comunicação que transferem e recebem a fala do outro como objeto.

Ao tratar da Divisão do Trabalho, e de sua potencialização na produção dos bens, o enunciador se vale de algumas estratégias argumentativas para convencer seu enunciatário acerca da aplicabilidade necessária dessa lógica de produção, dividindo sua crítica tanto aos investidores, atorializados na obra como donos de fábricas e demais atores que fazem parte

\footnotetext{
57 Deve-se, então, distinguir, entre os actantes, os actantes narrativos, propriamente ditos, dos actantes discursivos, que são também narrativos, mas pertencem à estrutura narrativa da enunciação. Os actantes do discurso instalam-se como projeções da enunciação e simulam os papéis actanciais assumidos pelo sujeito da enunciação (sujeito e destinador/destinatário). (BARROS, 2002, p.80).
} 
de uma isotopia temática do "patronado", quanto ao trabalhador, atorializados como operários das fábricas, alfaiates, agricultores de uma isotopia do "assalariado".

Em relação a esses últimos, além de se valer de um recurso da desembreagem enunciativa de pessoa, tornando responsável pelo discurso outro sujeito que não o da enunciação ( $3^{\mathrm{a}}$ pessoa, ela), de modo a se distanciar da subjetividade já latente e que por vezes se assume no texto, ainda assim o enunciador emite uma sanção cognitiva negativa sobre o ser do trabalhador a partir daquilo que assume como uma performance mal sucedida.

Esse enunciado de insucesso se dá justamente por ter de dividir o seu fazer em várias etapas na confecção e fabricação dos bens, o que acaba por descompetencializar o sujeito, subtraindo-lhe o poder-fazer em detrimento de um saber-fazer global, traduzindose discursivamente, tirando-lhe a capacidade de eficiência na produção do bem em troca da capacidade de domínio total na elaboração de seu produto, da primeira à última etapa do processo. Assim se diz:

Ao começar o novo trabalho, raramente ela [pessoa] se dedica logo com entusiasmo; sua cabeça "está em outra", como se diz, e, durante algum tempo ela mais flana do que trabalha seriamente. [...] quase sempre o torna indolente e preguiçoso, além de fazê-lo incapaz de aplicar-se com intensidade, mesmo nas ocasiões de maior urgência. (SMITH, [1776] 1996, p. 69).

Observa-se aí que a indolência e a preguiça são as duas sanções negativas sobre o ser do trabalhador que ainda faz parte do modelo arcaico e retrogrado de trabalho em um mundo que ainda se vê às voltas de uma estrutura econômica predominantemente colonialista mercantilista.

Através desse julgo, o enunciador deixa clara a linha pluri-isotópica temática que perfila a noção de trabalho executado fora dos moldes da DIT, como "ineficiência da 
globalidade sobre as formas de produção" 58, "selvagem e primitivo" 59 e "produção tipicamente agrícola" 60 .

\subsubsection{O patronato}

Ainda sobre o mesmo enunciador-D ${ }^{\text {or }}$, como já exposto anteriormente, este assume uma estratégia de manipulação cognitiva direta, através de uma atualização do crer, abrindo automaticamente uma janela discursiva das modalidades epistêmicas sobre o ser do crer de seu enunciatário- $\mathrm{D}^{\text {ario }}$.

De maneira análoga ao fazer-fazer do $\mathrm{D}^{\text {or }}$-actancial narrativo, tal fazer constitui-se como uma performance cognitiva entre enunciador e enunciatário ainda mais complexa que aquela sobremodalizadora entre sujeitos, uma vez que, se bem sucedida, essa comunicação de objeto só será efetivamente realizada não somente por um mero fazer-saber acerca do caráter e os objetivos dos donos de fábrica e seus sindicatos, mas também por um fazer-crer sobre a veracidade em si de tal enunciado.

Sua complexidade vai ainda mais adiante, uma vez que o crer é uma modalidade que envolve também um fazer de seu enunciatário, denominado fazer-interpretativo, já que este necessariamente aceita ou não o objeto comunicado pelo outro. Sobre esse ato epistêmico, Barros discorre da seguinte maneira:

O fazer interpretativo é, também, um fazer cognitivo e consiste em modalizar um enunciado pelo parecer e pelo ser e em estabelecer a correlação entre os dois planos da manifestação e da imanência. (BARROS, 2002, p. 55)

Para que essa performance se concretize, o procedimento de focalização se estabelece por uma debreagem actancial implícita (COURTÉS \& GREIMAS, [1986] 2008,

\footnotetext{
58 "Cada indivíduo torna-se mais hábil em seu setor específico, o volume de trabalho produzido é maior, aumentando também consideravelmente o cabedal científico". (Smith, [1776] 1996, p. 70).

59 "Entre nações selvagens e primitivas, a centésima parte — ou pouco mais — do trabalho de todo o ano será suficiente para prover de vestimenta e moradia satisfatórias a maior parte do povo. As outras noventa e nove partes muitas vezes mal são suficientes para suprir esse povo de alimentos. Entretanto, quando, em razão do aprimoramento e do cultivo da terra, o trabalho de uma família é capaz de produzir alimentos para duas, basta o trabalho da metade da sociedade para prover de alimentos o país inteiro". (SMITH, [1776] 1996, p. 202).

60 “As nações mais opulentas geralmente superam todos os seus vizinhos tanto na agricultura como nas manufaturas; geralmente, porém, distinguem-se mais pela superioridade na manufatura do que pela superioridade na agricultura.” (SMITH, [1776] 1996, p. 67).
} 
p. 189), um observador que sabe do conluio $^{61}$ do patronado, postulando uma crítica ainda mais incisiva aos atores donos de fábrica e de demais grandes negócios:

Os patrões, por serem menos numerosos, podem associar-se com maior facilidade; além disso, a lei autoriza ou pelo menos não os proíbe, ao passo que para os trabalhadores ela proíbe. Não há leis do Parlamento que proíbam os patrões de combinar uma redução dos salários; muitas são, porém, as leis do Parlamento que proíbem associações para aumentar os salários. [...] Essas combinações sempre são conduzidas sob o máximo silêncio e sigilo, que perdura até o momento da execução; e quando os trabalhadores cedem, como fazem às vezes, sem resistir, embora profundamente ressentidos, isso jamais é sabido de público. (SMITH [1776] 1996, p. 119).

Com a finalidade de reforçar ainda mais o "efeito de verdade" do argumento, o enunciador apresenta duas linhas isotópicas distintas para figurativizar a relação de causa e consequência de seu discurso: a proporcionalidade, pois, por estarem em menor número que os trabalhadores, ainda assim o poder de sua ação é maior e ainda mais eficiente ao se organizarem em grupos; e a legitimidade jurídica, já que não há impedimento determinado por lei alguma, nada que os impeça.

Logo, há um sujeito enunciador competente e complexo, atualizado por um saber, executando uma performance sobremodalizadora do fazer-saber e fazer-crer, e que, no percurso de seu fazer transformador sobre o fazer-interpretativo de seu $\mathrm{D}^{\text {ario }}$-enunciatário, emite um enunciado revelador das práticas escusas de outros sujeitos da cena enunciativa por ele comunicada, ou seja, o enunciador finalmente torna realizado seu objeto comunicado ao sancionar o conluio através da modalidade veridictória do ser, no caso, operando na dêixis do segredo: não-parecer + ser.

O enunciador completa, portanto, mais um de seus percursos vários para ratificar os problemas inerentes da estrutura sócio-econômica do sistema vigente em seu tempo.

\subsubsection{O enunciador sobre Adam Smith}

Embora pouco profícuo aos objetivos do trabalho, parece importante salientar outro ponto sobre as debreagens realizadas do enunciador com vias de sedimentar ainda mais seu

\footnotetext{
${ }^{61}$ Termo usado pelo próprio Adam Smith.
} 
próprio discurso, causando o efeito de credibilidade naquilo que diz. Através da debreagem enunciativa, o actante discursivo se ancora desta vez em um espaço, tempo e pessoa próximos da instância da enunciação, com fins de se erigir um sujeito legitimado não só pelo saber teórico de suas ideias, mas do ser prático de sua vivência compartilhada no mesmo espaço discursivo de seu enunciatário contemporâneo. Com certa frequência o enunciador não somente expressa essa pertença aos próprios enunciados, como também produz uma auto-crítica sobre o próprio discurso:

Estou sempre disposto a correr um certo risco de ser tedioso, visando à certeza de estar sendo claro; e após fazer tudo o que puder para ser claro, mesmo assim poderá parecer que resta alguma obscuridade sobre um assunto que, aliás, é por sua própria natureza extremamente abstrato. (SMITH, [1776] 1996, p. 88)

Os fatos e argumentos que acabei de mencionar levam-me a crer - ou melhor, a suspeitar e conjecturar - que, apesar dessa redução, o valor da prata, durante o curso do século atual, começou a subir um pouco no mercado europeu; (SMITH, [1776] 1996, p. 243)

Assim, a debreagem enunciativa é o mecanismo em que se projeta no enunciado as pessoas, o tempo e o espaço da enunciação, quer a pessoa, o tempo e o espaço do enunciado (FIORIN, 2009, p. 58). Ainda que, como já demonstrado, o enunciador smithiano tem na predominância de seus atos discursivos um sujeito competencializado, sancionador e manipulador, sem embargo ele avalia e sanciona o próprio discurso, realizando assim, ora uma debreagem enunciva, ora enunciativa.

\subsubsection{O sancionador smithiano}

Em outro trecho, ainda assumindo essa voz discursiva que assevera conclusões e asserções sobre a "realidade" que o cerca, o enunciador executa um interessante movimento de debreagem enunciativa temporal dentro das suas várias marchas linguísticas possíveis. Como já explicitado didática e elegantemente por um dos maiores nomes dos estudos discursivos, Fiorin (2009, p. 59), há três momentos de referência: um concomitante ao agora (o presente); um anterior ao agora (pretérito) e um posterior ao agora (futuro), sendo subcategorizados em concomitância vs. não concomitância e anterioridade vs. posterioridade. 
No capítulo "Efeitos diferentes do avanço do desenvolvimento sobre três diferentes tipos de produtos naturais" (p. 244-262), o enunciador estabelece três tipos de produtos os quais são suscetíveis ao trabalho humano em maior ou menor nível, ou seja, que já matérias primas podem ser mais ou menos afetadas pela ação e a tecnologia do homem. Seguindo por essa linha de raciocínio, o enunciador executa uma de suas várias performances discursivas, pondo mais uma vez em prática linguageira seu projeto - ou um dos - que trata da crítica ao metalismo e sua consequente exploração das minas de metais preciosos, manifesto em texto, vigente e contemporâneo àquela voz enunciativa.

Para que se entenda melhor o excerto, basta saber que o enunciador propõe um exercício imaginativo em que, ainda que exista a mina de ouro mais rica da mundo a ser descoberta, ou que as minas a serem descobertas sejam menos abundantes que as já exploradas até então, tal e qual cenário em absolutamente nada mudariam a tese de que os países mais ricos são aqueles que possuem o poder-fazer de seus atores trabalhadores, pois o valor do trabalho e do produto agrícola sempre são os mesmos ${ }^{62}$. Assim:

Qual desses dois eventos ou hipóteses ocorre efetivamente, isto tem muito pouca importância para a riqueza e prosperidade real do mundo, para o valor real da produção anual da terra e do trabalho da humanidade. Sem dúvida, seu valor nominal, a quantidade de ouro e prata pela qual essa produção anual poderia ser expressa ou representada, seria muito diferente; mas seu valor real, a quantidade real de trabalho que poderia comprar ou comandar seria exatamente a mesma. (SMITH, [1776] 1996, p. 262)

O "eu", automaticamente instaurado no discurso de ARN, projeta-se fora de seu momento de referência presente, concomitante ao agora da enunciação, para se realocar em um momento de referência pretérito e não concomitante posterior, o chamado futuro do pretérito, expresso em "seria". Lançando mão desse recurso, o enunciador manipula o fazer-crer de seu enunciatário, aparecendo aí a configuração de um Destinador discursivo competencializado de tal maneira que, pode e sabe demonstrar até mesmo as possíveis e prováveis resoluções dos países que adotarem esse ou aquele modo de lidar com sua economia.

\footnotetext{
62 A fim de se compreender melhor o excerto em questão, Adam Smith divide o preço de serviços e bens em valores nominais e valores reais ([1776] 1996, p. 90). Estes possuem em seu lastro a quantidade imutável de operações físicas e/ou mentais para a produção de um determinado bem; aqueles, se baseiam no valor expresso em dinheiro, logo, subordinado a oscilações cambiais, inflacionárias e de outras variáveis mais complexas que influenciam valores diferentes para um determinado produto.
} 
Daí, portanto, um enunciador que cumpre com a etapa inicial e final de um Dor que manipula e sanciona seus discursos de modo a reforçar e transferir suas ideias sobre sujeitos e antissujeitos figurativizados em seu discurso como trabalhador, colonialismo, a Divisão do Trabalho e demais papeis.

\subsubsection{O interesse e a mão invisível em A Riqueza das Nações: uma abordagem narrativa e discursiva}

\subsubsection{A mão invisível e o senso comum}

Sem se ater ao tratamento epistemológico mais acurado, parece óbvio imaginar que toda "grande teoria" é, por excelência, difundida e popularizada de maneira mais ou menos especializada entre os integrantes de dentro e de fora de sua "bolha" científica. Seja a relatividade de Einstein, a investigação do inconsciente freudiano, ou o socialismo marxista, em diferentes graus, porém consideráveis, ideias e conceitos parecem se difundir consideravelmente no seio das comunidades científicas externas àquelas onde a própria teoria fora criada, chegando até mesmo ao paladar do gosto mais "popular".

Todo estudante de graduação sabe superficialmente ou já ouviu falar sobre a famosa fórmula de deslocamento da luz no espaço einsteniana, ou mesmo um matemático tem dada noção sobre a teoria psicanalítica de Freud.

Não seria diferente com o conceito de "mão invisível" e "individualismo" da teoria de Adam Smith, sendo essas duas ideias as mais disseminadas tanto por especialistas quanto por entusiastas da economia ou da ideologia liberal tradicional.

Com o intuito de propor um novo panorama de leitura, sem que se incorra na reinvenção da roda, e não se baseie a análise em sentidos superficiais de manuais "rápidos" ou até mesmo se percam em superinterpretações, propõe-se para este momento do trabalho um exame das estratégias discursivas e, principalmente, das estratégias narrativas para se chegar a um "resultado".

Segundo Barros (2002, p. 42), cabem a essas estratégias narrativas demonstrar de que maneira circulam os objetos entre seus sujeitos, em que tipos de programas narrativos aparecem e como se dão as junções, tudo com vistas ao discurso que logo ali virá. 
Antes de se prosseguir com o exame semiótico, lançando mão dessas duas maneiras de análise, é necessário reforçar que a construção de tais noções se deu antes mesmo de ARN, como por exemplo, a de individualidade, desde sua Teoria dos Sentimentos Morais ${ }^{63}$, e que, para efeito de uma análise historiográfica, seria necessário considerar um espectro mais amplo.

\subsubsection{A individualidade e a mão invisível em ARN}

Como já assumido na análise, tanto o sujeito mais englobante e geral "nação", quanto o mais específico e coletivo, "trabalhador", para ficar somente nesses, possuem em seus enunciados juntivos a existência virtualizada em relação a um objeto de valor distinto para cada um deles.

A questão é, ainda que haja actantes outros no percurso de cada um dos três atores/sujeitos principais de ARN, doadores de competências e sobremodalizações de modo a instrumentalizá-los e dotá-los de meios para se chegar ao seu objeto, em quais momentos do discurso e em que parte dessa estrutura sintáxica entraria o tão aludido interesse?

É necessário apresentar antes de tudo o excerto emblemático em que aparece unicamente o termo "mão invisível” em ARN:

Ao se analisar o enunciado onde se encontra o famigerado termo, percebe-se um actante discursivo smithiano o qual, ainda que plenamente competencializado (quer, sabe e pode-fazer) para atuar na sua busca em direção ao salário, lucro ou a renda da terra, não tem a consciência (saber-saber) de que seu fazer transforma outros enunciados e, como já visto, promovem direta e indiretamente a ascensão de outros sujeitos, afetando em último caso, na ponta da cadeia sintáxica do macro enunciado da obra, a nação.

Essa rede de enunciados de fazer e de estado, que afetam e são afetados, possui como força motriz o interesse de ordem do foro mais íntimo do indivíduo prescrito na teoria liberal, em que ele, o próprio indivíduo, naturalmente persegue e promove objetos tais em seu benefício ${ }^{64}$ :

\footnotetext{
63 "Portanto, todo homem está muito mais profundamente interessado no que diz respeito imediatamente a si, do que no que diz respeito a outro homem qualquer" (SMITH [1759] 1999, p. 103).

64 “Aliás, nem sempre é pior para a sociedade que esse objetivo não faça parte das intenções do indivíduo. Ao perseguir seus próprios interesses, o indivíduo muitas vezes promove o interesse da sociedade muito mais eficazmente do que quando tenciona realmente promovê-lo" (SMITH, [1776] 1996, 438).
} 
Com efeito, o que o indivíduo tem em vista é sua própria vantagem, e não a da sociedade. Todavia, a procura de sua própria vantagem individual natural ou, antes, quase necessariamente, leva-o a preferir aquela aplicação que acarreta as maiores vantagens para a sociedade. (SMITH, [1776] 1996, p. 436)

Além do aspecto individual de cada sujeito, ao ser coletivizado, o interesse é exposto na obra como que classificada e tipificada dentro dos três tipos de atores da produção de riqueza do país, além de ser um fator de dissensão entre as classes ${ }^{65}$ :

Essas são as três grandes categorias originais [senhor de terras, trabalhador e investidor] constituintes de toda sociedade evoluída, de cuja receita deriva, em última análise, a renda de todas as demais categorias. [...] O interesse da segunda categoria - a dos que vivem de salário está tão intimamente vinculado ao interesse da sociedade como o da primeira. (SMITH, [1776] 1996, p. 272-273)

Sendo assim, para se compreender o lugar semiótico da mão invisível e do interesse, a começar sobre este último, sobremaneira mencionado e/ou aludido no corpus de análise, trata-se da modalidade volitiva do querer sobre o ser e o fazer do sujeito em relação ao objeto valor.

Tanto o querer-fazer quanto o querer-ser são os elos da cadeia sintática entre o funtivo subjetal e objetal, responsáveis por uma transformação virtualizante e que sem os quais resultaria na abolição da existência semiótica e devolveria os objetos ao caos semântico original (GREIMAS, [1983] 2014, p. 41).

Essa existência semiótica é a própria relação imanente e indissociável entre sujeito e objeto, estabelecida pelo enunciador, garantidora do enunciado elementar estabelecido entre ambos, o qual se desdobrará em tantos outros enunciados. Em Semiótica e Ciências Sociais Greimas se refere assim à existência semiótica:

A existência semiótica, portanto, não deve ser confundida com a existência "verdadeira", e o caráter verídico de nossas asserções deve ser distinguido de nossa competência verbal para produzir tais asserções. [...] Ainda mais: esta consolidação da existência semiótica, se aparece como

\footnotetext{
65 Smith trata de uma luta de classes em que não haveria motivações mais ou menos nobres, sendo tão somente partes litigantes de seus próprios interesses, extremados por vezes: "Quais são os salários comuns ou normais do trabalho? Isso depende do contrato normalmente feito entre as duas partes, cujos interesses, aliás, de forma alguma são os mesmos. Os trabalhadores desejam ganhar o máximo possível, os patrões pagar o mínimo possível” (SMITH, [1776] 1996, 118).
} 
uma caução suplementar, só pode ser uma tomada de posição efetuada pelo sujeito da enunciação a respeito de seu enunciado. (GREIMAS, [1975] 1981, p. 12)

A partir dessa tomada de posição teórica, parece legítimo assumir que, se há instâncias mais ou menos distantes dos limites entre níveis, haveria então um enunciado narrativo mais elementar da obra, representativo de toda a intenção do texto, e que sincretiza actancialmente os inúmeros atores da obra, trabalhador, nação, salário, lucro, etc.:

\author{
$\mathrm{F}=\mathrm{S} 1 \rightarrow(\mathrm{S} 2 \cap 0)$ \\ S1: indivíduo 0: objeto individual S2: indivíduo \\ F: Interesse $\quad$ - : querer ser/ter
}

É o interesse, termo modal proeminente no discurso smithiano, articulado tanto na estrutura modal entre enunciados, quanto inscrito como valor nos próprios objetos, que se apresenta como fator primordial para as transformações juntivas dos sujeitos que querem ser ou ter seu objeto.

Além disso, é dever do Estado cuidar para que o interesse desses sujeitos não interfira/sofra interferência por conta dos interesses de demais sujeitos ${ }^{66}$, como apresentada de maneira clara no seguinte excerto:

Ora, o interesse dos negociantes, em qualquer ramo específico de comércio ou de manufatura, sempre difere sob algum aspecto do interesse público, e até se lhe opõe. $\mathrm{O}$ interesse dos empresários é sempre ampliar o mercado e limitar a concorrência. Ampliar o mercado muitas vezes pode ser benéfico para o interesse público, mas limitar a concorrência sempre contraria necessariamente ao interesse público, e só pode servir para possibilitar aos negociantes, pelo aumento de seus lucros acima do que seria natural, cobrar, em seu próprio benefício, uma taxa absurda dos demais concidadãos. (SMITH, [1776] 1996, p. 273)

\footnotetext{
${ }^{66}$ No livro II, capítulo 2, de "Teoria dos Sentimentos Morais", o autor apresenta desde lá uma crítica severa aos que se aproveitam ou subjugam o outro em benefício próprio, ainda que seja da natureza do ser preferir primeiramente o próprio bem estar que do outro: "Perturbar sua [do próximo] felicidade tão somente porque no caminho da nossa própria, tirar dele o que é seu verdadeiro apenas porque pode ter igual ou maior uso para nós, ou permitir-nos, dessa maneira, à custa de outras pessoas, a preferência natural que todo homem tem por sua felicidade acima da dos outros, constitui algo ao qual nenhum expectador imparcial pode aceder." (SMITH [1759] 1999, p. 102).
} 
Ou seja, a despeito de suas múltiplas intencionalidades e do fazer dos mais variados sujeitos em busca de seus mais variados objetos, esse elemento primordial da expressão semiótica por vezes é confundido ou subvertido em valores como egoísmo e ganância.

Eis que a tensão entre interesse de todos vs. interesse de poucos advém automaticamente projetada no jogo de tensões já apresentado entre liberalismo vs. mercantilismo, projetando valores que podem ser articulados nas mesmas dêixis daquele quadrado.

Uma última observação se faz necessária: mais uma vez é possível perceber, através do primeiro excerto desta parte do trabalho, como o próprio enunciador projeta o sujeito trabalhador na malha de seu discurso, aproximando-o numa clara relação semântica de ordem metonímica: o interesse do trabalhador é, em termos, o interesse da nação, eis que, por isso mesmo, o sujeito trabalhador é reafirmado como actante necessário no esquema narrativo da obra.

\subsubsection{Do interesse, da liberdade e do mercado}

Quando da análise acerca dos termos presentes nessa rede mais superficial de significações constantemente defendida pelo enunciador, percebe-se que existe uma padronização semântica constante na organização do sentido, verificada pelo revestimento posto no discurso de seu enunciador, fazendo aparecer assim as chamadas isotopias.

São elas que garantem a possibilidade das várias leituras por conta das virtualidades significativas presentes no texto (FIORIN, 2009, p.112).

Há, portanto, bases classemáticas que organizam os núcleos sêmicos no nível discursivo e que faz aparecer essa organização temática no texto de Adam Smith. Antes de se prosseguir com a apresentação das isotopias subjacentes ao texto, propõem-se então três grandes temas correntes em ARN: a "autonomia do mercado", "a liberdade individual" e o "interesse próprio", como sendo as pedras de toque da teoria.

Veja-se, por exemplo:

A propriedade que cada pessoa tem em sua própria ocupação, assim como é o fundamento original de toda e qualquer outra propriedade, da mesma forma constitui a propriedade mais sagrada e inviolável [...] Assim como se impede o trabalhador de trabalhar como lhe parecer mais indicado, da 
mesma forma impede-se os outros de empregar a quem considerarem mais oportuno. (SMITH, [1776] 1996, p. 166-167)

Assumir que os sujeitos individuais (cada pessoa) podem escolher sua ocupação e se apropriar desta, comparando-a com o sacro direito à propriedade privada (propriedade sagrada), utilizando-se para isso do recurso temporal do presente gnômico, faz produzir um efeito de sentido que marca a perenidade de tudo aquilo que de fato é do campo do sagrado, incólume ao tempo e ao homem.

O enunciador marca ainda a posição enunciativa do sujeito "assunto" e, através de uma debreagem enunciva, transfere o fazer do discurso para o próprio fazer cognitivo sancionador do sujeito trabalhador através do verbo reflexivo "parecer (lhe)".

Ao verificar tais pontos levantados, as isotopias abstratas do /individualismo/, /direito/, /privado/ e da /liberdade/ vêm e o resultado da soma desses núcleos sêmicos é a isotopia temática da "liberdade individual".

Além disso, observa-se também a prática de um regime de manipulação sobremodalizando o enunciatário através da intimidação (respeito ao imaculado, consagrado por "lei", divino) de maneira a equiparar a liberdade sobre o privado (poder poder-ter) com a autonomia para buscar seus meios de trabalhar com o que quiser (poder poder-ser).

Outro percurso temático encontrado em certo número de excertos da obra é o de "autonomia do mercado", geralmente ratificado com lexemas como "efeito natural", “produtos naturais", "vantagens comerciais”, "necessário e excedente”, “valor dos metais e valor do trabalho", para ficar apenas nesses.

Selecionou-se o seguinte trecho do corpus para apresentar tal isotopia:

Não há regulamento comercial que possa aumentar a quantidade de mãode-obra em qualquer sociedade além daquilo que o capital tem condições de manter. Poderá apenas desviar parte desse capital para uma direção para a qual, de outra forma, não teria sido canalizada; outrossim, de maneira alguma há certeza de que essa direção artificial possa trazer mais vantagens à sociedade do que aquela que tomaria caso as coisas caminhassem espontaneamente. (SMITH [1776] 1996, p. 435)

Já no jogo plurisotópico fundante do tema "autonomia do mercado" é possível visualizar a isotopia da /lógica do mercado/ (regulamento comercial; capital) direcionada pelos desígnios arbitrários de determinados poderes (direção artificial) e a outra que flui 
naturalmente (coisas caminhassem espontaneamente) sem que haja a interferência alguma no seu percurso.

Tem-se aí as duas isotopias disputando entre si o curso do mercado. A primeira, e mais nítida por conta do próprio trecho, é a do /Estado/ enquanto ente legislador e regulador das regras do jogo comercial.

A outra, não tão perceptível assim, advém do lexema coisas que, no contexto do próprio capítulo, refere-se ao trabalho e à empresa dos indivíduos vários que compõem a sociedade, formando assim a isotopia da /sociedade de mercado/. Esta deve se autoorganizar mercadologicamente de maneira natural e orgânica, havendo autonomia nesse tipo de processo, trazendo bons resultados à sociedade ${ }^{67}$, visto que o mercado é a grande metáfora das relações de troca e interesse entre os sujeitos.

A última isotopia temática encontrada, e tão importante quanto às outras - se não a mais - trata-se do "interesse próprio". Para este momento da exposição do corpus, selecionou-se dois trechos distintos os quais demonstram esse tema através da progressão de isotopias distintas. O primeiro deles é um dos mais emblemáticos citados em manuais e enciclopédias:

Não é da benevolência do açougueiro, do cervejeiro ou do padeiro que esperamos nosso jantar, mas da consideração que eles têm pelo seu próprio interesse. Dirigimo-nos não à sua humanidade, mas à sua autoestima, e nunca lhes falamos das nossas próprias necessidades, mas das vantagens que advirão para eles. (SMITH, [1776] 1996, p.74)

A sustentação do "interesse próprio" só é efetivada mediante a articulação das isotopias da /necessidade individual/ e da /autoestima/ sem as quais se torna impossível a realização de qualquer programa da sintaxe narrativa de ARN. O próprio enunciador assevera que é através de uma manipulação do sujeito pela tentação, estabelece-se um contrato fiduciário no qual há um objeto de valor que será dado (vantagens) em troca do objeto visado, seja esse objeto de valor o lucro, o juro, a renda, ou um bom salário, por exemplo.

Um pequeno desvio se faz pertinente: ao asseverar que não se deve esperar pela benevolência do outro, parece possível vislumbrar dois tipos possíveis de enunciados de

67 "Outorgar o monopólio do mercado interno ao produto da atividade nacional, em qualquer arte ou ofício, equivale, de certo modo, a orientar pessoas particulares sobre como devem empregar seus capitais - o que, em quase todos os casos, representa uma norma inútil, ou danosa." (SMITH, [1776] 1996, p. 438). 
transformação para cada um desses actantes do discurso exposto, um em realização transitiva (atribuição), o outro em realização reflexiva (apropriação) (GREIMAS, [1983] 2014, p. 49), ou seja, não há espaço no discurso smithiano para a virtualização transitiva (expropriação) e a virtualização reflexiva (renúncia):

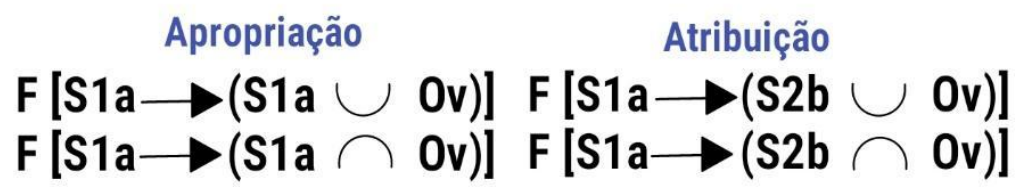

Assim, em termos figurativos tal como apresentado no excerto acima, e em demais recortes do corpus, graças à /necessidade/ e à /autoestima/, não se deve prever/haver no discurso liberal de Adam Smith indivíduos que cedam seus bens por livre e espontânea vontade pelo regime da generosidade (renúncia) e tampouco aqueles que tomam os bens dos demais, através da cupidez (expropriação).

Já em outro excerto, expõe-se não somente mais uma das várias ocorrências da isotopia abstrata do /interesse/, como também se reafirma e divide em demais isotopias, conforme a categoria do /interesse da classe trabalhadora/ de modo a ter uma relação direta com a isotopia do /interesse da sociedade/ frente ao /interesse de grupos/, aparecendo as figuras do investidor, patrão, políticos e demais minorias detentoras do poder:

\footnotetext{
Mas, embora o interesse da classe trabalhadora esteja intimamente ligado ao interesse da sociedade, o trabalhador é incapaz tanto de compreender esse interesse quanto de compreender a vinculação do interesse da sociedade ao seu próprio. Sua condição não lhe deixa tempo para receber a necessária informação, e sua educação e hábitos costumam ser tais que o tornam inapto para discernir, mesmo que esteja plenamente informado. [...] É proposta que advém de uma categoria de pessoas [empresários] cujo interesse jamais coincide exatamente com o do povo, as quais geralmente têm interesse em enganá-lo e mesmo oprimi-lo e que, conseqüentemente, têm em muitas oportunidades tanto iludido quanto oprimido esse povo. (SMITH, [1776] 1996, p. 272-273)
}

Consequentemente se chega à análise da famigerada "mão invisível”, lexema posto sem muitas ambições na estrutura do discurso de ARN e sobre o qual se propõe uma análise sêmica a fim de demonstrar sua operacionalidade com o tema do interesse próprio. Eis a conhecida passagem: 
Ao preferir fomentar a atividade do país e não de outros países ele [investidor] tem em vista apenas sua própria segurança; e orientando sua atividade de tal maneira que sua produção possa ser de maior valor, visa apenas a seu próprio ganho e, neste, como em muitos outros casos, é levado como que por mão invisível a promover um objetivo que não fazia parte de suas intenções. (SMITH, [1776] 1996, p.437)

Apesar do trecho se referir à atividade do investidor, visando seu objeto lucro, fazse uma ressalva, usando para isso as palavras do próprio enunciador, que alega ser a mão invisível um elemento da equação econômica que se relaciona com demais elementos (neste, e como em muitos outros casos), ou seja, amplia-se a influência dessa mão para demais sujeitos e situações.

Ao elencar os diversos usos para "mão", se tem as seguintes possíveis bases classemáticas (abstratas): trabalho (mãos à obra), instrumento (à mão armada), habilidade (mãos boas para), controle (com mão de ferro), posse (com as mãos vazias), auxílio (estender a mão).

Já o adjetivo "invisível" alça o termo o qual se junta às qualidades de indistinto (parede invisível), sobrenatural (homem invisível), irreconhecível (ameaça invisível), anonimato (aluno invisível), oculto (dispositivo invisível).

Quando articulado num texto que tem como tônica de seu discurso o tema "interesse próprio", parece lícito assumir que o termo mão invisível nada mais é que a metáfora figurativa mais emblemática desse tema, e que a seleção dos classemas como "controle", "posse" e "oculto" corroboram para a ideia de uma força que impulsiona e dirige o sujeito em seus programas em direção ao objeto, sem que para isso se tenha necessariamente consciência do estímulo que o leva a querer algo.

\section{CONCLUSÃO}

Com a finalização deste trabalho verifica-se, portanto, como e quanto o enunciador da obra deixa entendido e subentendido na e através da manifestação de seu discurso a relevância prática do trabalhador como ator primordial para o bem estar econômico de uma sociedade, mais especificamente, a nação.

Obviamente, a complexa trama social e os agentes responsáveis pela produção de riqueza em um país vão além do trabalhador, jamais podendo ser desconsiderados o senhor 
de terras e o investidor, como peças fundamentais para a construção dessa teoria tradicional da máquina do capitalismo em seu gérmen.

Parece ser também clara a ideia de que, aquilo que une esses três pilares no discurso liberal de Adam Smith é essa vontade metafísica postulada pelo autor como "interesse", analisado semioticamente como o próprio enunciado prático elementar de todos os sujeitos levantados no corpus de trabalho, representado metaforicamente pelo próprio autor como um misterioso poder condutor chamado "mão invisível". Ora, a título de conclusão de trabalho, ousa-se pensar também como sendo essa mão o elemento providencial divino, diversas vezes convocado pelo próprio autor, dentro e fora de ARN.

Ademais, o que se amplia e postula aqui é como a teoria da análise semiótica greimasiana, com as suas ferramentas e estratégias de compreensão dos textos em nível narrativo, ajudou a colocar em evidência o sentido que se sedimenta no conteúdo profundo desta obra: é o trabalho - e obviamente, o sujeito que o executa - a fonte de riqueza dos países que procuram prosperar através da lógica liberal tradicional.

Uma das conclusões é que o discurso praticado na obra é muito mais complexo e rico do que qualquer recorte que se faça em uma dissertação, tese, quanto mais em um capítulo final do presente trabalho.

Além disso, ainda que esta proposta de análise coloque o trabalhador na centralidade da lógica de mercado, e não o mercado em si - leia-se, lucros, juros e empreendedores - de maneira alguma desautoriza as demais conclusões acerca do pensamento liberal, sendo profícuo e necessário o debate sobre os sistemas econômicos no mundo, sobretudo da predominância do próprio capitalismo vigente em escala global.

A conclusão que fica é uma pequena proposta sobre um velho-novo paradigma do fazer econômico liberal clássico, graças ao prisma semiótico, em que este liberalismo difere razoavelmente do atual neo-liberalismo, transtornado e desenfreado, desde a sua eclosão em meados do século $\mathrm{XX}$, o qual provocou e provoca uma espécie de niilismo da figura subjetal extremamente importante para o discurso e o funcionamento da economia: o trabalhador.

Assim, talvez sejam necessárias outras diferentes leituras e análises, além de um retorno às bases dos pensamentos econômicos, não por conta de um apelo a um conservadorismo/ saudosismo acadêmico-epistemológico, mas pelo presente momento crítico e complexo pelo qual o país passa. 
Momento este apinhado daqueles que verborragizam gratuitamente "mão invisível", "tempo é dinheiro" como mantras de um dogmatismo "pró-mercado" e que ora se aproveitam de um conceito interpretado, quando muito, pelas vias da insensatez, ora por se valerem mesmo das más intenções veladas, disfarçadas por políticas públicas, quando não corruptas, néscias e ineficientes.

Sem incorrer numa empáfia ou coisa do tipo, ao se deparar com os resultados desta análise, que o ferramental semiótico nos traz para um melhor entendimento do papel desse trabalhador da obra smithiana, percebe-se o quanto os mais ditos capitalistas (liberais?), geralmente detentores de grande poder de cunho privado/público, são justamente os que pouco respeitam e refletem sobre os fundamentos do pensamento liberal e do bem comum, das camadas mais necessitadas, camada essa formada pela mão de obra da nação, e que justamente delas dependem, ratificando o quão narrativamente e profundamente nada entendem das bases do sentido colocado pela teoria econômica que mais se inflamam quando a conhecem! - ao proferir.

Como demonstrada pelo regime da atribuição e apropriação do objeto pelo sujeito, não se trata de um jogo de soma zero, senão um jogo em que todos ganham, e outros ganham mais ainda, oras, nada mais justo - no sentido de adequação - e coeso à filosofia liberal.

Por fim, para que não se deposite a conta desta crítica simplória na conclusão de uma dissertação de mestrado, deixo falar o próprio autor, do capítulo VIII, Os salários do trabalhador:

Dever-se-á considerar esta melhoria da situação das camadas mais baixas da sociedade como uma vantagem ou como um inconveniente para a sociedade? A resposta é tão óbvia, que salta à vista. Os criados, trabalhadores e operários dos diversos tipos representam a maior parte de toda grande sociedade política. Ora, o que faz melhorar a situação da maioria nunca pode ser considerado como um inconveniente para o todo. Nenhuma sociedade pode ser florescente e feliz, se a grande maioria de seus membros forem pobres e miseráveis. Além disso, manda a justiça que aqueles que alimentam, vestem e dão alojamento ao corpo inteiro da nação, tenham uma participação tal na produção de seu próprio trabalho, que eles mesmos possam ter mais do que alimentação, roupa e moradia apenas sofrível. (SMITH, [1776] 1996, p. 128). 


\section{BIBLIOGRAFIA}

BARROS, D. L. P. Teoria do discurso: fundamentos semióticos. $3^{\text {a }}$ ed. São Paulo: Ed. Humanitas, 2002.

Teoria semiótica do texto. $4^{\mathrm{a} e d . ~ S a ̃ o ~ P a u l o: ~ E d . ~ A ́ t i c a, ~} 2005$.

BENVENISTE, Émile. Problemas de Linguística Geral I. [1976] Trad: Maria da Glória Novak e Maria Luisa Neri. 5 Ed. Campinas, São Paulo: Pontes Editores, 2005.

BERTRAND, Denis. Caminhos da semiótica literária. São Paulo: EDUSC, 2003.

CONWAY, Edmund. 50 ideias de economia que você precisa conhecer [2009].

Tradução Marcello Borges. 1 Ed. São Paulo: Planeta, 2015.

FIORIN, J. L.; Elementos de análise do discurso. 14ed. 2a reimpressão. São Paulo: Contexto, 2009.

FONTANILlE, Jaques. Semiótica do Discurso. Tradução: Jean Cristtus Portela. $2^{\text {a }}$ Ed. São Paulo: Contexto, 2015.

GREIMAS, A. J. [1970] Sobre o sentido: ensaios semióticos. Trad: Ana Cristina Cruz Ceszar et al. São Paulo: Ed. Vozes, 1975.

[1983] Sobre o sentido II: ensaios semióticos. Trad: Dilson Ferreira da Cruz. 1 Ed. São Paulo: Edusp, 2014.

[1975] Semiótica e ciências sociais. Trad: Álvaro Lorencini e Sandra Nitrini.

São Paulo: Ed. Cultrix, 1981

; COURTÉS, J. Dicionário de semiótica. [1986] Ed. São Paulo: Contexto, 2008.

HJELMSLEV, Louis [1943]. Prolegômenos a uma teoria da linguagem. Trad. J. Teixeira Coelho Netto. São Paulo: Perspectiva, 2006.

JESSOP, B. Análise Semiótica Crítica e Economia Política Cultural. Liinc em Revista, Rio de Janeiro, v.6, n.2, setembro, p. 197-213, 2010, disponível em http://www.revista.ibict.br/liinc Acesso em: 07/05/2017.

KHUN, T. S. [1962] A estrutura das revoluções científicas. Trad.: Beatriz Viana Boeira e

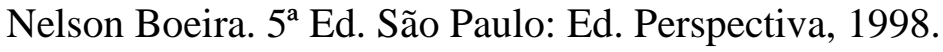

KOTLER, P.; ARMSTRONG, G. Princípios de Marketing. Rio de Janeiro: LTC, 1997.

LAUDAN, Larry. [1977] O progresso e seus problemas. Tradução: Roberto Leal Ferreira. São Paulo: Ed. UNESP, 2011. 
LOPES, Edward. A Identidade e a Diferença: raízes históricas das teorias estruturais da narrativa. São Paulo: EDUSP, 1997.

LOPES, I. C.; HERNANDES, N. (org.) Semiótica: objetos e práticas. São Paulo: Ed. Contexto, 2005.

MACEDO, J. A. O. Conflitos de competência na tributação do consumo, 2013, 81 f., tese, (doutorado em direito econômico e financeiro) - Faculdade de Direito, São Paulo, 06/10/2013. Disponível em: < http://www.teses.usp.br/teses/disponiveis/2/2133/tde09012014-115232/pt-br.php> Acesso em Fevereiro de 2017.

MARX, K. [1853] A companhia das Índias Orientais: sua história e as consequências de sua atividade. New-York Dayle Tribune. New York. 24 de Junho de 1853. Tradução: Jason Borba. (https://www.marxists.org/archive/marx/works/1853/07/11.htm). Recuperado de <http://www.dominiopublico.gov.br/download/texto/ma000034.pdf $>$ Acesso em Junho de 2019.

MARX, K. [1867] O capital: crítica da economia política. Livro I. Tradução: Rubens Enderle. São Paulo, Ed. Boitempo. PDF. Recuperado de

http://www.gepec.ufscar.br/publicacoes/livros-e-colecoes/marx-e-engels/o-capital-livro1.pdf/at_download/file

MATTOS, L. V. As razões do laissez-faire: uma análise do ataque ao mercantilismo e da defesa da liberdade econômica na Riqueza das Nações Revista de Economia Política, vol. 27, $n^{o} 1$ (105), pp. 108-129, janeiro-março/2007. Disponível em:

$<$ http://www.rep.org.br/all_issue.asp > Acesso em Janeiro de 2019.

Natural e Instituições Revista Estudos Econômicos da Universidade de São Paulo, v. 37, n. 3, p. 635-662, JULHO-SETEMBRO 2007. Disponível em:

<https://www.revistas.usp.br/ee/issue/view/2942> Acesso em Janeiro de 2019.

PORTELA, Jean Cristtus. Semiótica midiática e níveis de pertinência. Itália. In: DINIZ, M. L. V. P.; PORTELA, J. C. (org.). Semiótica e Mídia: textos, práticas, estratégias. $1^{\mathrm{a}}$ Ed. Bauru: UNESP/FAAC, 2008. Capítulo 1, p. 96-115.

SANDRONI, Paulo. Novíssimo dicionário de economia. 3. Ed. São Paulo: Circulo do Livro, 1999.

SANTOS, A. T. L. A; BIANCHI, A. M. Além do Cânon: Mão Invisível, Ordem SAUSSURE, Ferdinand de [1916]. Curso de linguística geral. [trad. Antônio Chileno, José Paulo Paes e Isidoro Blikstein] São Paulo: Editora Cultrix, 2006.

SMITH, Adam [1776]. A riqueza das nações: investigação sobre a natureza e suas causas. Vol. I. Tradução: Circulo do Livro ltda. São Paulo: Abril Cultural, 1996. Coleção Os Economistas.

[1776]. A riqueza das nações: investigação sobre a natureza e suas causas.

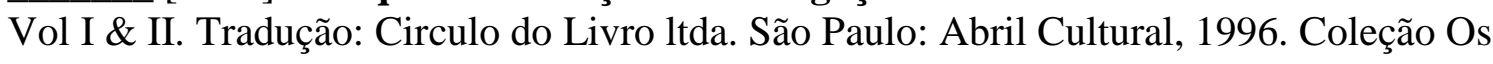


Economistas. Disponível em:

https://www.google.com.br/url?sa=...EconomistaAdam_Smith acesso em Julho de 2017.

[1776]. An inquiry into the nature causes of the wealth of nations.

SmithA_WealthNations. Metalibri, 2007. PDF. Recuperado de

https://www.ibiblio.org/ml/libri acesso em Julho de 2017.

Fontes, 1999.

[1759]. Teoria dos Sentimentos Morais. Tradução: Lya Luft. São Paulo: Martins

SOUSA, P.M.; 2016, 277f., tese (doutorado em semiótica e linguística geral) - Faculdade de Filosofia, Letras e Ciências Humanas, São Paulo, Disponível em:

$<$ https://www.teses.usp.br/teses/disponiveis/8/8139/tde-15082016-

120723/publico/2016_PaulaMartinsDeSouza_VCorr.pdf> Acesso em Maio de 2019.

SOWELL, Thomas [2007]. Conflito de visões: origens ideológicas das lutas políticas.

Trad.: Margarita Maria Garcia Lamelo. São Paulo: Ed. É Realizações, 2012.

TATIT, Luiz. Análise semiótica através das letras. São Paulo: Ateliê Editorial, 2001.

Semiótica à luz de Guimarães Rosa. São Paulo, Ateliê Editorial, 2010.

TOMASI, Carolina. Elementos de semiótica: por uma gramática tensiva do visual. 1 ed. São Paulo: Atlas, 2012.

ZILBERBERG, C. Razão e poética do sentido. Tradução: Ivã Lopes; Luiz Tatit; Waldir Beividas. São Paulo: EDUSP, 2006. 